UNITED STATES DEPARTMENT OF THE INTERIOR

Harold L. Ickes, Secretary

GEOLOGICAL SURVEY

W. C. Mendenhall, Director

\title{
Bulletin 885
}

\section{GEOLOGY AND ORE DEPOSITS \\ OF THE LORDSBURG MINING DISTRICT HIDALGO COUNTY, NEW MEXICO}

\author{
BY \\ SAMUEL G. LASKY \\ Prepared in cooperation with the \\ STATE BUREAU OF MINES AND MINERAL RESOURCES \\ NEW MEXICO SCHOOL OF MINES
}

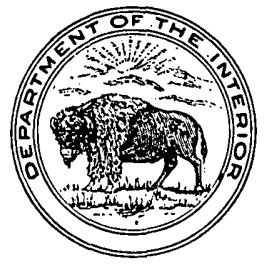

UNITED STATES

GOVERNMENT PRINTING OFFICE

WASHINGTON : 1938

For sale by the Superiutendent of Documents, Washington, D. C. - - - Price \$1.25 (Paper) 



\section{CONTENTS}

Page

Abstract_. _.

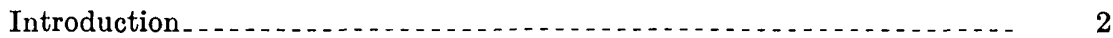

Scope of the report

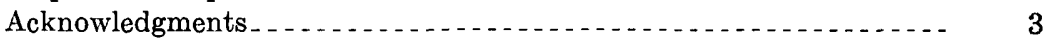

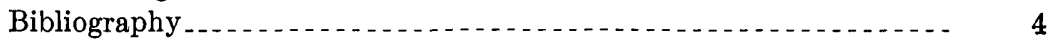

Geography _... 5

Location of the district.......... 5

Climate and vegetation $\ldots \ldots \ldots$

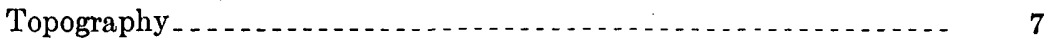

Surface and underground waters.

Geology _...

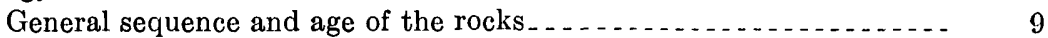

Earlier (Lower Cretaceous) volcanic rocks _................ 11.

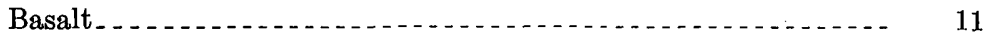

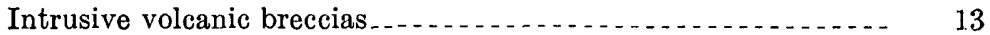

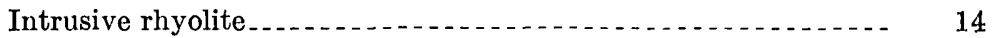

Late Cretaceous or early Tertiary intrusives......... 14

Porphyritic granodiorite........ 14

Granodiorite porphyry and aplite dikes $\ldots \ldots \ldots \ldots$

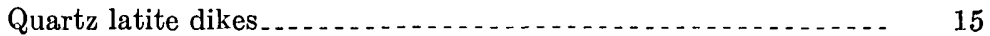

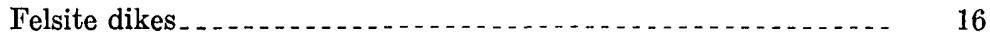

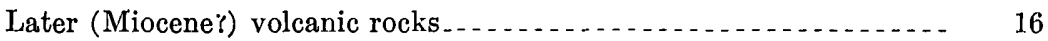

Structure _._.

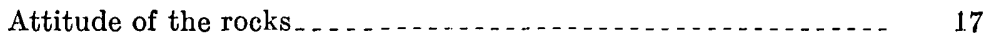

Faults_...

Interpretation of geologic history

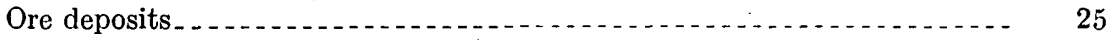

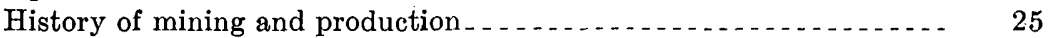

Form and structure of the deposits $\ldots \ldots \ldots$

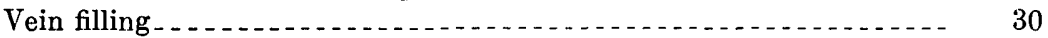

General features... 30

First stage of mineralization .

Second stage of mineralization _.

Hydrothermal leaching _.

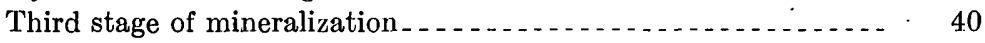

Fourth and fifth stages of mineralization . . . . . . . . . 40

Sixth stage of mineralization

Oxidation and enrichment.

Future operations in the Lordsburg district. . . . . . . . . . . 42

The mines.

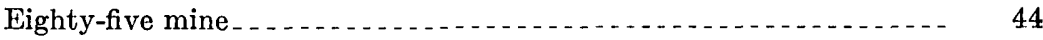

General features......

Geologic relations . $\ldots \ldots \ldots$

Ore deposits .

Continuation of ore beyond known limits 
The mines-Continued. $\quad$ Page

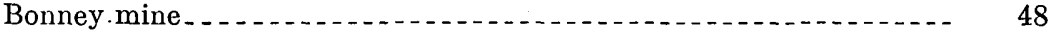

Location .

History and production.

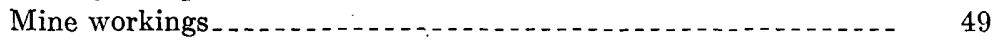

Geology and ore deposits

Future prospecting

Anita mine.................. 51

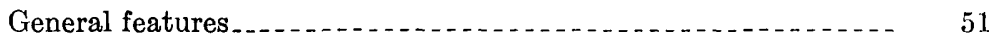

Geology and ore deposits............ 51

Atwood (Alamo) mine. . .

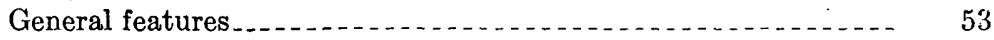

Geology and ore deposits.............. 53

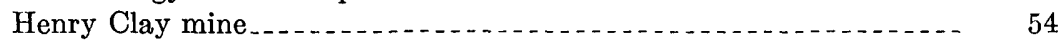

Misers Chest (Lena) mine _........ 55

Leitendorf camp (Pyramid district) $\ldots \ldots$

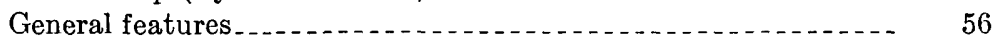

History and production

Geology and ore deposits . .

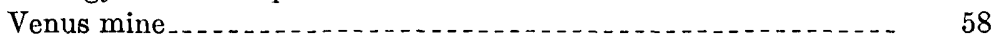

Last Chance mine .

Nellie Bly and Robert E. Lee mines...... 59

Index . . . . . . . . . . .

\section{ILLUSTRATIONS}

Plate 1. Geologic map and sections of the north end of the Pyramid Mountains, Hidalgo County, N. Mex....................

2. $A, B$, Aerial photograph, with explanation, of main part of the

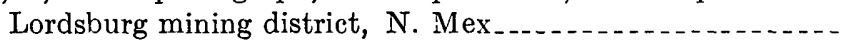

3. Geologic map and sections of the Lordsburg mining district, Hidalgo County, N. Mex _.................................

4. $A$, Volcanic necks extending above the alluvium south and east of Gary siding; $B$, Steeply dipping bedded rhyolite breccia capping hill northeast of Aberdeen Peak .................

5. Outline map and sectionalized isometric diagram of the Lordsburg district, N. Mex., showing relation of faults and veins to the granodiorite stock

6. Close view of one of the prominent quartz outcrops typical of the Anita-Atwood group of veins. . . . . . . . .

7. View looking westward toward Lee Peak along the Florence May-Lone Star-Summit vein

8. $A$, Photomicrograph of tourmalinized granodiorite; $B$, Drusy breccia ore from the Eighty-five mine.................

9. Breccia ore from which most rock fragments have been leached_

10. $A$, Fine-textured honeycomb of quartz, specularite, and chalcopyrite; $B$, Porous "worm-eaten" chalcopyrite and sphalerite.

11. Photomicrographs of altered rocks: $A$, Chloritized, sericitized

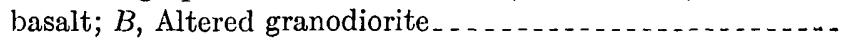

48

8

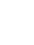

9

1

1

3

3

4

6

6

6

8

8


Plate 12. $A$, Honeycombed ore coated with quartz and chalcopyrite; B, Specimen of ore from the Eighty-five mine showing first
three stages of mineralization B, Specimen of ore from the Eighty-five mine showing first
three stages of mineralization

Page ing vertical projection of the Eighty-five vein .......... In pocket

14. Claim map of the Lordsburg mining district............. 42

15. Geologic plans of the $650-; 1,050$-, and 1,500-foot levels of the Eighty-five mine and surface geology along the outcrop. In pocket

16. Geologic sections through the Eighty-five mine........... 50

17. Plan and projection of the Bonney mine

18. Geologic sections of the Bonney mine

19. Geologic plan of the fifth level of the Bonney mine........ 50

20. Plan and projection of the Anita mine........... In pocket

21. Geologic sections of the Anita mine................. 50

22. Geologic plans and section of the Atwood mine ........... 58

23. Geologic level maps of the Misers Chest mine........... 58

24. Plan and vertical projection of the Last Chance mine........- 58

25. Plan and section of the Nellie Bly mine.................. 58

Figure 1. Map of New Mexico and eastern Arizona, showing location of the Lordsburg mining district................ 6

2. Sketch map of the intrusive breccia at Atwood Hill........ 13

3. Map of the northern horn of the granodiorite stock ...... 19

4. Direction and amount of dip of the faults of the Lordsburg mining district.

5. Similar fault patterns formed by shearing couples acting in the same planes but in opposite directions. 23

6. Details of veins in the Lordsburg mining district......... 31

7. Drusy breccia ore, Lordsburg mining district. 32

8. Mineral succession in the Lordsburg mining district and the relation of mineral deposition to other events.

9. Variations in aggregate length of stoping ore on the different levels of the Eighty-five mine to the 1,650-foot level....... 



\title{
GEOLOGY AND 0RE DEP0SITS 0F THE LORDSBURG MINING DISTRICT, HIDALGO COUNTY, NEW MEXIC0
}

\author{
By Samuel G. Lasky
}

\begin{abstract}
The Lordsburg copper-mining district occupies the low pyramidal hills that form the northern part of the Pyramid Mountains, immediately southwest of Lordsburg, N. Mex.

From 1904 to 1933 the Lordsburg district produced 1,671,669 tons of ore containing copper, gold, silver, and lead valued at $\$ 19,482,671$ and was one of the most productive districts in New Mexico. Mining activity depended almost entirely upon an unusual demand for siliceous fluxing ore like that of the Lordsburg district, and it ended abruptly with a cessation of this demand in 1931 . Resumption of mining is dependent on increased metal prices or on a renewed demand for fluxing ore by the copper smelters.

The oldest rocks exposed in the Lordsburg district are basalt flows, of Comanche (Lower Cretaceous) age, at least 2,000 feet thick, intruded by plugs of basalt and rhyolite breccias and by plugs of white rhyolite. Interbedded breccia and thin flows derived from some of the breccia plugs are present here and there. An irregular, horseshoe-shaped stock of granodiorite and related dikes of granodiorite porphyry and aplite intrude the volcanic rocks. The cover has barely been removed from the northern part of the stock, and the present topography there gives a general picture of the original surface of the mass. Roof pendants in the stock and outliers of granodiorite bordering it are common. The border of the stock shows evidence of assimilation of basalt on a small scale, and the adjacent basalt is metamorphosed locally to a rock mineralogically like the granodiorite. Plugs and dikes of quartz latite and dikes of white felsite cut the granodiorite and earlier rocks, and Miocene (?) lavas and associated breccias and tuffs, later than the quartz latite dikes, are extensively exposed south of the district, where they are separated from the other rocks by a major unconformity.

The faults of the district fall roughly into two sets, one trending eastward and the other northeastward. They seem to be confined largely to zones that follow the general outline of the stock, which possibly acted as a bulwark against the stresses, presumably regional, that produced the faults. Nearly all faults originated prior to the period of ore formation, and they furnished the channels for the ore-bearing solutions. A few faults, either barren of vein matter or containing only a small quantity of the latest minerals, offset the veins slightly. At least seven stages of movement have been recognized. The direction and amount of movement are generally indeterminable, but it is known that the net displacement of all recurrent movements along the northeastward-trending Emerald fault, one of the most persistent in the district, is nearly horizontal and hardly exceeds 150 feet. The pattern of the eastwardtrending Anita-Atwood fault zone suggests that the main members of that zone also may have had essentially horizontal movement.
\end{abstract}


The rein filling was deposited during the general period of faulting, but each reopening of the fissure was accompanied by a change in the character of the material deposited, and consequently there were six distinct stages of mineralization. At no stage except possibly the first were the vein openings filled completely, and the composite filling is generally a highly vuggy and drusy mass.

The deposits belong to the copper-tourmaline type, and the Emerald vein, which has been mined continuously for a vertical depth of 1,900 feet and has yielded about 1,500,000 tons of ore, contained the most productive deposit of this type in the United States. The average hypogene ore in this deposit contained 2.8 percent of copper and 1.23 ounces of silver and 0.111 ounce of gold to the ton. A characteristic feature of the deposits is the occurrence of ore in overlapping segments.

The six stages of activity during mineralization were as follows:

1. Formation of sericite, chlorite, and calcite in the wall rocks, local impregnation of the wall rocks by tourmaline and specularite, and deposition of tourmaline and specularite in the vein openings.

2. Reopening of the veins with some sheeting and brecciation, followed by deposition of quartz and a little pyrite, which were accompanied at first by a trace of chlorite, then by considerable coarse-grained chalcopyrite and a little manganosiderite, and still later by sphalerite and minor amounts of galena and barite. Wall-rock alteration consisted chiefly of sericitization and silicification, which partly destroyed the earlier tourmaline and specularite, but the specularite seems to have been comparatively stable in the presence of the sulphidedepositing solutions. The exploitable ore deposits were formed during this stage; minor amounts of valuable metals were added during other stages, but dilution by valueless gangue more than offset this gain.

3. Reopening and further brecciation, starting possibly near the galenabarite phase of deposition and providing access for the third-stage solutions. These solutions at first dissolved the sericite, chlorite, and calcite from residual wall rock in the veins, leaving behind honeycombed masses of first- and secondstage minerals. Subsequent third-stage deposition consisted of abundant finegrained drusy quartz, a very little chalcopyrite and pyrite, and a trace of chlorite.

4. Reopening, followed by partial cementation by pink manganiferous calcite, which is most abundant as "dogtooth spar" lining large cavities that resuited from leaching or flushing out of fault gouge and breccia. Locally the calcite is accompanied by minor chalcopyrite and galena.

5. Reopening, followed by deposition of calcite only.

6. Deposition of minor amounts of quartz, calcite, and fluorite, and alteration of the quartz latite dikes, which were injected between this and the preceding stage.

Supergene alteration of the ores is irregular. High-grade supergene ores of gold and copper have been mined, but enrichment at one place by either of these metals was balanced largely by leaching at another. The average silver content, on the contrary, was almost trebled by supergene enrichment.

\section{INTRODUCTION}

\section{SCOPE OF THE REPORT}

The Lordsburg copper-mining district, in Hidalgo County, southwestern New Mexico, was selected in 1930 for study by the United States Geological Survey in cooperation with the New Mexico Bureau of Mines and Mineral Resources. At that time the district was the 
third most productive district in New Mexico, as the result of mining on a large scale at the Eighty-five mine to supply the company's smelter in Arizona with siliceous fluxing ore. Other smelters handling ores from New Mexico were also in need of such ore, and in view of this demand it was believed that a detailed geologic survey would be of current benefit to the general mining industry of the State as well as to the district itself. A special topographic base map was prepared by the United States Geological Survey in 1981, but before the geologic study could be started it became known that the Eighiy-five was to be closed by the end of the year and that the smaller mines also would probably be closed because of the depressed condition of the copper industry. The writer visited the district as soon as possible thereafter and mapped the geology of the mines in detail while the workings were still accessible. He was engaged in other work after this visit, and before he could resume work in the Lordsburg district it began to appear that the depressed condition of the industry was likely to be of long duration and that therefore a study of the district was no longer of current importance. Much information had been obtained in the course of underground mapping, however, and it was decided to complete the survey, though in less detail than originally planned, so that this information could be appraised and made available.

Surface mapping in the district was carried on in November and December 1933. The main part of the district, embracing about 12 square miles, was mapped on a scale of $1: 24,000$. In addition, about 40 square miles of the surrounding area was mapped on a scale of $1: 48,000$ in order to correlate the geology in the vicinity of the mines with that of the adjacent country, particularly with the geology of the old silver camp at Leitendorf (Pyramid), to the south. (See pl. 1.)

The cooperative agreement between the Federal Survey and the New Mexico Bureau of Mines and Mineral Resources was extended in 1934 to permit a geologic survey of the whole of Hidalgo County, and it was hoped that this regional study would lead to a solution of several important problems, including the depth at which the ores were formed and the origin of the ore-bearing fissures, for which the evidence within the Lordsburg district alone is insufficient.

\section{ACKNOWLEDGMENTS}

The writer has thanked directly many of his friends at Lordsburg and in the Lordsburg mining district who were of assistance in his work, and he wishes to take this opportunity to thank the many others whom it is not possible to reach otherwise. The officials of the different properties were generous in their cooperation; particular mention should be made of A. J. Balmforth, superintendent, and R. B. Youtz, 
chief engineer, of the Eighty-five mine; E. O. Binyon, superintendent of the Anita mine; J. B. Foster, owner of the Bonney mine; J. L. Augustine, co-owner, and John Brooks, superintendent, of the At-. wood (Alamo) mine; and O. E. Mikesell, owner of the Phoenix group of claims.

B. S. Butler, of the United States Geological Survey, spent 2 days in the field with the writer in 1931, and the suggestions he made at the time were extremely valuable in guiding the later work. Special thanks are due to E. H. Wells, Director of the New Mexico Bureau of Mines and Mineral Resources, at Socorro, who generously placed all facilities of the Bureau at the writer's disposal during the preparation of this report.

\section{BIBLIOGRAPHY}

The following publications contain information on the geology and mining industry of the Lordsburg mining district.

1856. Antisell, Thomas, Geological report: U. S. Pacific R. R. Expl., vol. 7, pp. 152-154. A geologic reconnaissance in connection with the expedition of Lt. J. G. Parke to survey a railroad route from the Gila River to the Rio Grande, near the $32 d$ parallel.

1875. Gilbert, G. K., The geology of portions of Arizona and New Mexico: U. S. Geog. and Geol. Surveys, W. 100th Mer. Rept., vol. 3, pp. 503-567. A geologic reconnaissance made in connection with the Wheeler Survey. Contains observations on the geology along the route previously reconnoitered by Antisell, including a general description of the Virginia subdistrict.

1881-83. Burchard, H. C., Report of the Director of the Mint for 1881, pp. 332333 ; idem for 1882, pp. 361-365; idem for 1883, pp. 588-590. These reports contain considerable historical information and excellent summaries of the status of the district at that time. They include also detailed descriptions of many of the mines.

1902-3. Otero, M. A., Report of the Governor of New Mexico to the Secretary of the Interior for 1902 , p. 510 ; idem for 1903, pp. 71-72. Comments on the history of the district and lists of the properties then active.

1904. Jones, F. A., New Mexico mines and minerals, pp. 58-61, Santa Fe. An account of the discovery and early history of the Virginia and Pyramid subdistricts, with notes on the mines then in operation.

‘907. Jones, F. A., The Lordsburg mining region of New Mexico: Eng. and Min. Jour., vol. 84, pp. 444-445. Includes an account of the discovery and early history of the area, a short description of the geology and of the ore deposits as then known, and a sketch map showing the location of the principal mines and prospects.

1910. Lindgren, Waldemar, Graton, L. C., and Gordon, C. H., The ore deposits of New Mexico: U. S. Geol. Survey Prof. Paper 68, pp. 332-335. Includes a reconnaissance study of the geology and ore deposits of the Lordsburg district with descriptions of the mines as developed in 1905.

1918. Schwennesen, A. T., Ground water in the Animas, Playas, Hachita, and San Luis Basins, N. Mex.: U. S. Geol. Survey Water-Supply Paper 422. A study of the ground-water supply in the desert flats surrounding the Pyramid and adjacent ranges. Includes a complete description of the Quaternary deposits but only casual mention of the pre-Quaternary rocks of the Pyramid Mountains. 
1922. Finlay, J. R., Report of appraisal of mining properties of New Mexico, 1921-22, Santa Fe, New Mexico State Lax Commission. Gives data on the Eighty-five and Bonney mines.

1931. Youtz, R. B., Mining methods at the Eighty-five mine, Calumet \& Arizona Mining Co., Valedon, N. Mex.: U. S. Bur. Mines Inf. Circ. 6413. Contains a description of the geology of the mine and data on its history and production.

1.933. Lasky, S. G., and Wootton, T. P., The metal resources of New Mexico and their economic features: New Mexico School of Mines, State Bur. Mines and Mineral Resources, Bull. 7, pp. 71-74. Contains a preliminary description of the Lordsburg area.

1935. Lasky, S. G., Igneous assimilation and associated contact metamorphism in the Virginia mining district, New Mexico: Am. Mineralogist, vol. 20, pp. 552-561. A more detailed description and discussion than is given in the present report.

1935. Lasky, S. G., The Lordsburg district, New Mexico, in Copper resources of the world, pp. 337-341, 16th Internat. Geol. Cong. A preliminary description of the ore deposits and a brief sketch of the geology, based on the writer's visit in 1931. (See p. 3 of the present report.)

1936. Lasky, S. G., Hydrothermal leaching in the Virginia mining district, New Mexico: Econ. Geology, vol. 31, pp. 156-169. Contains a more detailed discussion of the nature of the leaching solutions than is given in the present report.

1905-36. Annual volumes of Mineral Resources of the United States, published until 1923 by the U. S. Geological Survey and since then by the U. S. Bureau of Mines. Published as the Minerals Yearbook since 1982. Each volume gives a brief review of mining activities for the year treated, including production statistics and notes on the character of the ore mined. In volumes prior to 1920 references to the Lordsburg district appear under Grant County.

\section{GEOGRAPHY}

\section{LOCATION OF THE DISTRICT}

The Lordsburg mining district is in the northern part of Hidalgo County, N. Mex., and lies southwest of the town of Lordsburg, about 17 miles east of the Arizona line. (See fig. 1.) Lordsburg, which had a population of 2,026 in 1930, is a division point on the main line of the Southern Pacific Railroad and is on United States Transcontinental Highway 80. A branch line of the railroad connects Lordsburg with the town of Valedon, 3 miles southwest, in the heart of the Lordsburg district, where the offices and shops of the Eightyfive mine were located.

The district is in the extreme northern part of the Pyramid Mountains, which extend from a line 11/2 miles north of Valedon southward for about 21 miles. It includes two contiguous subdistricts-the Virginia district, occupying that part of the range north of the Lordsburg-Animas road and covering about 20 square miles, and the Pyramid (Leitendorf) district, occupying the area of 2 or 3 square miles south of the road and north of the Leitendorf Hills and the foot of North Pyramid Peak. 


\section{CLIMATE AND VEGETATION}

The climate and vegetation of the Lordsburg district are typical of the arid regions of the southwestern United States. Mesquite, several varieties of cactus, and the hardy creosote bush are the common plants. Grama grass, of several species, is sparsely distributed and barely suffices to support the few herds of goats that are pastured in the area. The average annual temperature at Lordsburg

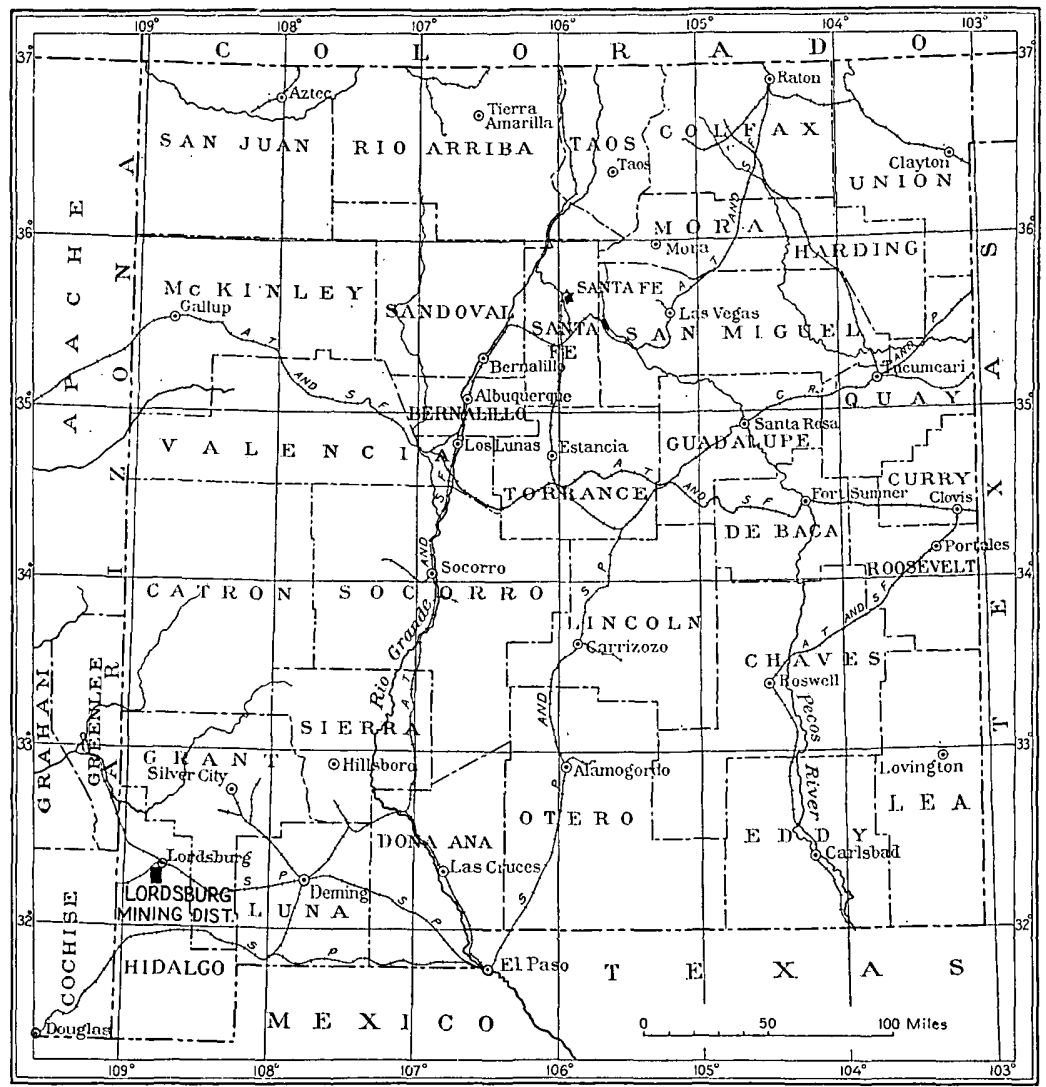

Fladre 1.-Map of New Mexico and eastern Arizona, showing location of the Lordsburg mining district.

ranges from $60^{\circ}$ to $62^{\circ} .{ }^{1}$ Temperatures above $100^{\circ}$ are common in June, July, and August, but the nights are usually comfortable, the minimum temperature during those months averaging about $50^{\circ}$. During the winter the average temperature is $44^{\circ}$ to $46^{\circ}$, the thermometer falling to $0^{\circ}$ or slightly below for short intervals of time. The average annual precipitation over a period of 46 years was 9.14 inches. The heaviest rains usually fall in July and August in

\footnotetext{
1 Linney, C. E., Garcia, Fabian, and Hollinger, E. C., Climate as it affects crops and ranges in New Mexico: New Mexico Coll. Agr. and Mech. Arts, Agr. Exper. Sta., Bull. 182 , p. $31-32,1930$. Also records of the U. S. Weather Bureau.
} 
thunderstorms of short duration, the precipitation during those months averaging nearly 40 percent of the yearly total. A minor wet season occurs during the cold months. Snowfalls are rare and ephemeral.

\section{TOPOGRAPHY}

The Pyramid Mountains form one of the isolated ranges typical of the high desert plateau that constitutes this part of the United States and that is characterized by sharply marked, narrow mountain ranges separated by wide valleys, or basins, filled by wash from the mountains. In this part of New Mexico the mountain ranges trend northward and cover about a third of the area. The Pyramid Range lies within the closed Animas drainage basin; it is limited on the west by the Animas Valley and on the east by the Lordsburg Valley, which drains around the north end of the range and into the alkali flat or "dry lake" of lower Animas Valley.

The Pyramid Mountains were so named by Antisell ${ }^{2}$ because of the pyramidal appearance of the principal peaks and hills. The highest points are North (Big) Pyramid Peak, 6,002 feet above sen level, in the north-central part of the range, and South (Little) Pyramid Peak, 5,910 feet above sea level, in the southern part. The average altitude of the adjacent Lordsburg and Animas Valleys is about 4,200 feet.

Topographically the range is sharply divided into two parts-the low hills north of Leitendorf camp and the jumble of naked peaks and ridges to the south that make up the larger part of the range. The area of low hills constitutes the Lordsburg mining district. The hills are made up of comparatively soft rocks, and the highest points among them are the twin "pyramids" of Eighty-five and Lookout Hills, 5,105 feet and 4,975 feet respectively above sea level; Lee Peak, 5,022 feet; and Aberdeen Peak and the three adjoining hills to the southwest, the altitudes of which range from about 5,000 to 5,064 feet. In general, the hills have the appearance of a group of squat pyramids of different sizes, as shown in plate 2. The intervening gullies tend to follow contacts between different formations, and because many of the formations are intrusive, the drainage pattern is very irregular. At the edge of the hills erosion has become almost independent of the character of the rocks and has produced a late-stage desert topography in which irregular low spurs are separated by gravel-filled branching arroyos that extend well into the hills from all sides. (See pl. 1.) Some of the spurs have been cut off by the valley fill and now appear as detached hills bordering the main body. The spurs are largely graded rock sur-

2 Antisell, Thomas, Geological report: U. S. Pacific R. R. Expl., vol. 7, p. 152, 1856. 
faces that are part of a dissected pediment ${ }^{3}$ exposed for more than 2 miles from the foot of the hills.

Bold, wall-like ledges, locally called "quartz dikes", constitute a prominent feature of the topography. Lee Peak is formed by the intersection of several of these ledges. (See pls. 2 and 7.)

\section{SURFACE AND UNDERGROUND WATERS}

The Lordsburg district contains no streams nor springs. The arroyos become raging torrents immediately after summer cloudbursts, but they dry up within a few hours. The average water level in the hilly parts of the district normally ranges from 50 to about 550 feet below the surface, lying roughly at an altitude of about 4,400 feet. In the adjacent valleys the altitude of the water table decreases to about 4,130 feet, the depth below the surface ranging from 70 to 90 feet in Lordsburg Draw to less than 15 feet in Animas Valley.

The quantity of water that may be encountered in mining is not enough to handicap operations seriously. Pumping plants should be large enough, however, to take care of a flow much greater than the average, because large underground reservoirs may be tapped that for short periods may yield a flow of water several times as great as the normal flow. On April 4, 1929, when the Eighty-five mine was pumping about 350 gallons a minute, the south drift on the 1,650-foot level tapped a reservoir that at first yielded 800 gallons a.minute. The flow lessened a little after 15 hours, but the pumps were drowned and the water rose above the 1,350-foot level before new pumps could be installed. The flow from this underground pocket was measured at 103 gallons a minute after the 1,650-foot level was again unwatered. The following table gives an idea of the pumping capacity that must be provided in mining operations in the Lordsburg district.

Water pumped from mines in the Lordsburg mining district

\begin{tabular}{|c|c|c|c|}
\hline Mine & $\begin{array}{c}\text { Deepest } \\
\text { level }\end{array}$ & $\begin{array}{c}\text { Miles of } \\
\text { workings } \\
\text { below water } \\
\text { level (ap- } \\
\text { proximate) }\end{array}$ & $\begin{array}{l}\text { Water } \\
\text { pumped } \\
\text { (gallons a } \\
\text { minute) }\end{array}$ \\
\hline $\begin{array}{l}\text { Eighty-five } \\
\text { Do Do } \\
\text { Do Do } \\
\text { Anita } \\
\text { Atwood. } \\
\text { Bonney }\end{array}$ & $\begin{array}{r}1,650 \\
1,650 \\
1,650 \\
1,950 \\
800 \\
750 \\
620\end{array}$ & $\begin{array}{l}9 \\
9 \\
9 \\
10.5 \\
1.5 \\
.4 \\
1\end{array}$ & $\begin{array}{r}1350 \\
21,150 \\
3450 \\
450 \\
50-75 \\
1275 \\
115\end{array}$ \\
\hline
\end{tabular}

1 Before tapping the underground reservoir on the 1,650-foot level.

2 Immediately after tapping the underground reservoir on the 1,650-foot level.

3 After the early rush of water from the 1,650-foot level had slackened.

- The water pumped from the Eighty-five mine, after being discharged on the surface, passed across the course of the Atwood vein, and part of it may have seeped into the Atwood workings.

\footnotetext{
${ }^{3}$ Bryan, Kirk, Erosion and sedimentation in the Papago country, Arizona: U. S. Geol. Survey Bull. 730, pp. 52-65, 1923.
} 
Pumping at the Eighty-five mine, the workings of which extend 2,000 feet below the surface, seems to have artificially lowered the water table in the adjacent area to a considerable degree. For example, the water level at the Bonney mine, $1 \frac{11 / 2}{2}$ miles away on the same vein zone, was lowered from a depth of 190 feet in 1906 to 320 feet in 1927 and to 560 feet late in 1931, shortly before pumping at the Eighty-five mine was stopped. By the spring of 1933 the water level at the Bonney mine had dropped to 630 feet as the result of continued drainage into the dewatered area. This further lowering of the water table near the fringe of the dewatered area for at least a year and a half after pumping was stopped implies a very slow migration of ground water, and it may be a matter of years before the normal water table in that vicinity is fully restored. ${ }^{4}$ The general period was one of subnormal precipitation, but this could have accounted for only a small fraction of the lowering of the water level.

All water for domestic use is brought from wells at Lordsburg, as the mine waters are highly mineralized. The mine waters were used in steam boilers at the Eighty-five mine, but they had to be treated first. Future operations in the district may be confronted with similar problems, and analyses of some of the mine waters are therefore included here. The accompanying table shows the analyses of samples collected from the 650- and 750-foot levels of the Eightyfive mine when those were the lower levels of the mine. Samples from the 1,650- and 1,950-foot levels contained hydrogen sulphide and a little more than twice as much bicarbonate and calcium as the samples represented in the table.

Analyses of mine waters from the Eighty-five mine, Lordsburg mining district

[Parts per million]

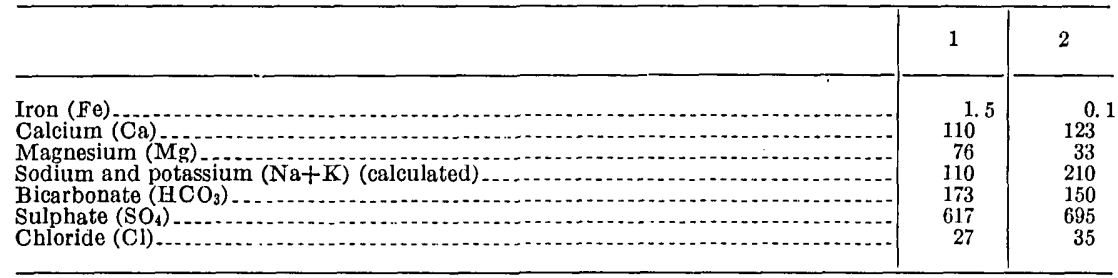

1. From 650-foot level (4,050 feet above sea level). Analysis furnished by Calumet \& A rizona Mining $\mathrm{Co}$. Sample taken November 1919. Analyst, The Permutit Co., New York.

2. From 750 -foot level ( 3,950 feet above sea level). Analysis furnished by Calumet \& $\Lambda$ rizona Mining $C_{0}$. Sample taken January 1921 .

\section{GEOLOGY}

\section{GENERAL SEQUENCE AND AGE OF THE ROCKS}

The exposed rocks of the Pyramid Mountains consist chiefly of volcanic necks, flows, and associated fragmental material belonging

4 On Sept. 23, 1935, water at the Eighty-five mine stood at an altitude of 4,100 feet, still about 300 feet below the normal water table. 
to two groups of different age and character. An irregular stock of porphyritic granodiorite intrudes the rocks of the earlier group within the Lordsburg district, and both the stock and the earlier rocks are cut by several varieties of dikes that are separated from the later volcanic rocks by a major unconformity. Magdalena (Pennsylvanian) limestone crops out at several places in the deeply eroded parts of the range south of the district.

The volcanic rocks of the younger group are part of the Tertiary (Miocene?) lava field of the Mexican Highland and of the southern volcanic lobe of the Colorado Plateau, but those of the older group are believed to be of Lower Cretaceous age. Several thousand feet of volcanic rocks of Lower Cretaceous age similar to those of the older group of the Pyramid Mountains and having similar age relations to intrusive bodies and to Tertiary volcanic rocks are present in the northern part of the Little Hatchet Mountains, the next range south. ${ }^{5}$ These Cretaceous volcanic rocks have been traced northward as far as the low hills southwest of Brockman, and it is almost certain that they and the earlier volcanic rocks of the Pyramid Mountains are parts of the same formation. The granodiorite stock of the Lordsburg district and the associated dikes, which are between the two lava groups in age, are therefore, presumably, late Cretaceous or early Tertiary. This is the age of many similar intrusive masses in the southwestern United States. The following table shows the sequence of the rocks and their chronologic relation to mineralization:

Formations in the Lordsburg mining district and in adjacent parts of the Pyramid Mountains

Pleistocene :

Stream gravel and valley fill.

Unconformity.

Miocene (?) :

Flows, volcanic necks, and associated dikes, forming the main part of the

Pyramid Mountains. Chiefly quartz latite.

Breccia and tuff:

Unconformity.

Late Cretaceous or early Tertiary:

Faint mineralization in the quartz latite dikes and in some veins.

Quartz latite dikes and plugs and felsite dikes.

Veins of commercial importance.

Aplite and granodiorite porphyry dikes.

Granodiorite stock.

Lower Cretaceous:

Intrusive white rhyolite, forming volcanic necks.

Intrusive rhyolite breccia, filling volcanic vents, chiefly those occupied by the earlier basalt breccia. The extrusive equivalent of this rock is present locally.

${ }^{5}$ Lasky, S. G., Geology and ore deposits of the Iittle Hatchet Mountains, N. Mex.: U. S. Geol. Survey Bull. - (in preparation). 


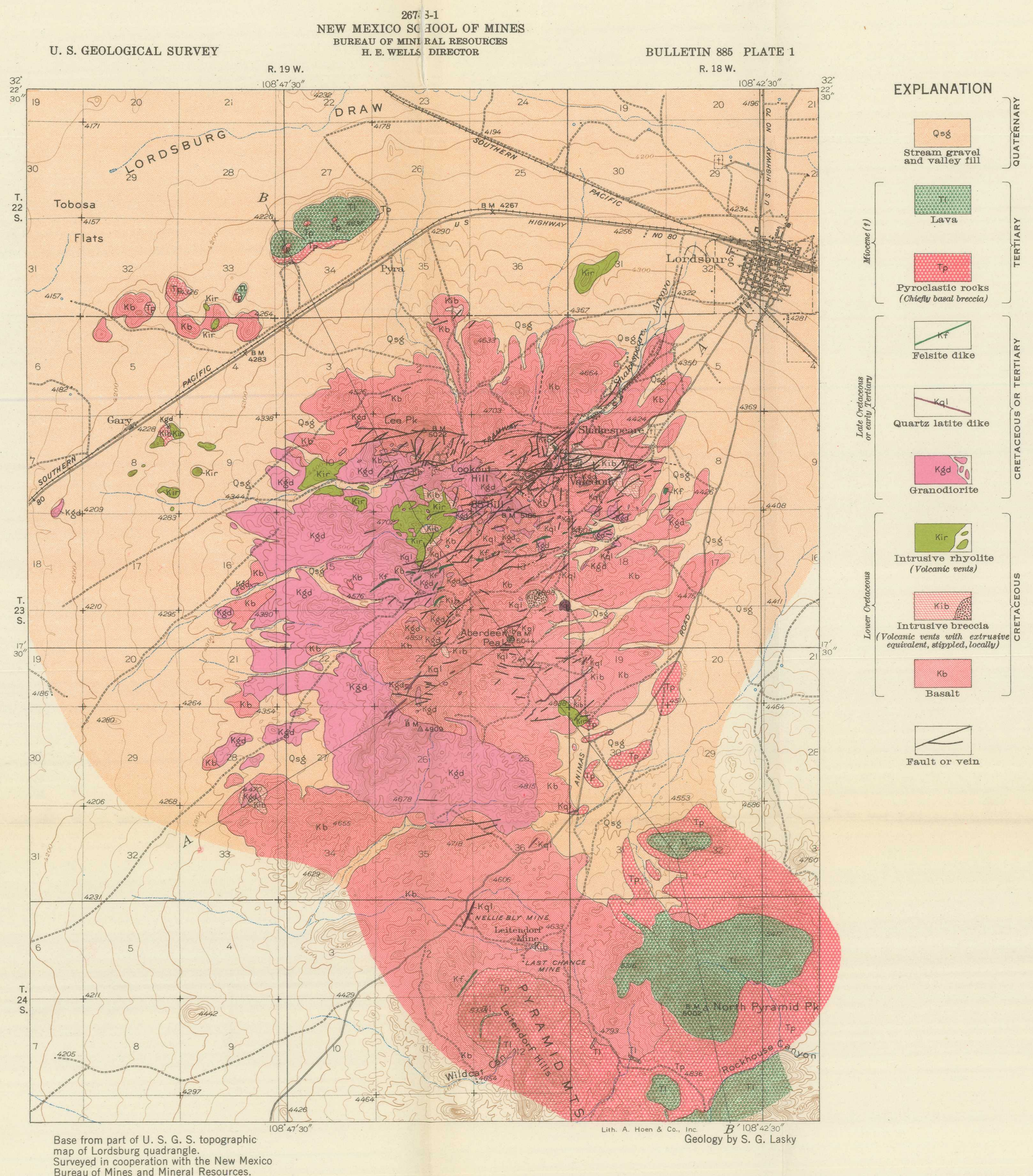

政
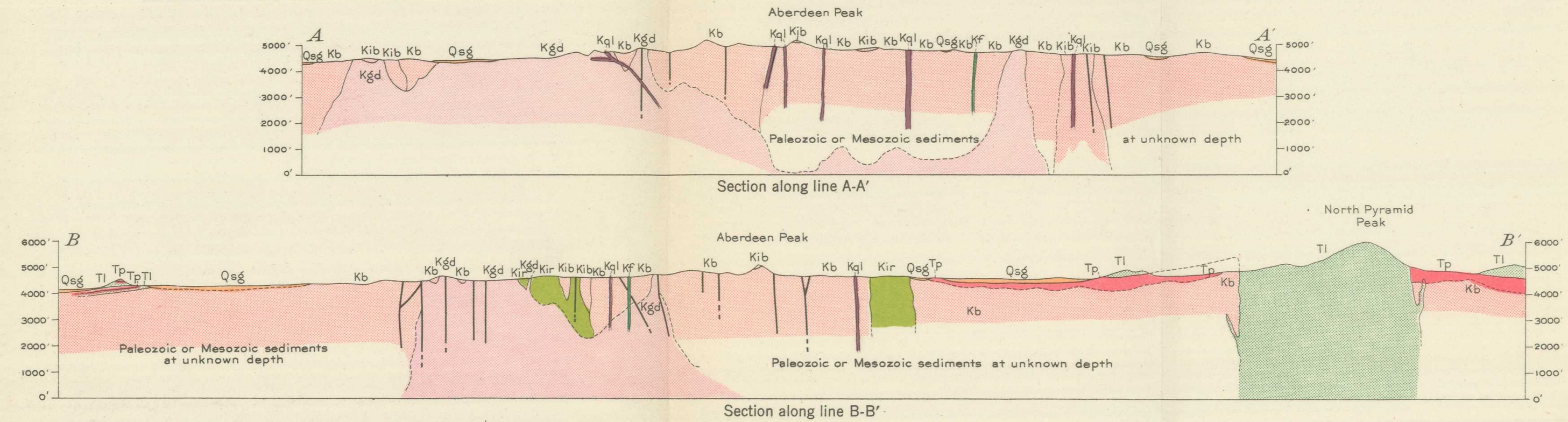

GEOLOGIC MAP AND SECTIONS OF THE NORTHERN END OF THE PYRAMID MOUNTAINS, HIDALGO COUNTY, N. MEX.

Note:- At top of plate the name
should be E. H. Wells.

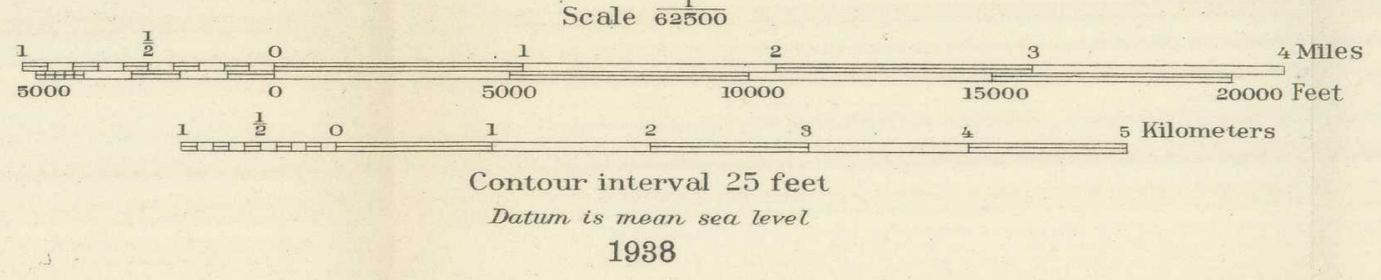




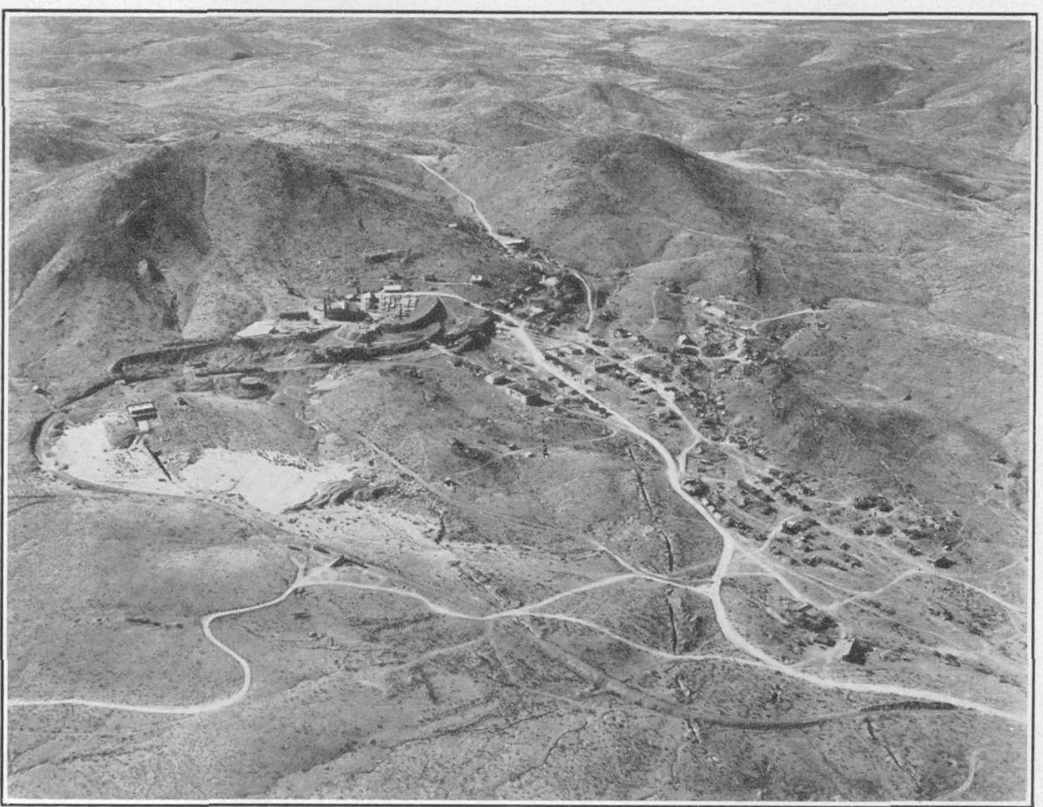

A

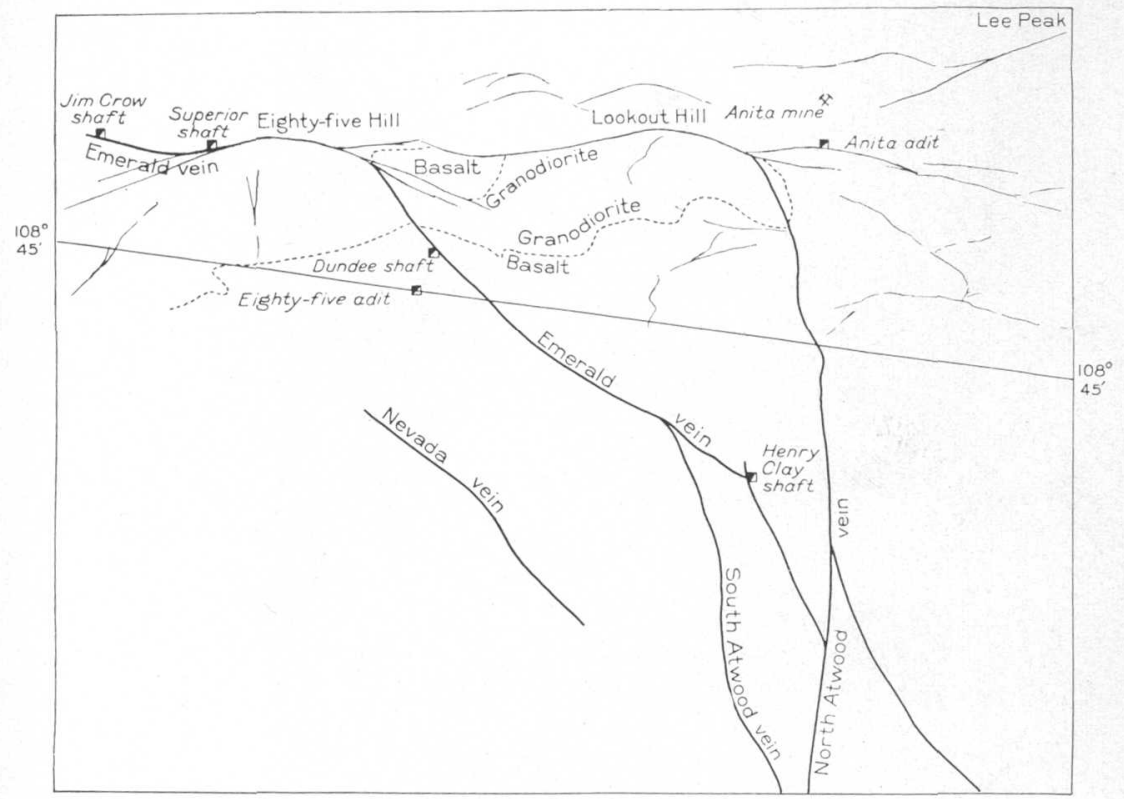

$\mathrm{B}$

$A, B$. AERIAL PHOTOGRAPH, WITH EXPLANATION, OF MAIN PART OF THE LORDSBURG MINING DISTRICT, N. MEX.

Valedon and the offices and shops of the Eighty-five mine in the middle ground. The prominent outcrop of the north Atwood vein is typical of most of the veins of its group. Area included in this view is shown on plate 3. Photograph by Fairchild Aerial Surveys, Inc.

$118359-37-2$ 


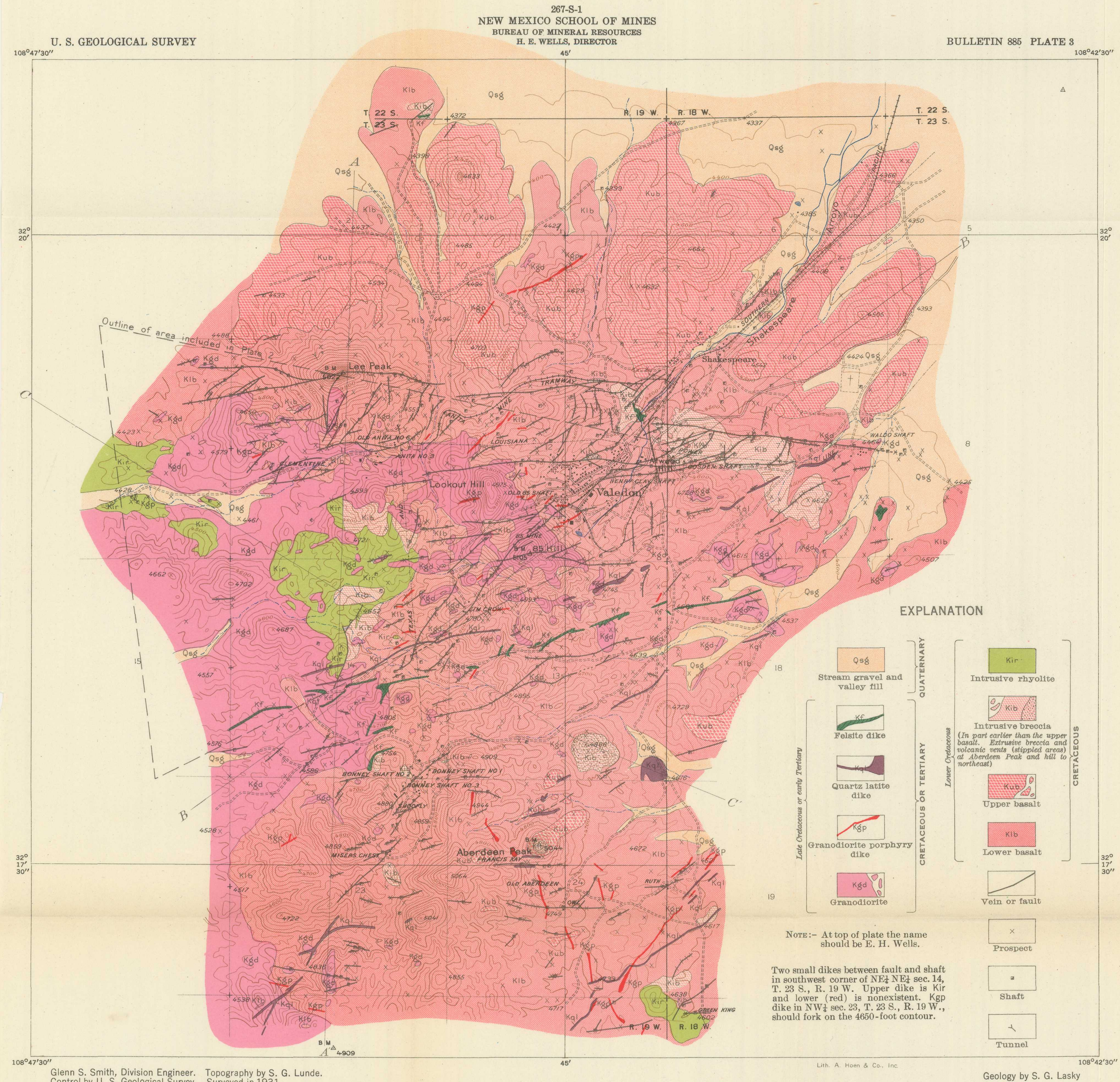

Glenn S. Smith, Division Engineer. Topography by S. G. Lunde.
Control by U.S. Geological Survery. Surveyed in 1931 . Surveyed in cooperation with the New Mexico
Bureau of Mines and Mineral Resources.
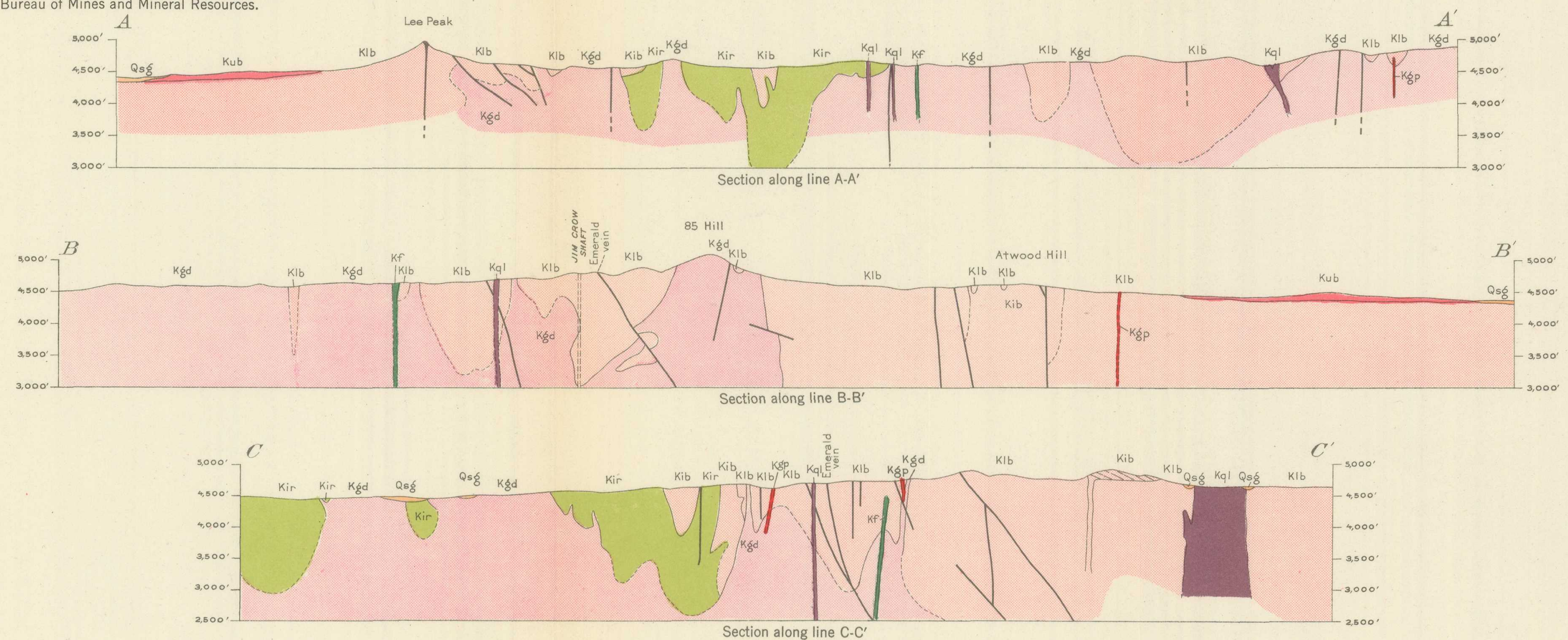

GEOLOGIC MAP AND SECTIONS OF THE LORDSBURG MINING DISTRICT, HIDALGO COUNTY, N. MEX. 
Lower Cretaceous-Continued.

Unconformity.

Upper basalt flows.

Basaltic tuff and breccia, containing thin layers of rhyolite bere and there. May be the extrusive equivalent of the intrusive basalt breccia. Included with the upper basalt flows on the geologic map.

Intrusive basalt breccia, filling volcanic vents.

Unconformity.

Lower basalt flows.

Unconformity.

Pennsylvanian :

Magdalena limestone. Crops out at a few places outside the area covered by this report.

\section{EARLIER (LOWER CRETACEOUS) VOLCANIC ROCKS}

\section{BASALT}

Augite basalt constitutes most of the rock exposed in the Lordsburg district and extends southward under the Tertiaryi lavas and associated fragmental rocks. It has been separated into two map units within the limits of the district, and these are designated on' the geologic map (pl. 3) the lower and upper basalts.

The base of the lower basalt is not exposed, though the workings of the Eighty-five mine penetrate this rock about 2,050 feet vertically. The rock seems remarkably homogeneous throughout this thickness. Nowhere was, any sign of flowage seen, nor does there seem to be any general division into individual flows, though a little breccia is included in the basalt near the Bonney and Misers Chest mines. The rock is soft and easily eroded and is so extensively jointed that it breaks into small angular pieces. It tends to be greenish on surface exposures but is dark gray to black underground. It is characteristically aphanitic, only a few minute laths of feldspar being megascopically visible here and there, and contains a few phenocrysts of colorless augite, generally less than 1 millimeter long, in a groundmass consisting of a felt of labradorite laths (about $\mathrm{An}_{60}$ ) among which are scattered minute grains of augite and subordinate magnetite. The average composition is estimated to be about 50 percent of feldspar, 35 percent of augite, and nearly equal amounts of glass and magnetite. At some places the rock contains many quartz phenocrysts, presumably foreign inclusions, each of which is surrounded by a "fence" of closely packed grains of augite. The topmost part of the formation in the northern part of the district, and much of it south of Leitendorf, is finely porphyritic and purplish and contains several percent of brown hornblende. The augite in this rock is quite fresh, but each hornblende crystal has an alteration border of magnetite, some hornblende being completely altered. 
The upper basalt occupies a band along the north side of the district, and thin remnants of it cap a few of the hills in the vicinity of Aberdeen Peak. To judge from its attitude and distribution, the upper basalt once covered the whole district and has barely been removed from the higher hills. The maximum thickness still remaining is about 300 feet. The formation rests unconformably on the lower basalt, its base being marked generally by a layer of bedded tuff and fine breccia containing a few thin flows of rhyolite. This layer is absent from some of the high points of the irregular surface upon which it lies but reaches an observable thickness of about 15 feet elsewhere. 'The bedding planes in it vary widely in strike and dip and presumably reflect the topography of the underlying erosion surface, the relief of which seems to have been similar to the present relief. A flow of tough shiny black basalt, about 30 feet thick and easily recognized by the rounded" boulders into which it weathers and by a skin of soft rust on the weathered surface, generally overlies the breccia-tuff layer, forming part of the low spurs east of Shakespeare Arroyo. This rock contains a few sporadic phenocrysts of olivine in a groundmass that consists of subordinate magnetite and nearly equal amounts of sodic labradorite and minute prisms of fresh augite in a residuum of glass. The olivine phenocrysts range from 1 to 2 millimeters in length and are variably altered to bowlingite (?) and magnetite. A hard slabby flow-jointed rock overlies the olivine basalt and makes up the rest of the formation. It is brownish gray and fresh-looking and contains a few scattered grains of green augite, as much as 2 millimeters in length, in an aphanitic, trachytic groundmass of glass, tiny grairs of magnetite, and sodic labradorite $\left(\mathrm{An}_{52}\right)$.

Locally the basalt adjacent to the granodiorite stock, for a distance of 15 feet or less, differs considerably from the average rock. It is slightly more crystalline and in general contains minute idiomorphic crystals of biotite in a very fine grained mosaic of orthoclase, oligoclase, and subordinate quartz. The original augite is represented by fibrous uralite. The rock in this zone contains thin indistinct veinlets and irregular patches of orthoclase, quartz, and biotite; and clusters of orthoclase and quartz have been seen in the basalt as much as 90 feet from any visible granodiorite contact. At many places the weathered rock in this border zone is hardly distinguishable from the adjacent granodiorite. These differences in the basalt seem to be the result of metamorphism by solutions from the stock, which tended to convert the basalt into a rock like the granodiorite. ${ }^{6}$

Chlorite is present throughout the basalt but is not prominent. Epidote also is widespread; large parts of the lower basalt are im-

\footnotetext{
${ }^{\circ}$ Lasky, S. G., Igneous assimilation and associated contact metamorphism in the Virginia mining district, N. Mex. : Am. Mineralogist, vol. 20, pp. 552-561, 1935.
} 
pregnated with it, and here and there this rock contains druses of coarsely crystalline epidote and masses of epidosite. The fragmental layer between the upper and lower basalts and the adjacent parts of the lower basalt are more than half converted to epidosite at many places.

\section{INTRUSIVE VOLCANIC BRECCIAS}

Plugs of volcanic breccia intrude the lower basalt at several places in the district. The largest of them forms Atwood Hill and the small hill to the southeast, and just across the railroad to the west is a smaller mass that probably has a subsurface connection with the plug at Atwood Hill. The total length is over a mile, and the average width is about 1,000 feet. A mile and a half to the southwest, in

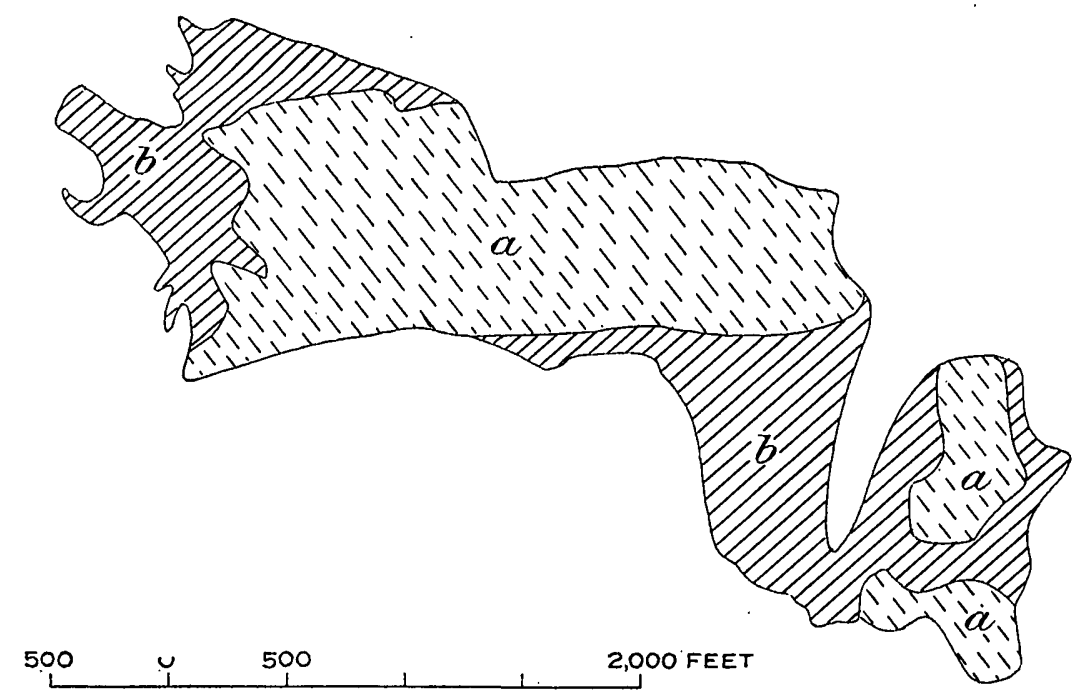

Ficure 2.-Sketch map of the intrusive breccia at Atwood Hill, showing relation between rhyolite (white) and basalt (black) breccias. $a$, Rhyolite; $b$, basalt.

secs. 11 and 14, are several other croppings that may be parts of: another large plug that was disrupted by later intrusions, and smaller masses crop out at several other places. Dikes of the breccia penetrate the surrounding basalt, and the Atwood Hill plug contains included masses of basalt as much as 200 feet in diameter.

The larger plugs are made up of two distinct varieties of breccia-black to green basalt breccia and later white rhyolite breccia. (See fig. 2.) The smaller plugs generally consist of only one or the other. The black breccia contains fragments of the lower member of the basalt cemented by other basalt, together with fragments of both these rocks, in a matrix that ranges from porphyritic basalt to fine-grained breccia. The white breccia contains not only individual fragments of the two rocks of the black breccia and of the black breccia itself but also fragments of a distorted felsite and 
of a fine-grained breccia that in places forms a massive part of the intrusives. The fragments of breccia range from minute particles to pieces 3 inches in diameter, but there seems to be no regularity in the distribution of the different sizes.

The intrusive breccias nowhere cut the upper basalt, but bedded material, identical with parts of the white intrusive breccia and presumably derived from one of the breccia-filled plugs, caps slabby upper basalt on Aberdeen Peak. Thin flows of rhyolite are interbedded with the breccia, and identical rocks cap the hill to the northeast on the Red Copper and Green Copper claims (pl. 4, B); at that place, however, the upper basalt is missing, indicating earlier erosion of that rock. Perhaps the older black breccia of the plugs is the parent material from which was derived the fragmental layer between the lower and upper basalts; if so, the black breccia is older than the upper basalt or equivalent to it, whereas the white breccia is younger.

\section{INTRUSIVE RHYOLITE}

The intrusive rhyolite is a white porcelaneous rock, thoroughly silicified and sericitized, that represents the latest episode of the earlier volcanic period. Its original composition is unknown. The largest outcropping mass in the Lordsburg area is in secs. 11 and 14, south of the Anita mine, where the rock intrudes both basalt and intrusive breccias. To the northwest, in sec. 10, are other croppings that originally may have been part of this same rhyolite mass. At the Green King mine, in the southeast corner of the district, lies a smaller mass that also displaces some of the intrusive breccia. Flow jointing can be seen here and there in these rhyolite masses, and the rock is intricately and minutely flow-distorted in the dikelike parts. All but one of the hills that rise out of the valley fill near Gary siding and south of the highway consist chiefly of autobrecciated rhyolite, and two small bodies of rhyolite crop out in the basalt hill north of the highway. (See pls. 1 and $4, A$.)

'The present outcropping bodies of the rhyolite are believed to be remnants of volcanic necks, and the general association of the rhyolite with intrusive breccia, as shown on the geologic maps, suggests that the lava sought an outlet chiefly through the same vents that were open during the preceding active period.

\section{LATE CRETACEOUS OR EARLY TERTIARY INTRUSIVES}

\section{PORPHYRITIC GRANODIORITE}

An irregular stock of porphyritic granodiorite intrudes all the rocks thus far described and is the principal host for the known ore cieposits. The rock is fairly uniform throughout the main part of the mass but is darker and variably finer-grained in a thin local 
border zone and in the narrower apophyses. It is decidedly pink and strongly porphyritic, though in the hand specimen the texture seems nearly granitoid. The phenocrysts range from 1 to more than 5 millimeters in length and include oligoclase-andesine $\left(\mathrm{An}_{30}\right)$, which constitutes about 40 percent of the rock, a little quartz and pink orthoclase, and about 3 percent of green hornblende and brown biotite, both' generally chloritized, distributed in a granitic intergrowth composed of pink orthoclase and slightly less quartz. Titanic, apatite, zircon, and magnetite, in part derived from hornblende and biotite, are the accessory minerals.

The dark fine-grained border zone ranges from a fraction of an inch to 20 or 25 feet in thickness and has been noted only where the stock intrudes basalt. The rock in this zone contains much augite and much more magnetite than is common to the main mass, and the plagioclase is more calcic than the plagioclase in the rest of the rock. 'These differences have been interpreted as the results of partial assimilation of the adjacent basalt. ${ }^{7}$

Small quantities of epidote are scattered throughout the granodiorite, but this mineral is much less abundant than in the basalt, a condition that presumably reflects the relative quantities of ironbearing minerals in the two rocks.

\section{GRANODIORITE PORPHYRY AND APLITE DIKES}

As shown on the geologic map (pl. 3), the granodiorite stock has many dikelike apophyses, but in addition to these, granodiorite porphyry dikes cut the stock and the surrounding rocks. The porphyry dikes are mineralogically similar to the granodiorite of the stock, though they are finer-grained and have a greater range in size between phenocrysts and groundmass. Some of them have been mapped, but the time and care necessary to trace them out, particularly in the granodiorite, where contrast between dike and stock is not great, made it impracticable to map them all.

Vague aplitic bands and a few distinct aplite dikes are present here and there, but they are generally small, and none were mapped. Some have glassy borders.

\section{QUARTZ LATITE DIKES}

Quartz latite dikes are prominent in parts of the Lordsburg district, and a small plug of this rock crops out near the southeast border. The dikes are generally long and narrow; one that averages less than 40 feet in thickness extends without a break for nearly a mile. Many of them line up to form strings of considerable length: and it is possible that the dikes of a particular string have a subsur-

${ }^{7}$ Lasky, S. G., Igneous assimilation and associated contact metamorphism in the Virginia mining district, N. Mex. : Am. Mineralogist, vol. 20, pp. 552-561, 1935. 
face connection and are segments of an extremely long and thin master dike. One such string, composed of seven major segments, extends a distance of 3 miles across the full width of the district. A few of the dikes are pronged, but generally they are simple tabular masses that are strongly sheeted at the borders. Many have been bleached white by hydrothermal solutions and given a tan color by later oxidation. Others, less altered, are characteristically light gray and are spotted with white phenocrysts of orthoclase and sodic plagioclase, ranging from less than 1 to about 4 millimeters in length, and minute pseudohexagonal spangles of brownish-green biotite in a gray microcrystalline groundmass of quartz, orthoclase, and plagioclase. Quartz phenocrysts are common in places, and most specimens contain rare phenocrysts of apatite and titanite.

The quartz latite dikes cut indiscriminately through all the rocks thus far described but are older than the Miocene(?) volcanic rocks, the basal breccia of which lies upon the eroded outcrop of one of them. They are younger than the period of ore deposition but were themselves later mineralized. One of them cuts directly across the Emerald vein on the Jim Crow claim and across the next vein west, both of which contain the vein filling typical of the district. The dike itself, however, is strongly sericitized and carbonated throughout its course and is impregnated with pyrite. Farther east one of the same string of dikes lies along a preexisting vein, but the dike in turn is cut by veinlets of quartz, calcite, and fluorite and is strongly sericitized and pyritized.

\section{FELSITE DIKES}

The term "felsite" is given to white silicified dikes, generally having autobreccia borders, that are identical in appearance with the rock of the intrusive rhyolite, though not of the same age. Nowhere do they cut the rhyolite, but they are later than the granodiorite and therefore must be later than the rhyolite. They are also later than the veins, but their age relation to the quartz latite dikes and to the Miocene (?) rocks is not known, though they are believed to be earlier than the Miocene (?) rocks.

\section{LATER (MIOCENE?) VOLCANIC ROCKS}

Miocene(?) lavas and associated breccia and tuff make up the main part of the Pyramid Mountains and evidently once covered the entire area, though they have been almost completely eroded from the Lordsburg district. They include a variety of rocks, but no attempt was made to study them in detail.

The main mass of Miocene(?) rocks borders the Lordsburg district at the south and east edges of Leitendorf camp, where the base of the formation consists of rhyolitic volcanic breccia resting on an 
eroded surface of the Cretaceous basalt. The Leitendorf Hills, which rise 500 feet above the adjacent country, are composed almost entirely of this breccia, and the low hills rising out of the alluvium to the northeast along the Animas road consist of the same material. (See pl. 1.) The breccia is generally massive but contains some wellbedded layers. It is light brown to white, the color depending upon the proportion of volcanic ash to rock fragments. Locally the basal part contains fragments of the older rocks and of the veins. The formation is clearly of subaerial accumulation, and the general paucity of ash suggests that it came from a nearby source.

The breccia is cut by several dikes, some of which are apophyses of the volcanic neck that forms North Pyramid Peak, and lava from that vent caps the small group of hills to the north, resting unconformably on the breccia. The rock of the neck, dikes, and flows is light chocolate brown and is erratically speckled with phenocrysts of white feldspar (sodic andesine) 3 millimeters or less in length and slightly smaller spangles of shiny black biotite. The groundmass is aphanitic and consists chiefly of plagioclase microlites in a micropoikilitic intergrowth with quartz and subordinate orthoclase; it contains also a little glass and is sprinkled with considerable magnetite and hematite dust, to which the color of the rock is due. Dikes and flows of similar rock lie to the south, beyond the mapped area.

- At the northwest end of the Leitendorf Hills the breccia contains sills and dikes of flow-streaked obsidian, and obsidian float has been seen elsewhere in the mapped area. South of Rock House Canyon the breccia, which at that place is very ashy, is overlain by a roughsurfaced quartz latite porphyry containing 30 to 40 percent of fineto medium-grained phenocrysts in a partly spherulitic groundmass of purplish-brown glass. The phenocrysts consist of white plagioclase, glittering sanidine, quartz, thin books and flakes of biotite, and grains and clusters of magnetite.

Interlayered flows of andesite and beds of tuff cap one of the hills north of Pyra siding, west of Lordsburg. The andesite is a sparkling gray to light-brown seriated porphyry and contains abundant small phenocrysts of andesine, augite, and hornblende in a groundmass that is predominantly glassy.

\section{STRUCTURE}

\section{ATTITUDE OF THE ROCKS}

The Cretaceous basalt flows and associated fragmental rocks contain no reliable features that indicate their general attitude. Dips and strikes can be observed in the breccia-tuff patches and layers, but they are erratic and seem to reflect only local details of the underlying 
surface. The best information is given by the attitude of the erosion surface upon which the formation mapped as upper basalt lies, but even this information is of debatable value. Where still preserved in the district, that surface now has a general slope to the north and northeast of 400 to 500 feet to the mile, and the attitude of the overlying flows reflects this slope. The flows below the unconformity may have a similar attitude, because it is unlikely that there was any marked local deformation of the rocks in the interval between expulsion of the lower and upper basalts, but of this there can be no assurance.

The plugs of intrusive breccias and of intrusive rhyolite fill volcanic vents through which at least part of the exposed rocks were derived. One of these vents forms Atwood Hill and has a cross section of about 0.2 square mile. It is several times as long as wide but is hardly elongate enough to indicate a fissure eruption; rather it seems to represent three subcircular vents in line and having direct connections with one another. The workings at the Atwood (Alamo) mine explore the south edge of this vent to a depth of 750 feet and show it to dip inward at about $75^{\circ}$. (See pl. 22.) The detached croppings of white rhyolite and intrusive breccias in secs. 10,11, and 14 may originally have been parts of a second large vent, which was torn apart by intrusion of the granodiorite, and if so this vent had a cross section of nearly a square mile. The bodies of bedded breccia on Aberdeen Peak and on the hill to the northeast may be parts of a cone that once surrounded this vent or cluster of vents. The breccia dips at an average of about $30^{\circ}$, whereas the surface upon which it rests dips only $5^{\circ}$, and the projected continuation of the beds up the dip carries them toward the vent, which is only a mile away.

The granodiorite stock forms a horseshoe-shaped band that borders the west side of the district, opening eastward. The continuous exposed length of the band is $61 / 2$ miles, and the average width is about $1 \frac{1}{2}$ miles, giving an exposed area of about 10 square miles. Outliers, generally close to the main mass, are common and are particularly abundant on the inner side and ahead of the thin northern horn of the horseshoe. They doubtless connect with the main mass below the surface and suggest that the stock may be appreciably larger at no great depth. The outline of the stock is fairly regular in the southern part, but roof pendants or inclusions of country rock, great embayments, and irregular apophyses into the surrounding rock, encompassing masses of it at places, are common in the northern half. The inclusions and pendants range from masses or residual roots less than 50 feet across to blocks that have an average diameter of 1,000 feet or more, and many of the large embayments in the stock may be the upper parts of masses pendent into it at greater depths. The 


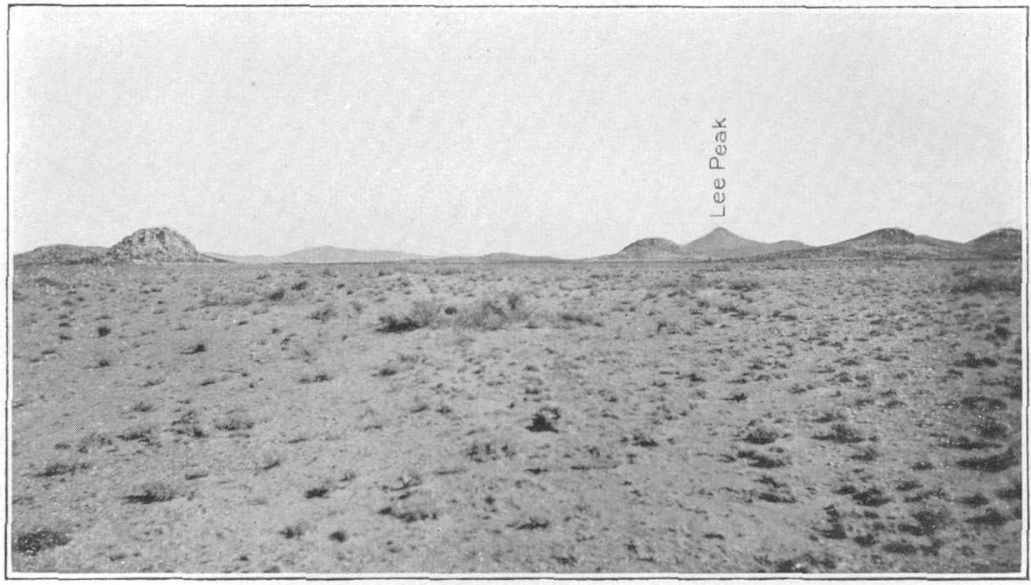

A. VOLCANIC NECKS EXTENDING ABOVE THE ALLUVIUM SOUTH AND EAST OF GARY SIDING.

These hills consist chiefly of an auto-breccia of the intrusive rhyolite. Burro Mountains in the distance. View looking eastward.

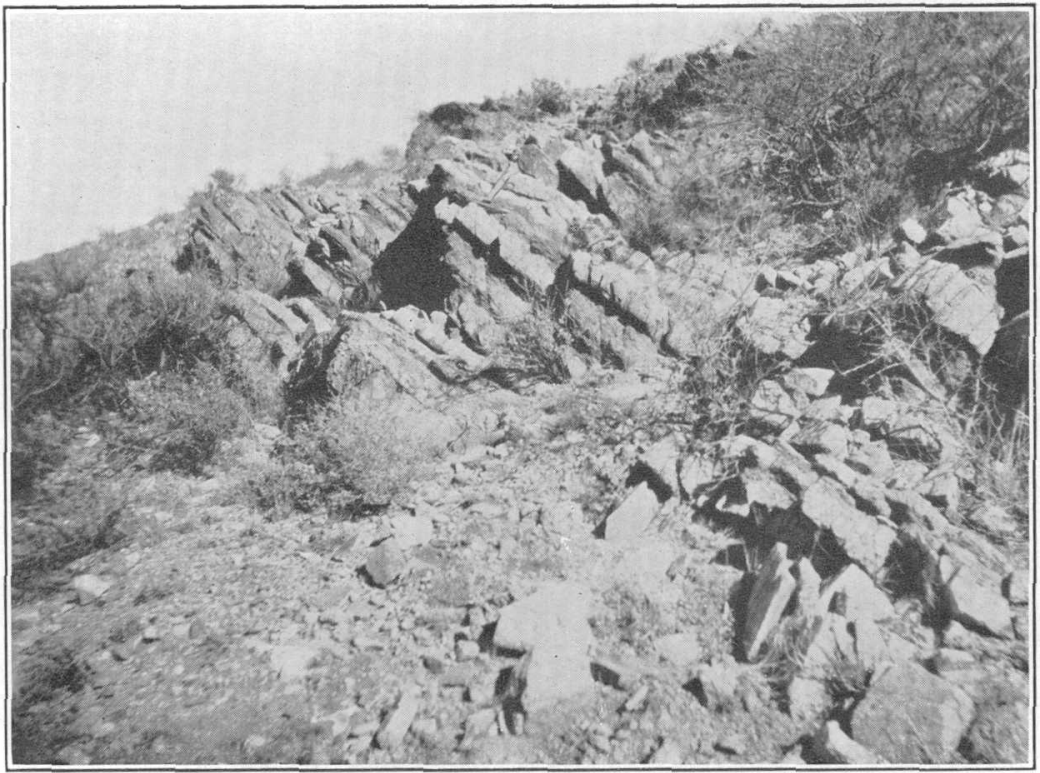

B. STEEPLY DIPPING BEDDED RHYOLITE BRECCIA CAPPING HILL NORTHEAST OF ABERDEEN PEAK.

This rock is the extrusive equivalent of some of the intrusive breccia of Atwood Hill and other vents. 


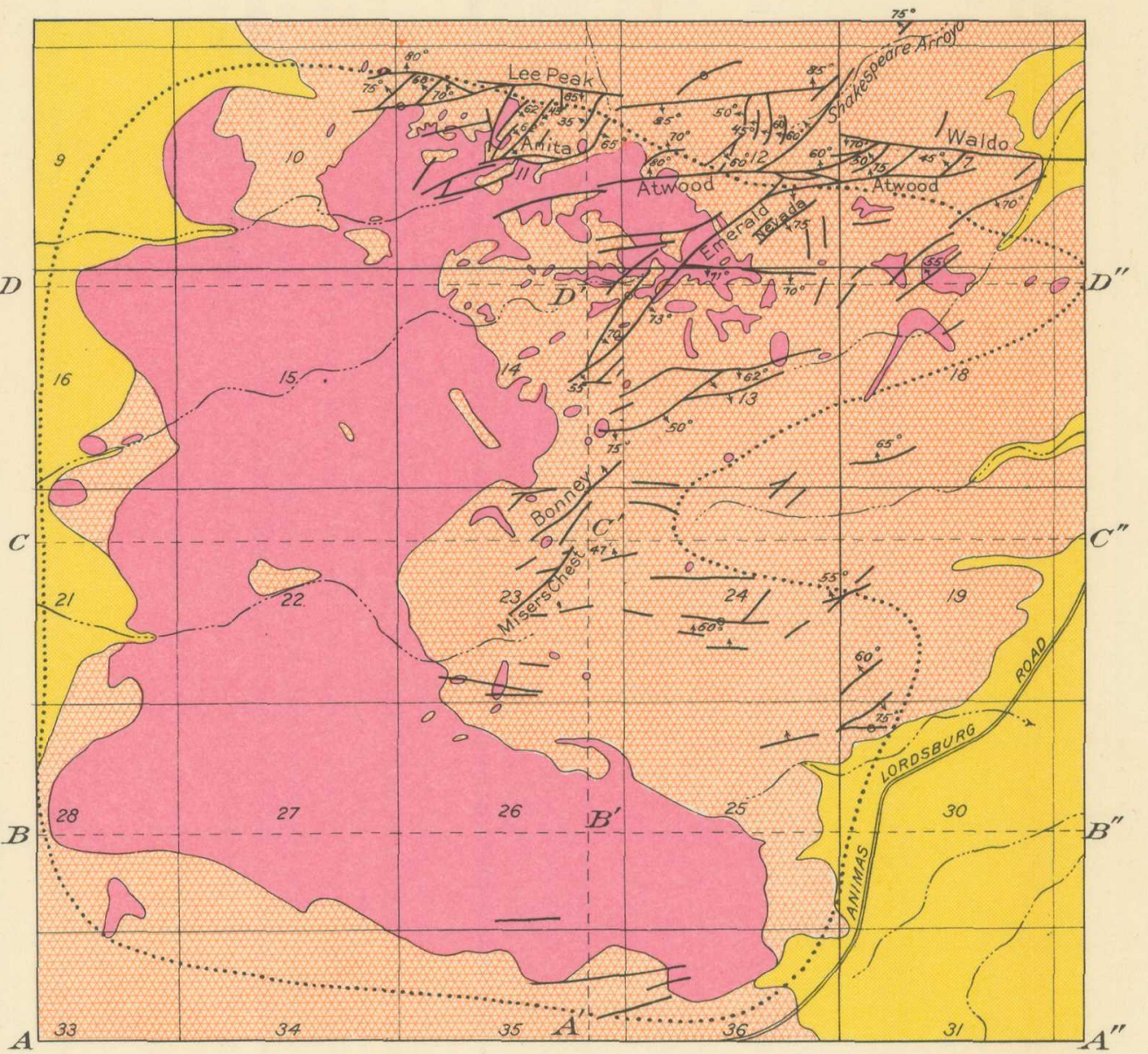

EXPLANATION

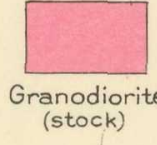

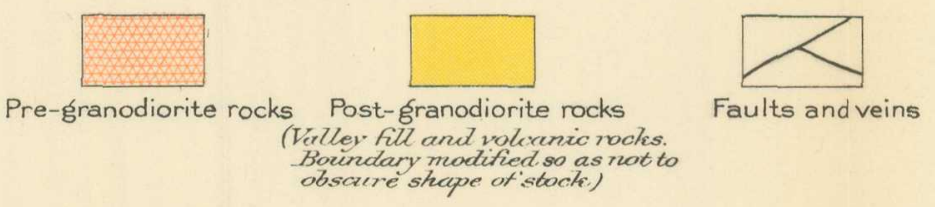

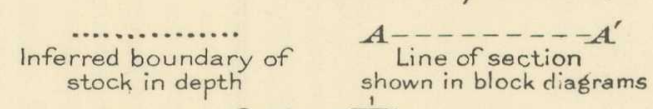

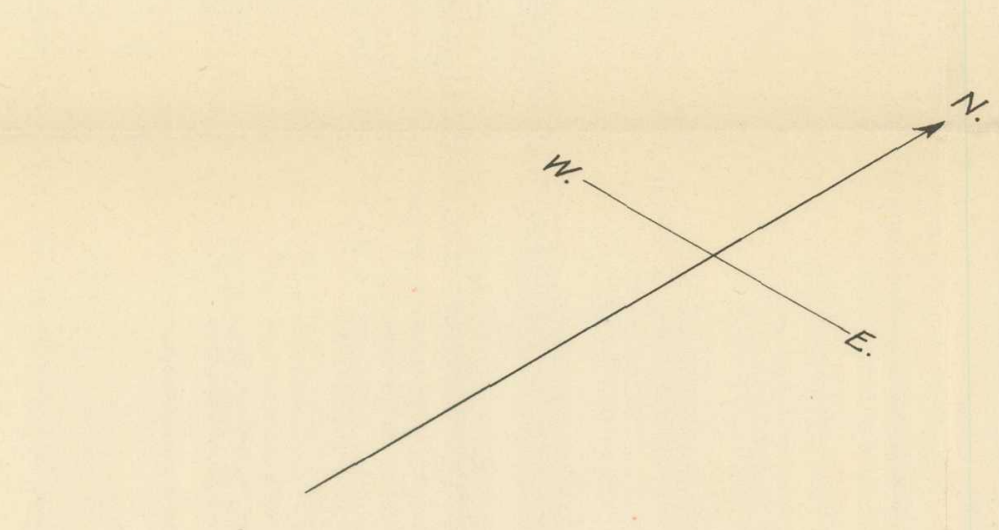

1
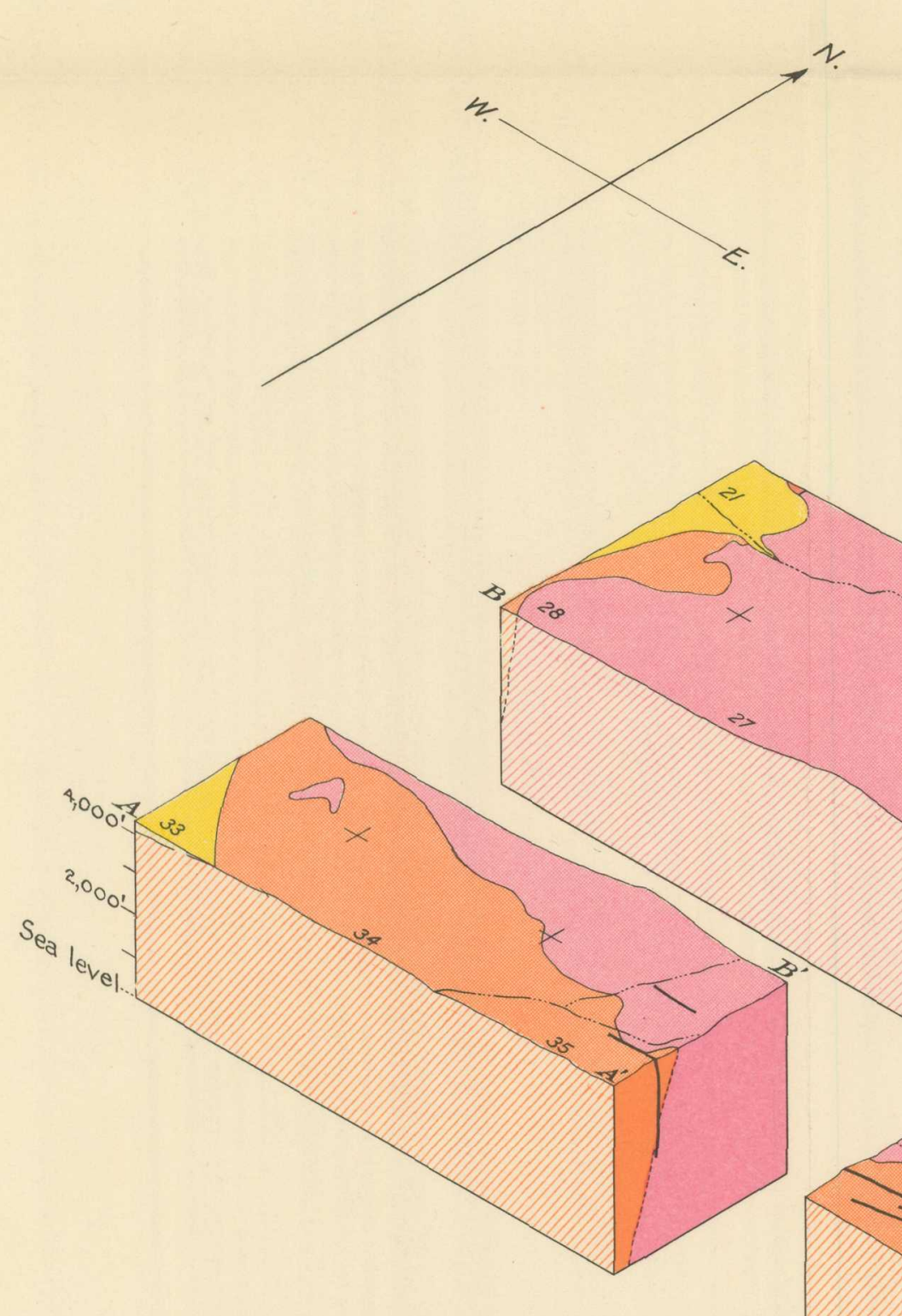

Scale 62,50 2 MLES 
position of other pendants or inclusions that have been removed by erosion can be inferred from the presence of typical border-zone granodiorite within the main part of the stock. The thickness of this border-zone rock as noted underground and in arroyos cutting across surface exposures averages less than 20 feet normal to the contact, yet some outcropping areas of this rock cover thousands of square feet. Nearly all these areas are adjacent to visible contacts. Presumably they are flat-lying contact zones from which the overlying basalt has been barely eroded, and the topographic surface at those places is therefore essentially the original surface of the granodiorite. These areas are so extensive in the northern part of the granodiorite area that the present topography there may be taken as giving a general picture of the original upper surface of that part of the stock. Indeed, the whole northern horn of the stock must be near the topmost part.

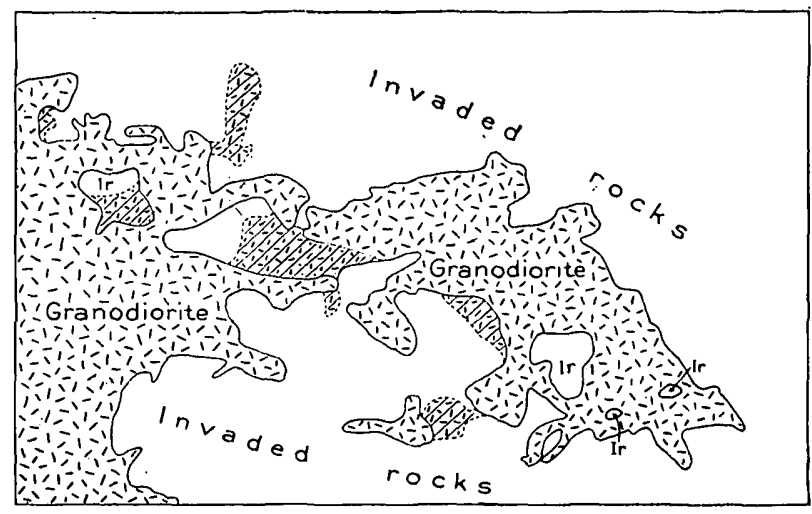

O $1 / 2$

Figure 3.- Map of the northern horn of the granodiorite stock, showing the probable outline if only about 20 feet of eroded material were restored. Dotted lines show present outline. Ir, Invaded rocks.

Figure 3, which should be compared with the geologic map (pl. 3), shows what the shape of the outcrop of the northern horn would be like if only about 20 feet of eroded material were restored-that is, just enough to cover the border-zone rock with basalt. Eighty-five Hill is geologically, as well as topographically, the highest part of the horn, and a consideration of the known contacts, as shown in plate 13, suggests that not much more than 500 feet has been eroded from that part, though dikes and chimneys doubtless extended much higher. The central and southern parts of the stock have been eroded to a much deeper core; the number of outliers gradually lessens southward, and the number of pendants or inclusions, observable or inferred, also lessens until they are apparently absent in the southern part, and the contacts in that part are much more regular. 
Plate 5 shows the possible general shape and size of the stock in depth, as inferred from the distribution of outliers and from an appareni spatial relation of faults to the observed outline. The main group of faults follows the northern horn of the stock, another group follows a set of outliers distributed south and ahead of this horn, and a third, minor group lies along the outer edge of the southern horn. The outliers followed by the second group presumably join the main mass below the surface and may well be the upper points of an intrusive ridge that forms the inner edge of the northern horn, as shown in plate 5. A fourth group of faults lies parallel to the inner side of the southern horn, though some distance away, and if the other three groups are definitely oriented along the borders of the stock, as suggested, then this fourth group may be inferred to mark the position in depth of the inner side of this horn. The final picture that one obtains of the stock is therefore a mass, roughly square and about 4 miles on a side, having a deep embayment on the east and surmounted by a ridge that follows the other three sides and gradually rises to the south. The shape is that which would be obtained if one were to clasp the right fist with the left hand, keeping the left forefinger and thumb above the level of the fist.

\section{FAULTS}

The faults of the Lordsburg district are largely confined to three zones, the strongest of which extends eastward through the Anita, Henry Clay, and Atwood mines. (See pl. 3.) A second zone, in which lie the Eighty-five, Bonney, and Misers Chest mines, extends southwestward from the east end of the first zone, and a third, more diffuse zone, containing only a few nonpersistent members, lies south of Aberdeen Peak. These faults fall roughly into two sets, one trending eastward and the other northeastward, although, as shown by figure 4, there is no real break between the two sets. Members of each set join members of the other and change in strike along their course from one set to another, and members of each set have short spurs of the other extending from them. A few faults trend northward. These include late faults that slightly offset some of the main ones and also the short breaks that link together the eastwardtrending faults of the Anita-Atwood zone. The two main sets have dips on both sides of the strike at angles between $45^{\circ}$ and $90^{\circ}$, though they are predominantly steep. The strike and dip of many of the faults vary within wide limits, and moderate changes of strike and dip are common. These changes bear no apparent relation to fault junctions nor to changes in rock formations.

Nearly all faults originated prior to the period of ore formation, and they furnished the channels for the ore-bearing solutions. Many 
of them have bold, wall-like siliceous outcrops, but many others, having less quartz or less strongly silicified walls, could be traced only with difficulty were it not for the many prospect pits along them. Most of those having prominent outcrops belong to the eastwardtrending Anita-Atwood set, and this led to the local belief that the eastward-and northeastward-trending faults are of different ages. The fault pattern indicates, however, that these sets originated at the

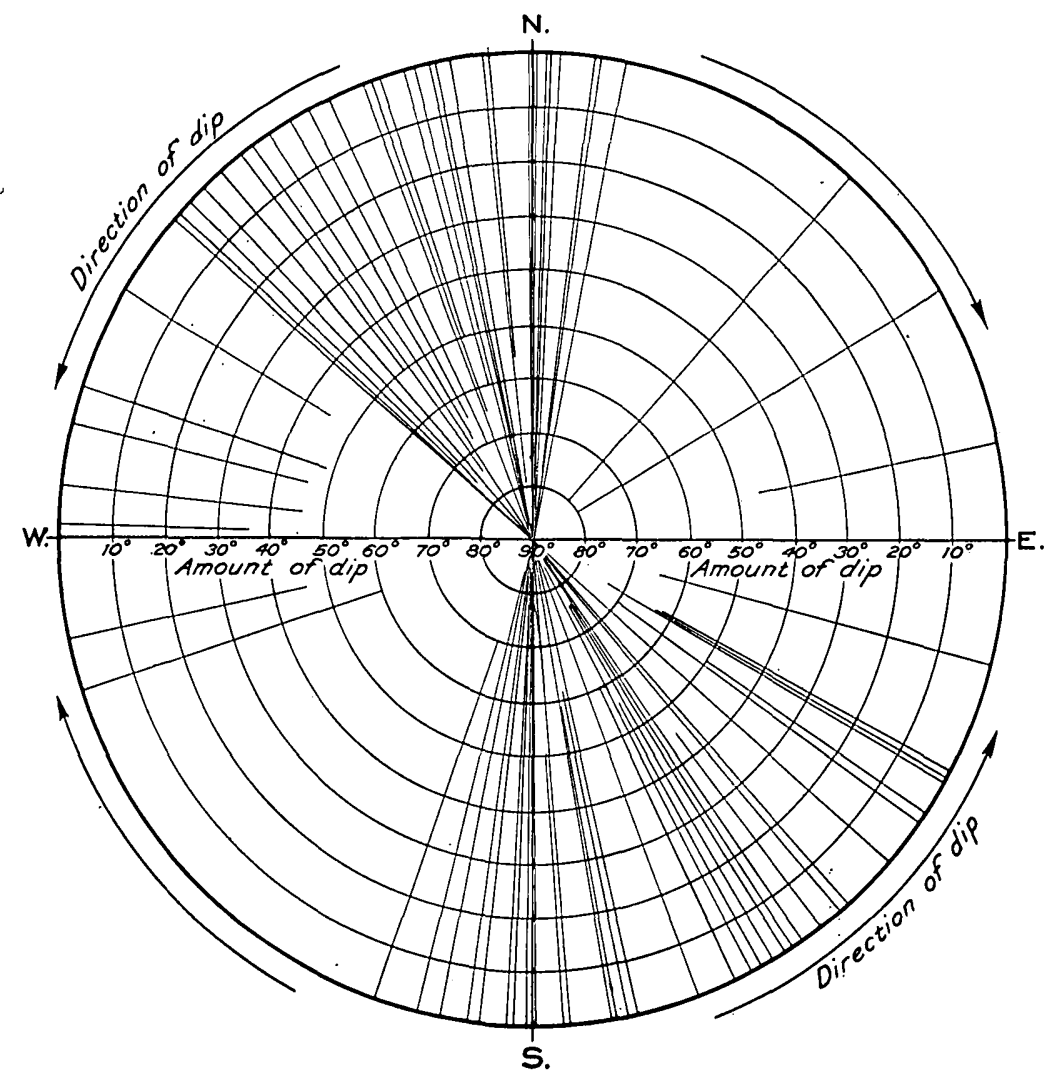

FIgune 4.-Direction and amount of dip of the faults of the Lordsburg mining district. Lines extending through the circle indicate vertical dips. The chart shows directly the amount and direction of dip and therefore indirectly the relation between dip and strike.

same time, and consequently the general prominence of the outcrops of one set implies nothing more than that the faults of that set were more permeable at a time when the mineralizing solutions were highly siliceous. (See pp. 30-41.) A few faults, however, originated later than the others, for they distinctly break veins that contain most of the mineral suite, whereas they themselves are either barren or carry only minor amounts of the latest minerals. Here and there one of them offsets a prominent vein outcrop a few feet or marks it with slickensides, but generally they have no surface expression. 
Movement along the faults recurred spasmodically several times while the vein filling was being deposited, four episodes being shown by the brecciated and recemented minerals. Post-ore movement occurred along all faults, and the quartz latite and felsite dikes indicate an additional episode of fracturing subsequent to the ore-forming period, giving at least six stages of reopening. As described in the section on ore deposits, the mineral deposition that accompanied each reopening of the veins was different from that of each preceding stage; consequently the position of the openings formed during each stage of movement can be inferred from the distribution of the different varieties of vein matter, because the vein filling indicates the openings that existed at the time of deposition. Plate 13 . shows this distribution in as much detail as possible for the Emerald vein. The general impression is that the openings produced during one stage of faulting were in large part independent of those produced during any preceding stage, although at places there is a rough conformity. Most outstanding is the nearly identical position of the trunk openings of each stage, as shown by the coincidence of the roots of the mineralization shoots of the different stages. The two deeply penetrating prongs of supergene alteration, which presumably lie along channelways of very easy circulation opened by post-ore movement, coincide closely with the position of earlier openings, and on the lower levels of the mine the planes of the post-ore faults seem to coincide almost exactly with those of the two preceding stages of movement.

Movement occurred along all fissures, as proved by the presence of gouge and breccia and of fault striae, but only at the Eighty-five mine has it been possible to determine the direction and amount of movement with any degree of satisfaction. At that mine the net cumulative displacement of all recurrent movements along the Emerald fault hardly exceeds 150 feet and is nearly horizontal, the hanging wall having moved southwestward, as indicated by the position of the granodiorite and basalt contacts in the two walls of the fault. (See pl. 13.) The walls are marked by nearly horizontal grooves as much as $1 \frac{1}{2}$ feet deep and 4 feet across. The flat-lying boundaries of the mineralized shoots along this fault, as shown in plate 13 (oversheet), imply that the most permeable channelways along it were flat to a considerable degree, and this attitude may be a reflection of the horizontal movements. Deep, nearly horizontal grooves also mark the walls of the Bonney vein, in the same vein zone, but nothing there indicates the amount of displacement.

The general pattern of the eastward-trending Anita-Atwood fault zone suggests that the main members of that zone also may have had essentially horizontal movement. The zone consists of two lines of 
steeply dipping eastward-trending faults connected by more flatlying cross members. (See pls. 3 and 5.) The cross faults tend to bend eastward into the northern line of the eastward-trending faults and westward into the southern line and include two sets, one dipping $35^{\circ}-75^{\circ} \mathrm{W}$. and the other $45^{\circ}-65^{\circ} \mathrm{E}$. The pattern is such as might be produced by shearing along the two lines of eastward-trending faults, accompanied by distortion of the slab of rock between them. ${ }^{8}$ 'The cross faults may be either sympathetic shear planes, the norti side of the fault zone having tended to move eastward and the south side westward; or: they may be tension faults with one group of shear planes undeveloped, the direction of movement being just the reverse. Figure 5 illustrates these alternatives. The fact that the cross faults include two sets dipping toward each other may indicate that they are sympathetic shear planes, and the direction of movement implied by this possibility is supported by the draglike bend of the cross faults into the eastward-trending shear planes.

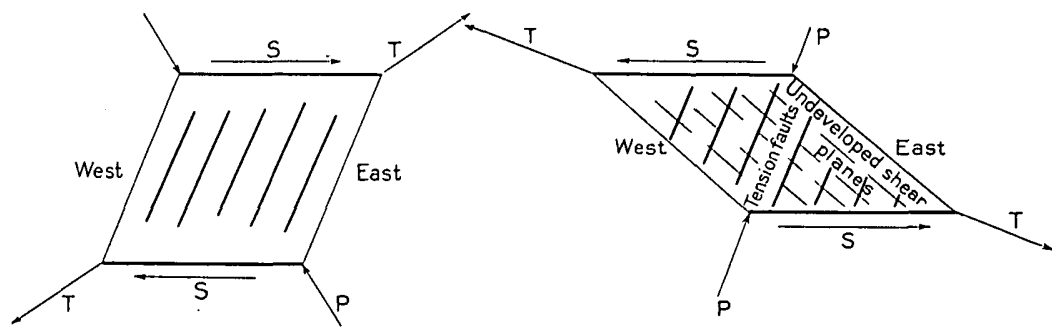

$\mathbf{A}$

B

Ficure 5.-Similar fault patterns formed by shearing couples acting in the same planes but in opposite directions. $A$, Two sets of shear planes produced by shear along the eastward-trending set. Arrows $(S)$ show the direction of shear and of the resulting movement. $\mathbf{P}$ and ' $\mathrm{I}$, Compressive and tensional components. $\mathbf{B}$, Eastward-trending shear planes accompanied by tension faults, the second set of shear planes being undeveloped. The pattern is the same as that shown in A, but the direction of shear is opposite.

The spatial relation of the fuults to the outline of the stock, as described in a preceding paragraph, may mean that the faults are a direct result of the intrusion, but it would be difficult to explain horizontal movement along the faults if that were true. Furthermore, it should be noted not only that the principal fault zone follows the northern horn of the stock, but also that the same zone contains the principal volcanic vents of the district. These include (1) the Atwood Hill vent, which is definitely elongated parallel to the trend of the zone, (2) the vent.or cluster of vents in secs. 10,11, and 14, and (3) the center of eruption indicated by the croppings of intrusive breccias and rhyolite farther west in secs. 8 and 9 . It seems probable,

${ }^{8}$ Leith, C. K., Structural geology, pp. 24-28, 44-47, 1923. 
therefore, that both stock and faults are localized in a long-established zone of weakness, and that the stock affected the location of the faults only in having been a bulwark against the stresses, probably regional, that actually caused them.

\section{INTERPRETATION OF GEOLOGIC HISTORY}

The decipherable geologic history of the Lordsburg mining district began with the comparatively quiet effusion of a large quantity of basalt during the Cretaceous period, probably in early Comanche time. A quiescent period followed, and some of the lava was eroded, after which lavas again broke through to the surface, though this time during recurrent stages of activity, in part quiet, in part explosive, instead of during a single long-continued quiet stage. The new lavas included basaltic and rhyolitic rocks, and some of the vents through which they were derived lie within the district.

If these volcanic rocks are early Comanche, as they seem to be, their extrusion presumably was followed by deposition of later Comanche and Upper Cretaceous sediments. The geologic record of this event is missing, however, and the next recorded episode was the intrusion of an irregular stock of porphyritic granodiorite, probably in late Cretaceous or early Tertiary time. Intrusion of the granodiorite was accompanied on a small scale by partial assimilation of the intruded basalt and by metamorphism of the basalt at the contact. Faulting began shortly thereafter, and the fault fissures became the sites for the ore deposits of the area. It is presumed that water and other volatile materials containing dissolved constituents were driven off during cooling and solidification of the granodiorite and of the larger body of magma from which this rock came and that these solutions were forced into the fault fissures, the dissolved matter, which included the ore-forming constituents, being there deposited. Fissuring of the rocks continued during and after this period of mineral deposition, and a few of the new fissures reached down to still fluid parts of the magma, some of which entered the fissures to form the quartz latite and perhaps also the felsite dikes. Additional expulsion of volatile matter from the magma caused a slight mineralization of the quartz latite.

The stock and associated ore deposits were later uncovered by deep erosion, after which, in Miocene (?) time, volcanic activity was resumed, starting with explosive violence and covering the eroded rocks and vein outcrops with a mantle of volcanic ash and breccia. This in turn was covered by new floods of lava. Subsequent erosion, still going on, has removed the Miocene (?) rocks from the Lords. burg district and has reexposed the earlier formations. 


\section{ORE DEPOSITS}

The copper deposits of the Lordsburg mining district constitute one of the few known examples in the United States of the coppertourmaline type of ore deposits, a type characterized by the association of tourmaline and chalcopyrite and by a paucity of other valuable sulphides. ${ }^{9}$ The Eighty-five mine, on the Emerald vein, contained the most productive deposit of this type in the country, about 1,500,000 tons of ore having been mined. from it to the end of 1931, when the mine was closed.

\section{HISTORY OF MINING AND PRODUCTION}

The first claim location in the Lordsburg district was made on April 7, 1870. The general vicinity had been visited in 1854 by Lt. J. G. Parke in the course of Federal explorations and surveys for a railroad route, ${ }^{10}$ but the mineral possibilities of the district evidently were not known to his party. Parke's route extended through Steins Pass, near the Arizona line, thence northeastward across the Animas Valley and around the north end of the Pyramid Mountains and southeastward around the southern base of the Burro Mountains and Cooks Range. That is the general route now followed by the Southern Pacific Railroad in southwestern New Mexico. The croppings seem to have been prospected moderately by 1873 , when the district was visited by G. K. Gilbert, geologic assistant with the Wheeler Survey, for he wrote: ${ }^{11}$

The purest quartz veins, resisting the destructive agents by which the country rock is degraded, project above the surface in long, ragged walls. Other veins, less conspicuous but more attractive to the miner, contain, in the quartz, argentiferous ores of lead and copper and with the building of the Southern Pacific Railway may become of economic importance. For the present, however, all mining operations are suspended by the proprietors of the veins, because too expensive for profit in so sterile and remote a place.

One of the earliest arrivals in the district was a man named Ralston. The camp that grew up was named after him and is shown on the maps of the Wheeler Survey as one of the frontier telegraph stations of the Signal Corps. It is the present village of Shakespeare. Shortly after Gilbert's visit the vicinity of Lee Peak is said to have been salted with diamonds, ${ }^{12}$ and in the stampede to the

\footnotetext{
${ }^{9}$ Lindgren, Waldemar, Mineral deposits, 4th ed., pp. 684-686, 1933.

${ }^{10}$ Parke, J. G., U. S. Pacific R. R. Expl., vol. 7, pp. 152-154, 1856.

גI Gilbert, G. K., The geology of portions of Arizona and New Mexico: U. S. Geog. and Geol. Surveys W. 100th Mer: Rept., vol. 3, p. 514, 1875.

12 Jones, F. A., New Mexico mines and minerals, p. 5, Santa Fe, 1904. Otero, M. A., Report of the Governor of New Mexico to the Secretary of the Interior for 1903, p. 72.
} 
district that followed the "discovery" of dianonds there, the population of Ralston grew to more than 3,000 persons. As anticipated by Gilbert, activity increased upon arrival of the Southern Pacific Railroad, which reached the site of Lordsburg late in 1880, and a small smelter was erected at Shakespeare to treat the ores that were expected to be mined. It was completed in February 1882 and made four runs between then and December, when it was shut down for lack of ore. The site of the smelter is marked by a small slag dump in Shakespeare Arroyo. Prior to the erection of this smelter, a little ore had been shipped to smelters at Denver and Pueblo, Colo. The Last Chance and Venus (Viola) veins, at Leitendorf (Pyramid) camp, were discovered in that period. Mineral showings were found by the railroad company while boring for an artesian well in the valley near Lordsburg, and considerable excitement resulted, during which several shafts were sunk. ${ }^{13}$ High-grade silver ore is said to have been uncovered, but this ore doubtless consisted of float in the valley fill; such pieces have been found in excavations at Lordsburg in more recent years.

The miners and prospectors of the period were interested only in silver ores, and the entire district became comparatively inactive after the price of silver dropped from above $\$ 1$ an ounce prior to 1890 to 78 cents an ounce in 1893 . Activity was not resumed until a sharp rise in the price of copper to more than 17 cents a pound in 1899 directed attention to the district as a copper-bearing area. Miguel A. Otero, governor of the Territory at that time, described the situation as follows: ${ }^{14}$

The diamond fraud of the early seventies, the financial failure of several prominent capitalists then interested in the camp, the death of others, and failure of processes of the time to save values, inaccessibility of the camp, troublesome Indians, and fall in silver proved burdens greater than the camp could stand, and it was not until 1899 , when the rise in copper put prospectors to hunting up copper mines regardless of ancient history, that Shakespeare again came to the front.

According to Otero, Shakespeare was one of the most active camps in Grant County ${ }^{15}$ at that time. Attempts were made to concentrate the ores of the Misers Chest, Aberdeen, Atwood, and Dacotah Pearl claims, and new smelters were built. The most disastrous attempt seems to have been that of the Lena Mining \& Milling Co., which built a concentrating plant at Lordsburg that ran only a few months.

\footnotetext{
${ }^{13}$ Burchard, II. C., Report of the Director of the Mint for 1881, p. 333, 1882.

14 Otero, M. A., Report of the Governor of New Mexico to the Secretary of the Interior for 1903 , p. 72 .

${ }^{15}$ Hidalgo County was part of Grant County until July 1920.
} 


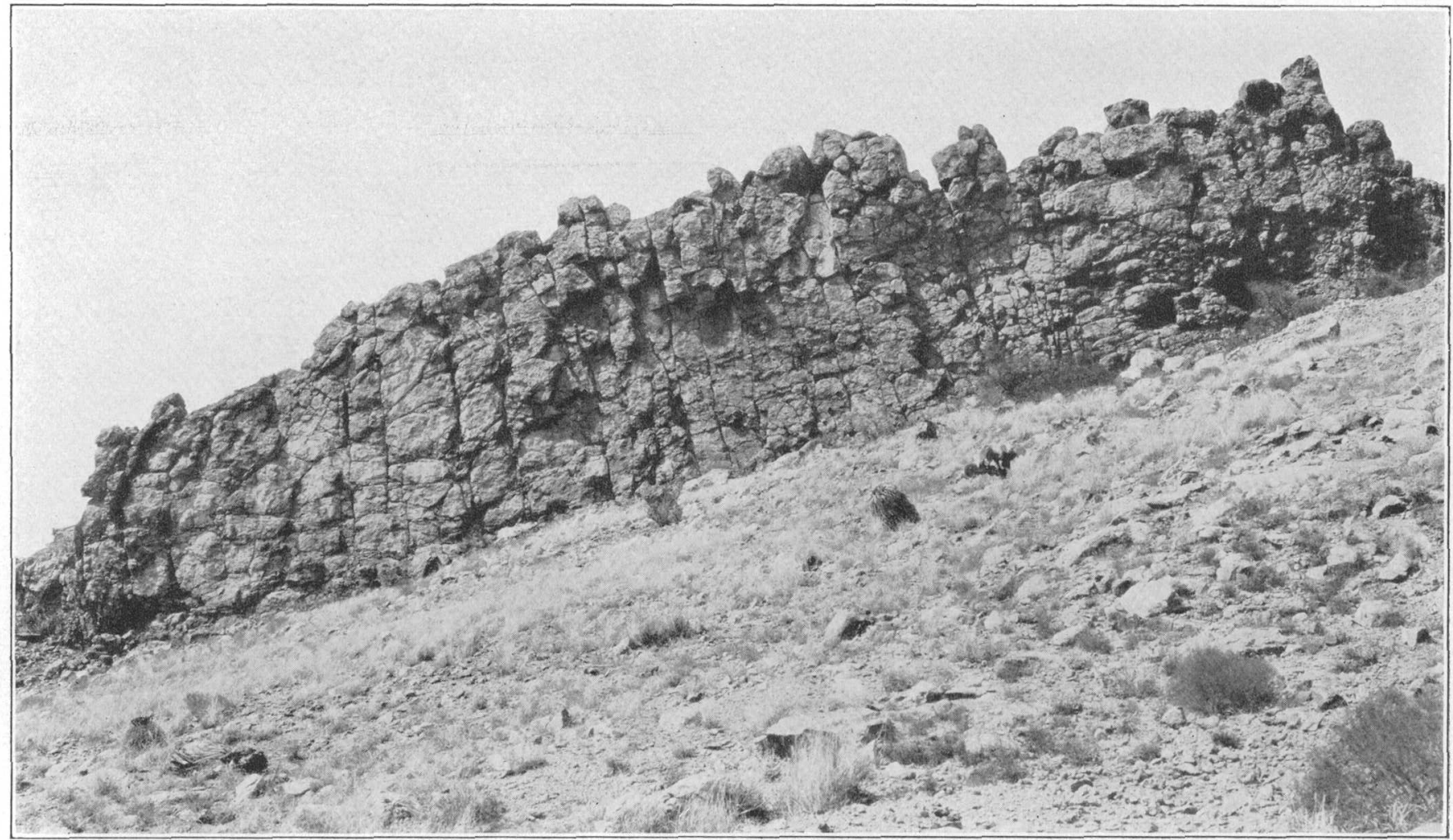

CLOSE VIEW OF ONE OF THE PROMINENT QUARTZ OUTCROPS TYPICAL OF THE ANITA-ATWOOD GROUP OF VEINS. Lone Star claim, just east of Lee Peak. Courtesy of O. E. Mikesell. 


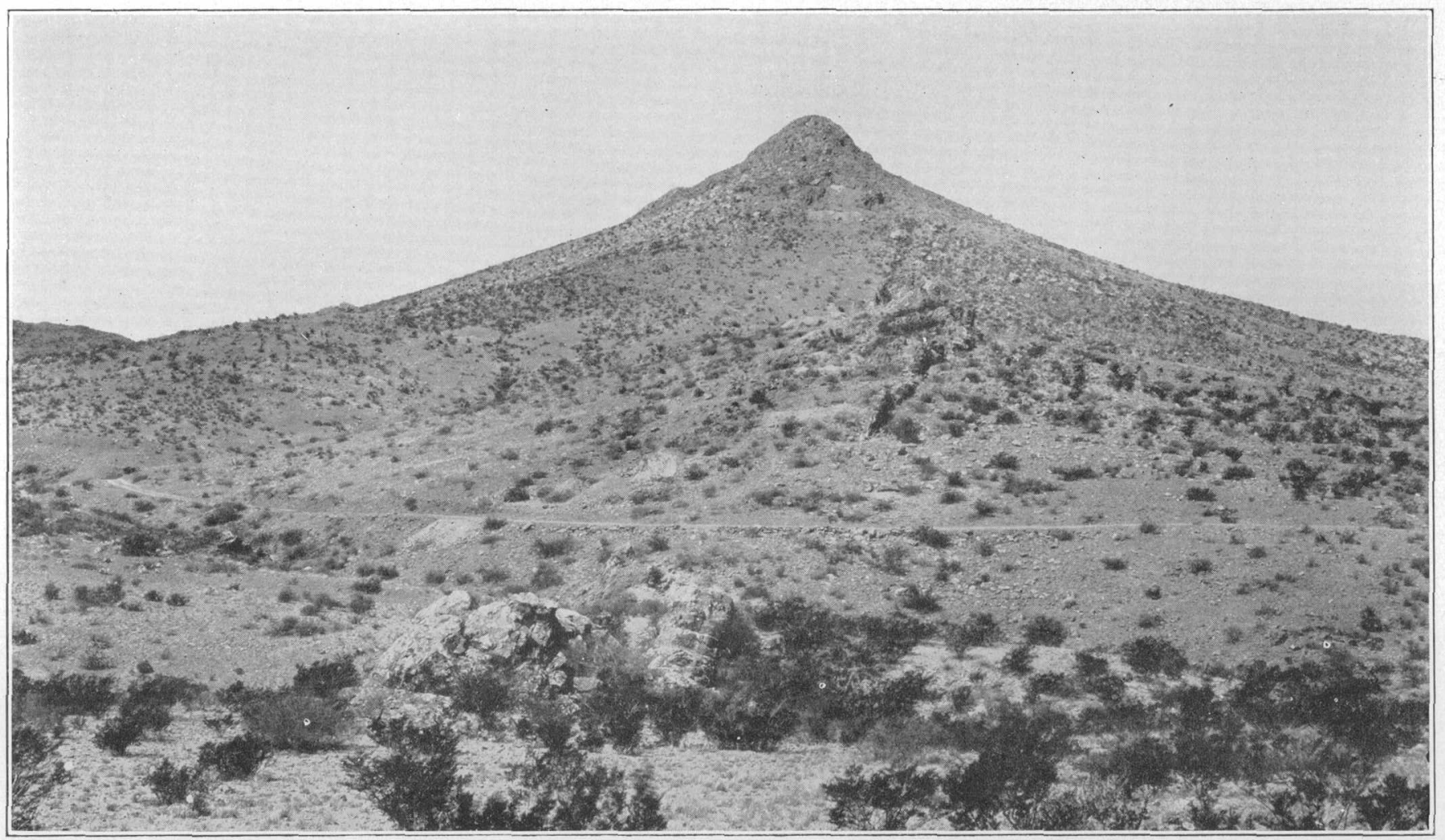

VIEW LOOKING WESTWARD TOWARD LEE PEAK ALONG THE FLORENCE MAY-LONE STAR-SUMMIT VEIN Lee Peak is a massive silicified outcrop at the junction of this vein with several others, one of which can be seen on the southern sky line of the peak. The country rock is lower
basalt. (See pl. 6.) Courtesy of O. E. Mikesell. 
By 1905 the-excitement had died down; development work was in progress at several places, but very little mining was being done. ${ }^{16}$ The best-known properties at that time were the Last Chance, Venus, Nellie Bly, and Robert E. Lee, at Leitendorf; and the Aberdeen, Bonnie, Misers Chest (Lena), Cobre Negra, Superior, Dundee, Atwood, and Eighty-five, in the Virginia area. The Superior and Dundee mines were on the Emerald vein, which has since yielded nine-tenths of the entire production of the district. The production of the district up to that time probably had a value of about $\$ 500,000$.

The Eighty-five claim, which gave its name to the principal mine of the district, was located in January 1885. It was acquired a few year's later by J. A. Leahy and C. F. Dunnegan, of Lordsburg, and in 1906 was sold, with the adjacent claims on the Emerald vein, to a Mr. Black, of Denver. The group was resold in 1913 to the Eightyfive Mining Co., which was organized to acquire the property and which built the town site of Valedon and constructed the railroad spur from Lordsburg. The attention of the new company was directed chiefly to developing the Emerald vein, from which about 100,000 tons of copper ore had already been shipped. A 200-ton mill to concentrate the ore from this mine by gravity and oil-flotation methods was built and was operated from June 1918 to March 1919, but most of the 500,000 tons of ore mined was shipped directly to smelters. On May 1, 1920, the entire property of the Eighty-five Mining Co. was purchased by the Calumet \& Arizona Mining Co. as a source of the siliceous fluxing ore needed for its smelter at Douglas, Ariz. This company increased production, after the depression of 1921 , to an annual average of about 85,000 tons for the next 10 years. On October 1, 1931, the property was acquired by the Phelps Dodge Corporation, which also operated a smelter at Douglas, Ariz., but this company produced from its own mines sufficient fluxing ore to satisfy its needs, and the Eighty-five mine was shut down and the pumps drawn shortly after January 1, 1932. Almost the entire town of Valedon was dismantled and the valuable material salvaged. By that time the mine had become the deepest in the State.

The decrease in the price of copper to 4.75 cents a pound in 1932 and the consequent curtailment of operations throughout the copper industry destroyed the market for the ores of the smaller mines, and by the fall of 1933 the district was deserted except for several prospectors who were hoping to ship a little ore under the new high prices for gold and silver. There was a renewal of operations by lessees in 1934, which was continued on a slightly larger scale in 1935.

\footnotetext{
${ }^{10}$ Graton, L. C., The ore deposits of New Mexico: U. S. Geol. Survey Prof. Paper 68, pp. 332-335, 1910 .
} 
The following table ${ }^{17}$ shows the annual production of the district since 1904:

3ime production of yold, silver, copper, and lead in Lordsburg district, Hidalyo County, N. Mex., 1904-35, in terms of recovered metals

\begin{tabular}{|c|c|c|c|c|c|c|}
\hline Year & $\begin{array}{c}\text { Ore (short } \\
\text { tons) }\end{array}$ & $\begin{array}{l}\text { Gold (fine } \\
\text { ounces) }\end{array}$ & $\begin{array}{c}\text { Silver (fine } \\
\text { ounces) }\end{array}$ & $\begin{array}{l}\text { Copper } \\
\text { (pounds) }\end{array}$ & $\begin{array}{c}\text { Lead } \\
\text { (pounds) }\end{array}$ & $\begin{array}{l}\text { Total } \\
\text { value }\end{array}$ \\
\hline $\begin{array}{l}1904 \\
1906 \\
1907 \\
1909\end{array}$ & $\begin{array}{r}250 \\
366 \\
1,743 \\
5,645 \\
7,532 \\
10,690 \\
29,220 \\
46,139 \\
55,340 \\
31,284 \\
38,964 \\
92,093 \\
118,966 \\
99,532 \\
55,015 \\
77,002 \\
55,307 \\
11,593 \\
61,291 \\
96,587 \\
88,472 \\
108,219 \\
97,420 \\
93,406 \\
91,289 \\
83,091 \\
102,317 \\
96,032 \\
16,608 \\
256 \\
773 \\
1,658 \\
\end{array}$ & $\begin{array}{r}58.4 \\
.5 \\
250.0 \\
423.8 \\
513.6 \\
1,256.9 \\
2,892.7 \\
5,159.1 \\
7,007.6 \\
2,671.9 \\
4,889.7 \\
10,780.3 \\
12,923.3 \\
11,881.2 \\
6,330.2 \\
8,466.0 \\
7,423.7 \\
1,112.0 \\
5,558.8 \\
10,475.8 \\
9.297 .8 \\
10,779.1 \\
11,704.5 \\
9,546.0 \\
10,523.9 \\
10,611.5 \\
14,020.2 \\
11,286.6 \\
1,400.9 \\
105.4 \\
243.9 \\
440.0 \\
\end{array}$ & $\begin{array}{r}2,580 \\
7,584 \\
27,261 \\
33,303 \\
9,889 \\
50,154 \\
130,324 \\
182,448 \\
275,251 \\
154,779 \\
232,647 \\
374,325 \\
373,074 \\
295,443 \\
153,236 \\
242,733 \\
182,000 \\
35,119 \\
107,511 \\
141,538 \\
113,591 \\
126,781 \\
126,909 \\
77,155 \\
104,653 \\
159,163 \\
189,070 \\
137,731 \\
36,858 \\
1,820 \\
2,998 \\
11,370 \\
\end{array}$ & $\begin{array}{r}18,200 \\
48,000 \\
212,601 \\
463,335 \\
259,079 \\
589,969 \\
1,627,591 \\
2,455,336 \\
3,155,585 \\
1,601,461 \\
2,614,674 \\
3,890,365 \\
4,755,179 \\
4,261,956 \\
2,214,996 \\
3,516,457 \\
2,695,674 \\
579,295 \\
3,216,585 \\
4,314,122 \\
4,927,878 \\
5,054,140 \\
4,762,750 \\
3,933,496 \\
4,625,347 \\
4,248,193 \\
4,857,300 \\
3,991,700 \\
858,000 \\
21,000 \\
27,950 \\
78,000 \\
\end{array}$ & $\begin{array}{r}12,000 \\
10,522 \\
11,373 \\
8,862 \\
19,662 \\
2,157 \\
4,562 \\
14,572 \\
30,049 \\
28,723 \\
30,478 \\
41,442 \\
17,831 \\
53,264 \\
98,312 \\
13,134 \\
102,291 \\
46,185 \\
40,412 \\
49,700 \\
73,400 \\
46,381 \\
19,638 \\
59,080 \\
88,300 \\
96,700 \\
31,800 \\
19,000 \\
19,200 \\
28,100 \\
\end{array}$ & $\begin{array}{r}\$ 5,550 \\
12,124 \\
64,737 \\
122,646 \\
50,534 \\
129,140 \\
337,742 \\
510,359 \\
835,015 \\
397,588 \\
578,658 \\
1,094,795 \\
1,684,508 \\
1,656,130 \\
832,464 \\
1,103,753 \\
855,710 \\
133,426 \\
662,287 \\
970,024 \\
917,094 \\
1,035,981 \\
993,802 \\
759,290 \\
945,959 \\
1,055,597 \\
998,479 \\
640,080 \\
94,336 \\
4,863 \\
13,408 \\
31,169 \\
\end{array}$ \\
\hline $1904-35$ & $1,674,100$ & $190,035.3$ & $4,099,298$ & $79,886,214$ & $1,117,130$ & $19,527,248$ \\
\hline
\end{tabular}

The Lordsburg district has yielded over nine-tenths of the metals produced from Hidalgo County since mining in the county begar. The Emerald vein alone has yielded nine-tenths of the ore mined in the district and therefore more than eight-tenths of all that mined in the county. In the period from 1904 to the shut-down of the Eighty-five mine at the end of 1931 the value of metals produced from the Lordsburg district was 5.6 percent of the value of the entire production of New Mexico; the district in that period produced 5.7 percent of the copper mined in the State, 15.4 percent of the silver, 22 percent of the gold, and 0.5 percent of the lead. The average annual output of ore for that period was 59,000 tons. The largest annual output was 118,966 tons in 1916, during the World War. There was no market for the siliceous ore of the district in 1921, because of curtailment at nearby smelters, and production for that year was only 11,593 tons. Normal operations were resumed the following year, and the average annual production from then until the end of 1931 was 92,000 tons, having an average annual value of $\$ 900,000$. 
The following list gives the names of claims from which ore i.s known to have been shipped:

$\begin{array}{ccc}\text { Eighty-five group: } & \text { Anita group: } & \text { Others: } \\ \text { Superior. } & \text { McGinty. } & \text { Ruth. } \\ \text { Emerald. } & \text { Lucy. } & \text { Ada Etta. } \\ \text { Dundee. } & \text { Ontario. } & \text { Battleship. } \\ \text { Rockford. } & \text { Atwood group: } & \text { Victoria. } \\ \text { Eighty-five. } & \text { Atwood. } & \text { Eldorado. } \\ \text { Nevada. } & \text { Henry Clay. } & \text { Green King. } \\ \text { Carrie. } & \text { Triangle. } & \text { General Jerry Boyle. } \\ \text { Cobre Negra. } & \text { Southern. } & \text { Goodsight. } \\ \text { Bonney group: } & \text { Leitendorf camp: } & \text { Waldo. } \\ \text { Bonney. } & \text { Last Chance. } & \text { Hobson. } \\ \text { Lone. } & \text { Venus (Viola). } & \\ \text { Cochise. } & \text { Robert E. Lee. } & \\ \text { Shoo-fly. } & \text { Nellie Bly. } & \\ & \end{array}$

\section{FORM AND STRUCTURE OF THE DEPOSITS}

The ore deposits of the Lordsburg district are veins that lie along. the fault fissures already described. The faults are mineralized nearly everywhere, so that the vein system practically coincicles with the fault system and contains two major groups, one trending northeastward and the other eastward. The Emerald vein of the northeastward-trending group has been traced on the surface for more than 6,000 feet and has been mined, at the Eighty-five mine, from the surface continuously for a vertical depth of 1,900 feet and for an average of nearly 2,000 feet along the strike. The Bonney vein, of the same group, has been mined to a depth of 675 feet. Several other veins have been explored to depths of 750 feet or less, but only a little ore has been developed in them; these include the Atwood (Alamo) and Anita veins of the eastward-trending group and the Misers Chest vein of the other group.

Many of the veins, particularly those of the eastward-trending Anita-Atwood set, tend to form prominent, wall-like outcrops that stand many feet above the surrounding surface. (See pls. 2, 6, and 7.) Outcrops 30 feet wide and 15 feet high are common; that at Lee Peak, as shown in plate 7 , is 125 feet across and stands 60 feet above the surrounding rock. Ledges 2 or 3 feet wide and 6 to 10 feet high stand up as sharply as man-made walls. These resistant outcrops are in part quartz vein filling and in part wall rock that has been made resistant by partial silicification.

In detail the veins show several features that are important to the miner. Branches, some of which rejoin the main vein, are common. At places the veins split into several members, as if fraying out, but one of these members strengthens farther on and becomes the main vein, or the vein is taken up by another fissure somewhere 
in the wall. At many other places the vein filling lies in overlapping simple fissures or crosses along a link from one fissure to a parallel one, the main fissures continuing as tight or gouge-filled, nearly barren stringers. It is common for two such gouge-filled stringers to pass into a quartz vein at their junction, the quartz widening to several feet within a short distance. Similar features are shown in cross section. Figure 6 illustrates these details and shows the scale on which they occur.

Post-ore faulting has occurred along all veins, forming thick masses of gouge and breccia. Movement was largely confined to planes that lie within or along the walls of the veins, and although bulges and undulations of the veins have longitudinal slices faulted from them, displacement is so nearly parallel to the vein that the continuity of ore is not seriously interrupted. Vein walls are weakened where a post-ore fault passes into them, and it has been the experience at the Eighty-five mine that as a result of this weakening the ore is generally diluted about 20 percent in the course of mining because of unavoidable inclusion of wall rock. At some places in the mine a cut-and-fill system of mining had to be employed instead of the cheaper shrinkage system generally used, in order to minimize the dilution.

\section{VEIN FILLING}

\section{GENERAL FeATURES}

The veins are chiefly fissure fillings along fracture zones that were repeatedly and spasmodically reopened during mineral deposition, as shown by several stages of brecciation and recementation of the vein matter. Each reopening was accompanied by a distinct change in the character of the material deposited, and as a result there are shoots in which a particular variety of filling predominates. (See pl. 13.) The mineral succession, however, is similar to that commonly shown in deposits in which deposition was uninterrupted, and the several stages of deposition and reopening clearly seem to have been parts of an essentially continuous process of vein formation. Only one stage, the second, yielded exploitable ore deposits; minor amounts of copper, lead, gold, and silver were deposited during later stages, but dilution caused by valueless gangue minerals of those stages more than offsets the gain.

At no stage of mineralization except possibly the first were the fissure openings and breccia interstices completely filled, and the composite vein filling is generally a highly vuggy and drusy mass that contains breccia fragments of altered wall rock and of vein matter. (See fig. 7 and pl. 8, B.) Some of the larger openings along 


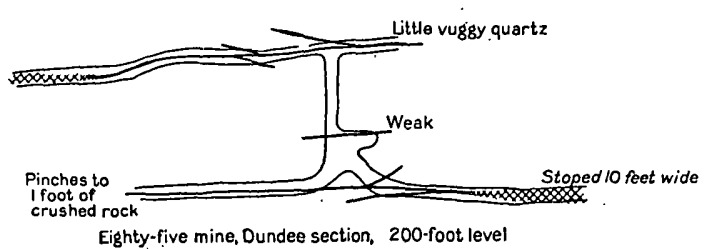

Eighty-five mine, Dundee section, 200-foot level

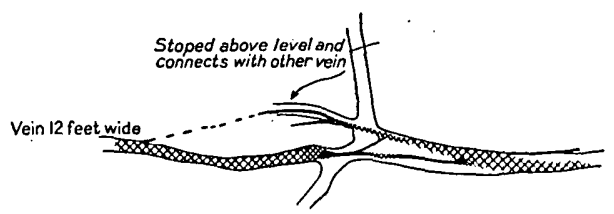

Eighty-five mine, Jim Crow section, 900-foot level

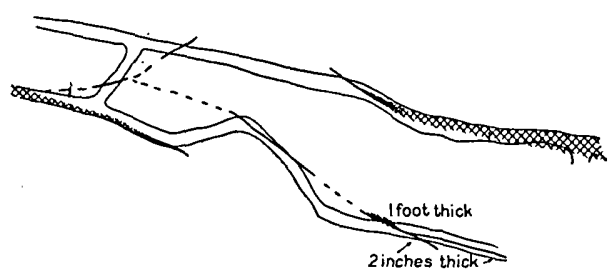

Eighty-five mine, Dundee section, 1200 -foot level

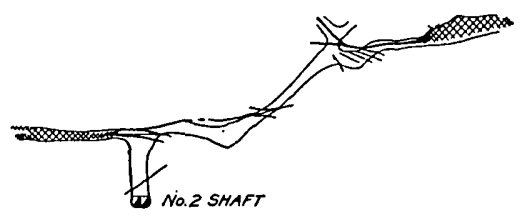

Bonney mine, 600 -foot level

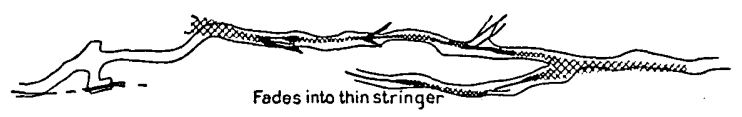

Anita mine, 500-foot level

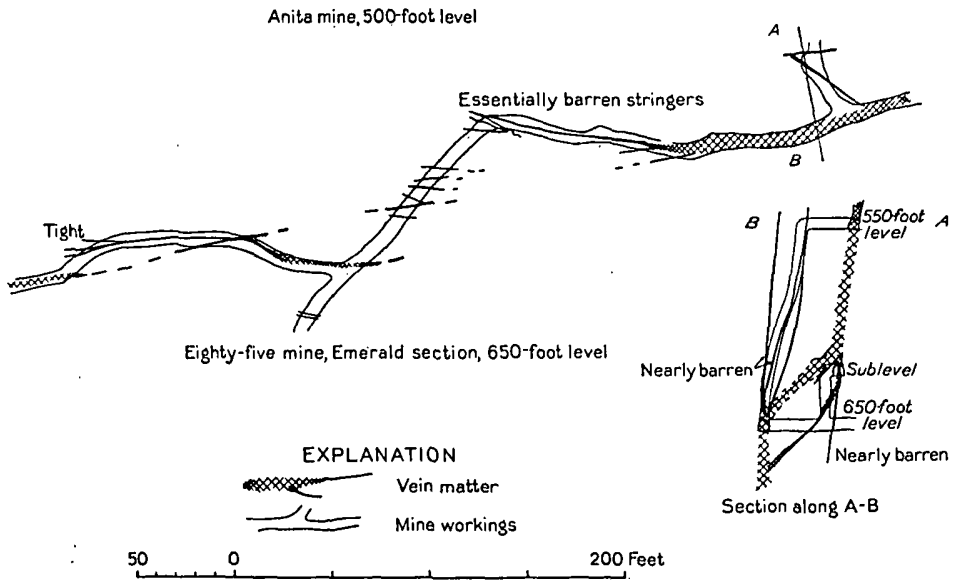

Frgure 6.-Details of veins in the Lordsburg mining district. 
the walls are the result of the leaching or flushing out of finely comminuted fault matter, and in parts of the veins there was a stage of hydrothermal leaching during which breccia fragments and slivers of altered wall rock were removed, leaving behind a boxwork composed of thin, rigid walls of vein matter perfectly preserving the shape of the leached fragments.

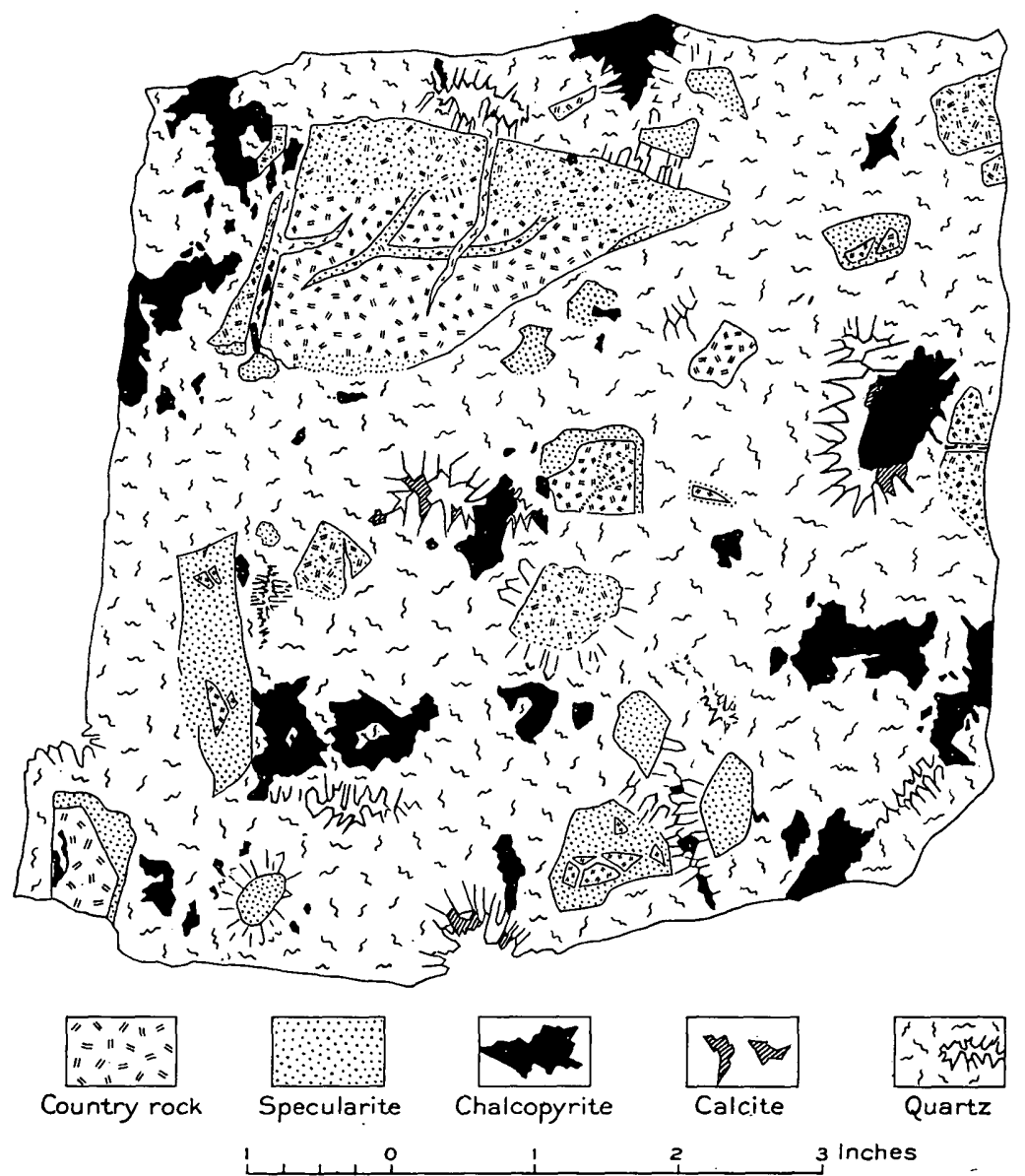

Figure 7.-Drusy breccia ore, Lordsburg mining district. Drawn from a specimen. Shows fragments of country rock veined, cemented, and replaced by specularite and fragments of both country rock and specularite veined, cemented, and replaced by drusy quartz and chalcopyrite. A little calcite crusts the quartz and chalcopyrite in some of the druses.

Figure 8 graphically summarizes the several stages of mineralization and the relation of mineral deposition to other events. The detailed descriptions of these stages, as given in the following pages, are based in large part on a study of the Emerald vein. Simple features that seem characteristic of smaller veins are duplicated in the Emerald vein and are only the results of temporary phases of 
an extended period of mineralization. The Emerald vein contains minerals of all but the last stage, and the approximate average mineral composition of the ore shoots, as computed from detailed mine records, is given in the following table. A little asbestos (mountain leather variety) was found at one place in the vein.

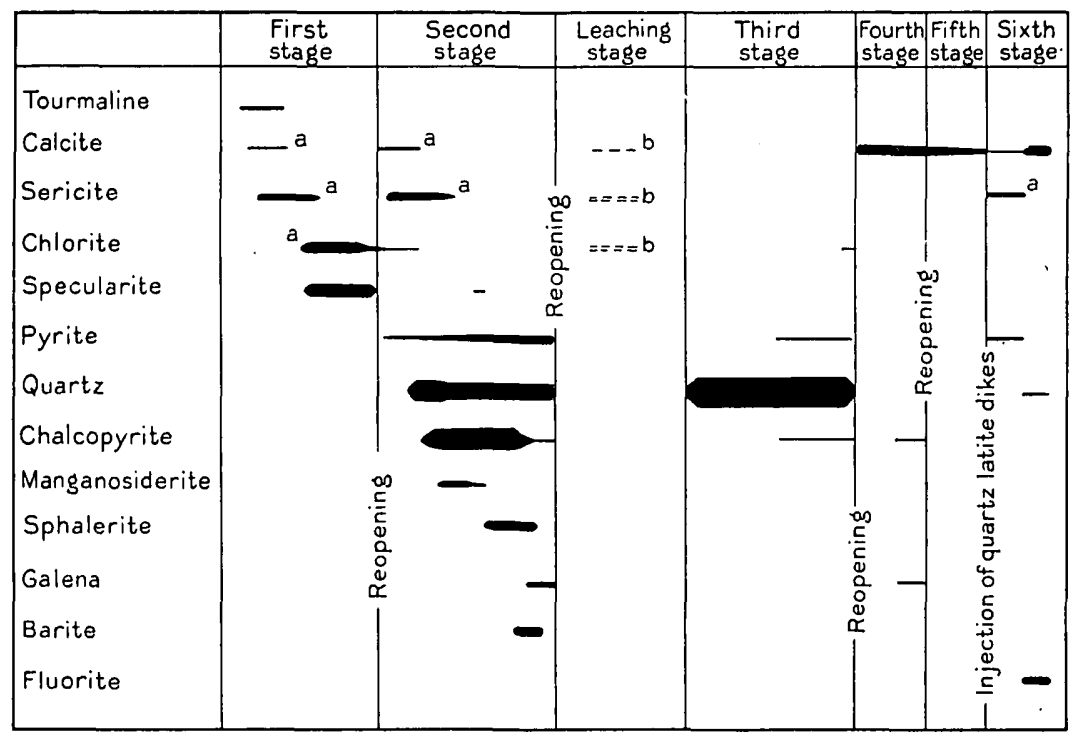

Figure 8.-Mineral succession in the Lordsburg district and the relation of mineral deposition to other events. Average composition of the ore shoots: Quartz, 68; sericite and chlorite, 8 ; calcite, 5 ; tourmaline and barite, 3 ; manganosiderite, 0.5 ; chalcopyrite, 8 ; pyrite, 4 ; specularite, 2 ; sphalerite, 1 ; galena, 0.5 percent. $a$, In the wall rocks only; $b$, leached out.

Fluorite was found at four places in the district but not in any of the major veins. Smelters report that the ores of the district contain a trace of bismuth.

\section{Mineral composition of ore shoots in the Emerald vein}

Gangue minerals:

Percent

Quartz

6S. 0

Sericite and chlorite, in breccia fragments and interfissure masses of altered wall rock.

Calcite

Tourmaline and barite.

Manganosiderite

Ore minerals:

Chalcopyrite

Pyrite

Specularite

Sphalerite

Galena 
The average primary ore as mined from the Emerald vein contained 2.8 percent of copper and 1.23 ounces of silver and 0.111 ounce of gold to the ton. Mining was stopped in general where the copper content of the ore dropped below 2 percent, though some ore containing as little as 1 percent of copper was mined. The grade of ore mined and the ratio between the different metals were remarkably uniform, and it is an impressive fact that the very roots of the main shoot in the Emerald vein are almost identical in grade with the average of the 850,000 tons of ore last mined.

\section{FIRST STAGE OF MINERALIZATION}

The mineralization of the first stage consisted of the formation of sericite, chlorite, and calcite in the wall rocks, local impregnation of the wall rocks by tourmaline and specularite, and deposition of tourmaline and specularite in the vein openings. The veins affected by the mineralization of this stage include the Emerald, Bonney, Atwood, and Anita veins, those in the granodiorite south of the Tioga claim, the Copper Reef vein, and the several veins in the southwest corner of the mapped area.

Specularite is much more widely distributed than tourmaline, but where either is prominent the other seems to be absent. 'The tourmaline is brown to green and forms tufts of radiating needles as much as half an inch in length. It occurs chiefly in or near the granodiorite. It tends to line the vein walls, eating into the adjacent rock, and in places forms a fairly massive replacement band several inches thick. At such places the residual rock matter was commonly later silicified, and the rock now consists of tourmaline, quartz, and a few disseminated grains of sulphides. Threads and stringers of tourmaline cut the rock nearby. Uninterrupted tourmalinization of the wall rock extended a maximum of 10 feet from the vein walls, but disseminated tufts are present as much as 200 feet away: (See pl. 8, A.)

In the wall rocks the tourmaline replaces quartz as well as the aluminous minerals and is associated with a little sericite and calcite. The sericite is very fine grained and pale greenish, and in the granodiorite it is invariably more common in the oligoclase phenocrysts than in the orthoclase of the groundmass.

'Two varieties of specularite are present in the vein filling. A moderately magnetic variety is very prominent as the first coating on breccia fragments of rock and filling cracks in these fragments and as veinlets penetrating the walls. (See fig. 7.) A soft, unctuous nonmagnetic variety, loosely adherent and called "graphite" by the miners, is very abundant locally. Both varieties are extremely fine grained; the largest plates observed are only about 1 millimeter in diameter, and most plates are less than half that size. 


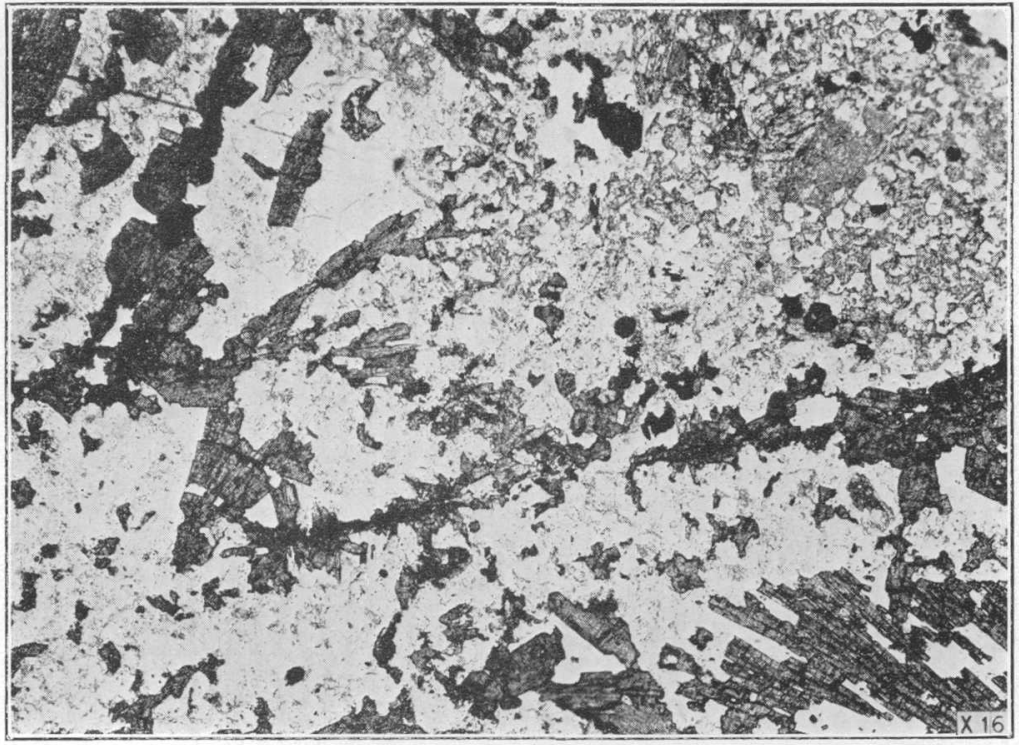

A. PHOTOMICROGRAPH OF TOURMALINIZED GRANODIORITE.

Groundmass consists of quartz and orthoclase (both white) and subordinate sericite (mottled). Plain transmitted light.

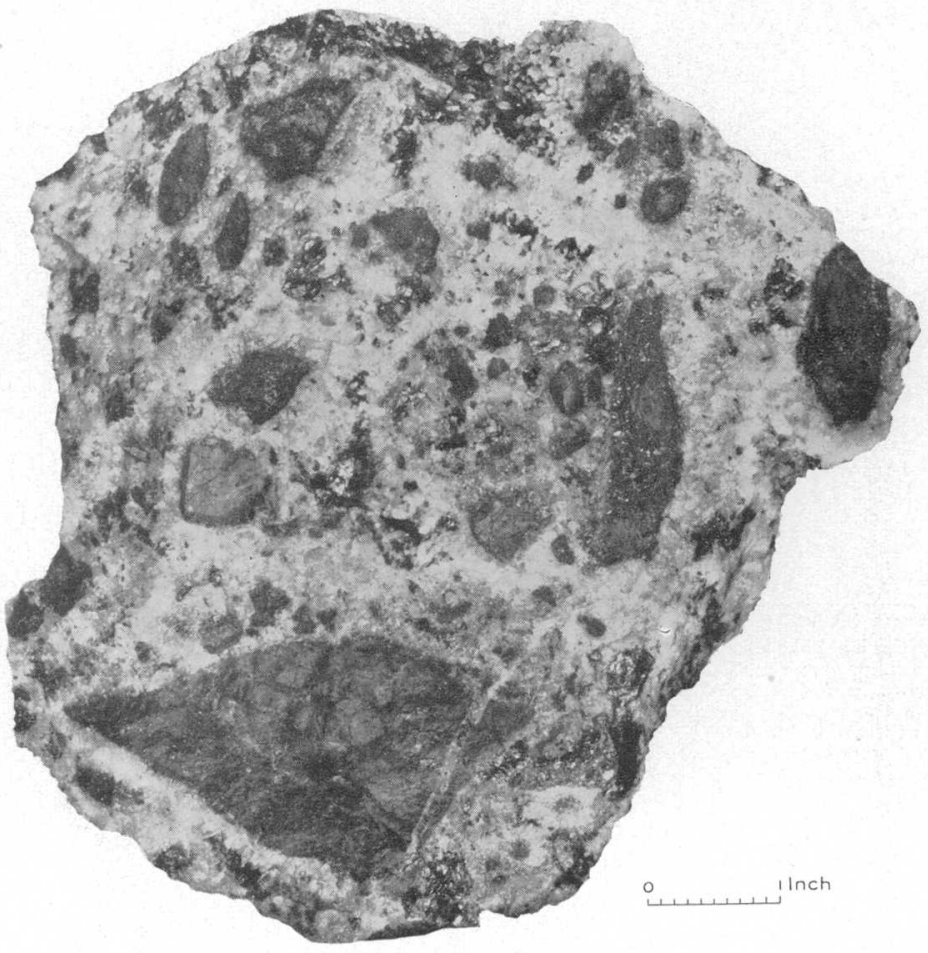

A. DRUSY BRECCIA ORE FROM THE EIGHTY-FIVE MINE. 


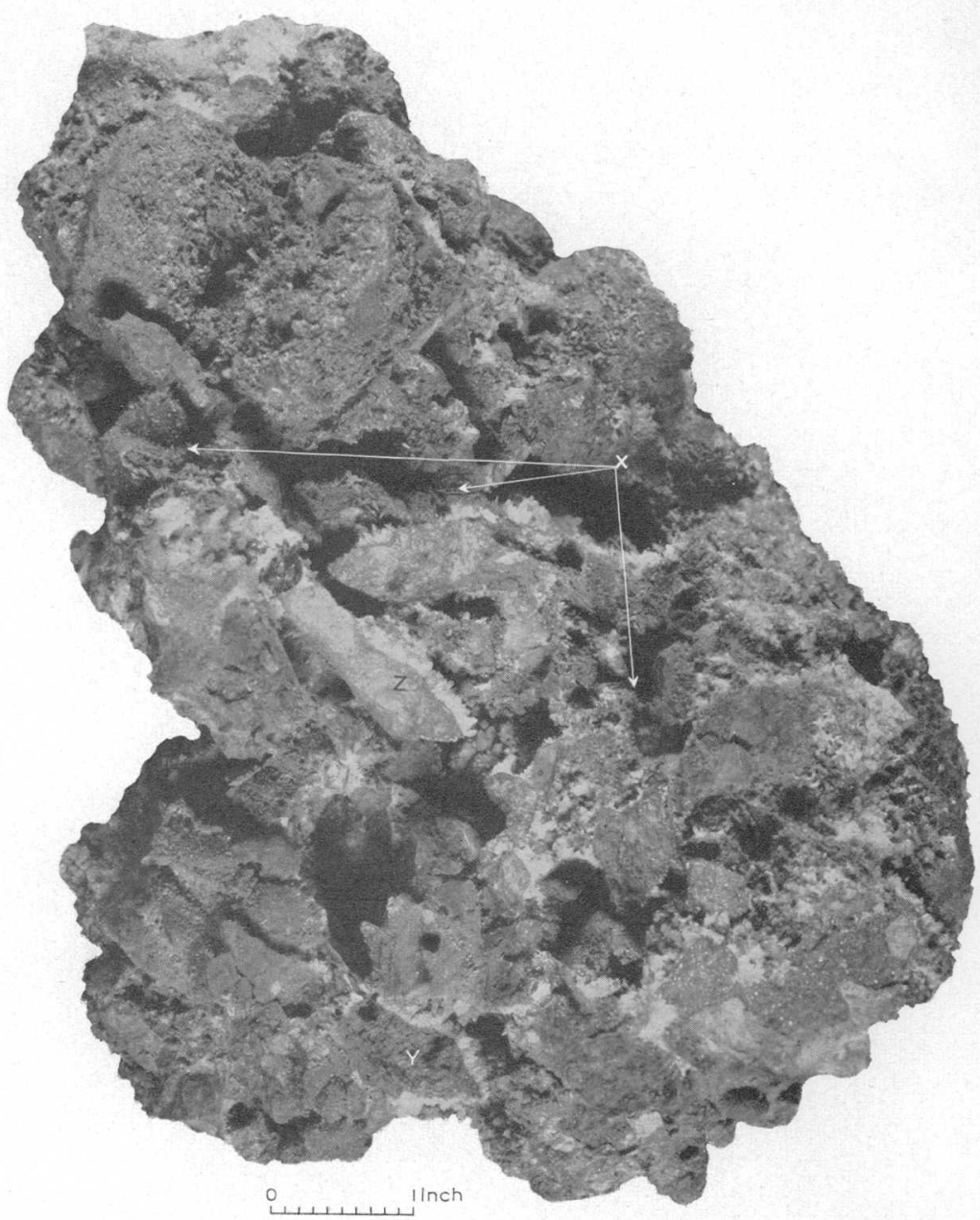

BRECCIA ORE FROM WHICH MOST ROCK FRAGMENTS HAVE BEEN LEACHED.

Probably the leaching was done by solutions that later deposited the minerals of the third stage. The honeycombed mass consists of specularite, quartz, chalcopyrite, a little barite, and some residual rock. The photograph does not show the essential features as clearly as the specimen itself, but the angular shape of the cavities and the ribs of vein matter penetrating them can be seen. The ribs are well shown at the place marked $X$. At $Y$ the grains of quart $\%$ and specularite that impregnated the breccia fragment were sufficiently abundant to support one another after the rock matrix was removed; compare this fragment with that at 7 . Eighty-five mine. 


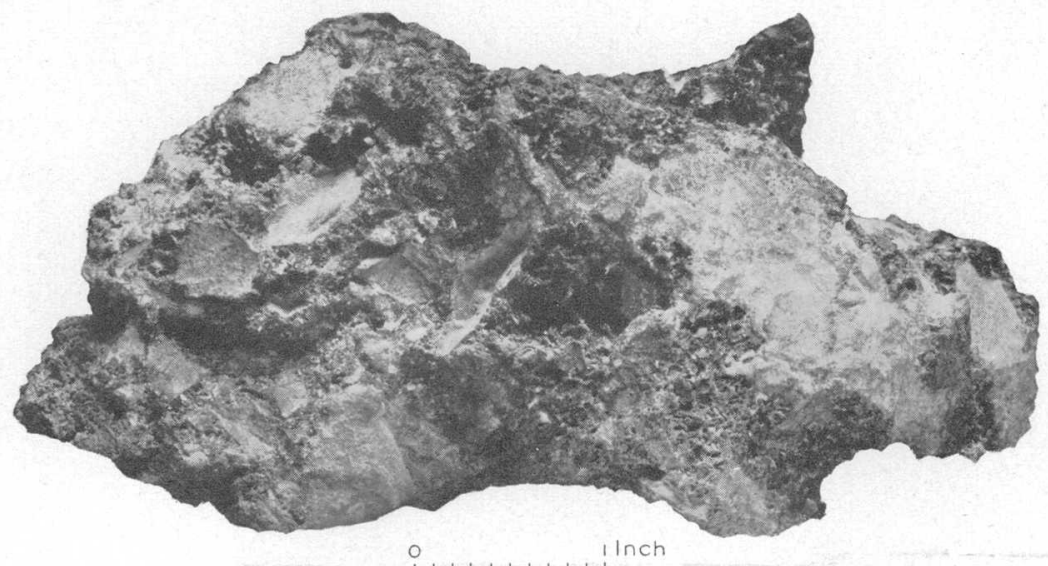

A. FINE-TEXTURED HONEYCOMB OF QUARTZ, SPECULARITE, AND CHALCOPYRITE

Produced by hydrothermal leaching of the rock in whicn these minerals were distributed. Note the "gnawed" outlines of some of the rock pieces and the incipient honeycomb in the upper part of the breccia fragment at the right. Bonney mine. (See pl. 11, A.)

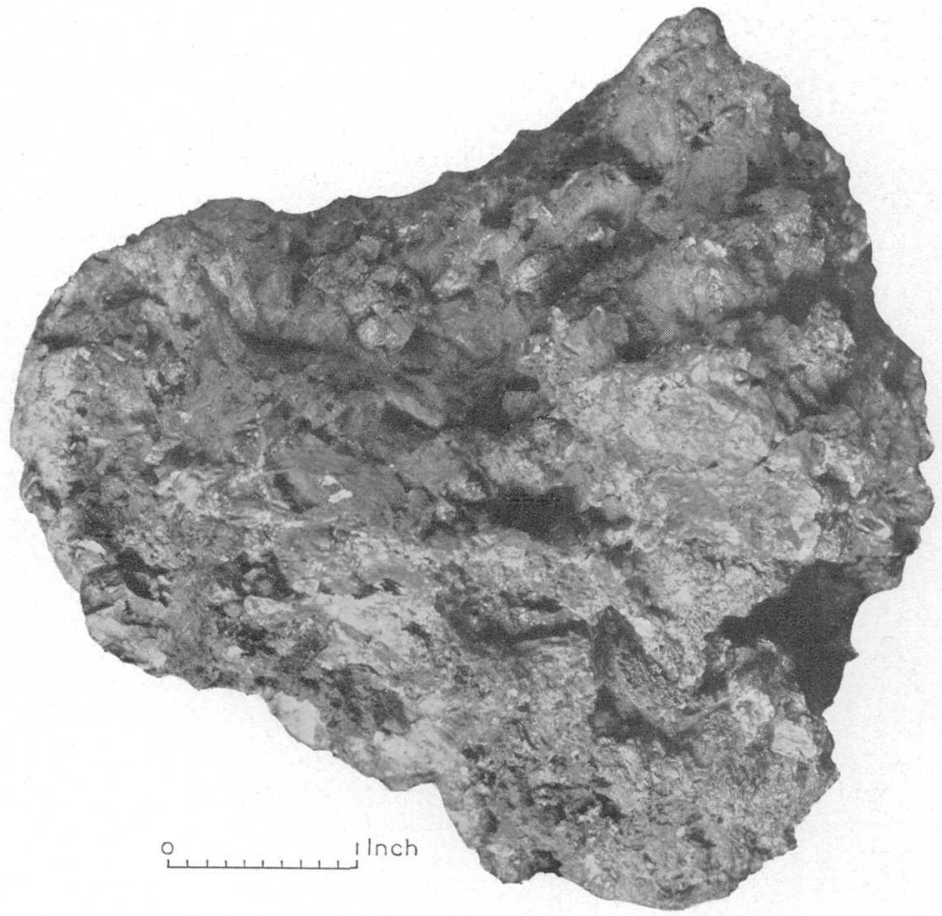

B. POROUS, "WORM-EATEN" CHALCOPYRITE AND SPHALERITE FROM WHICH INTERSTITIAL ROCK MATTER HAS BEEN LEACHED.

Bonney mine. 


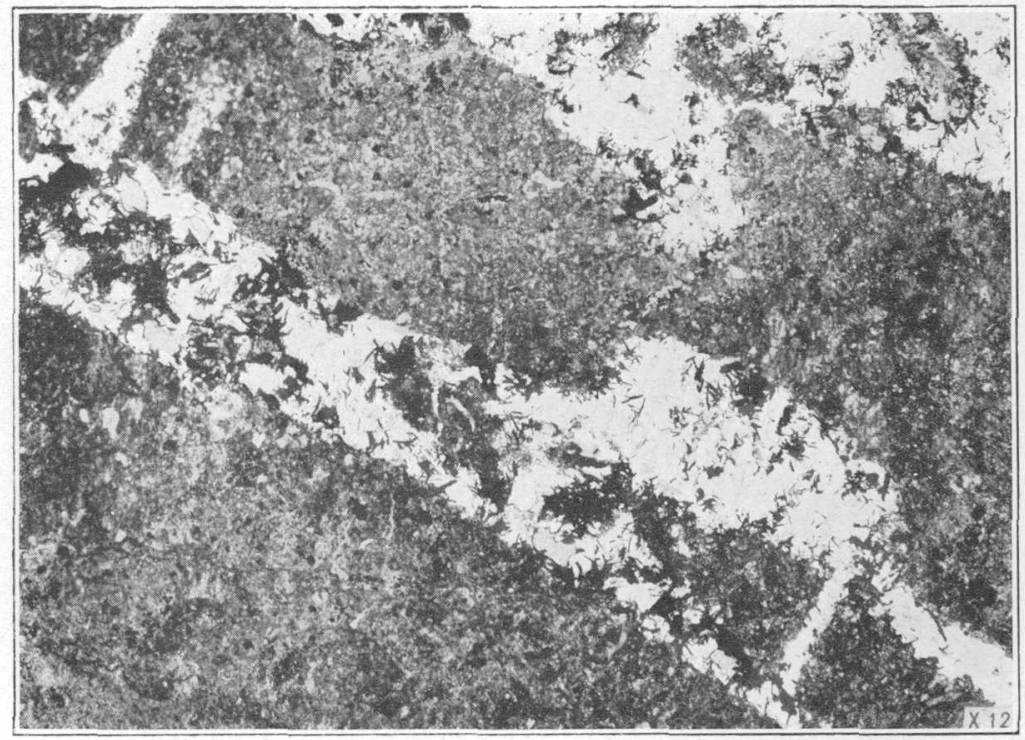

A

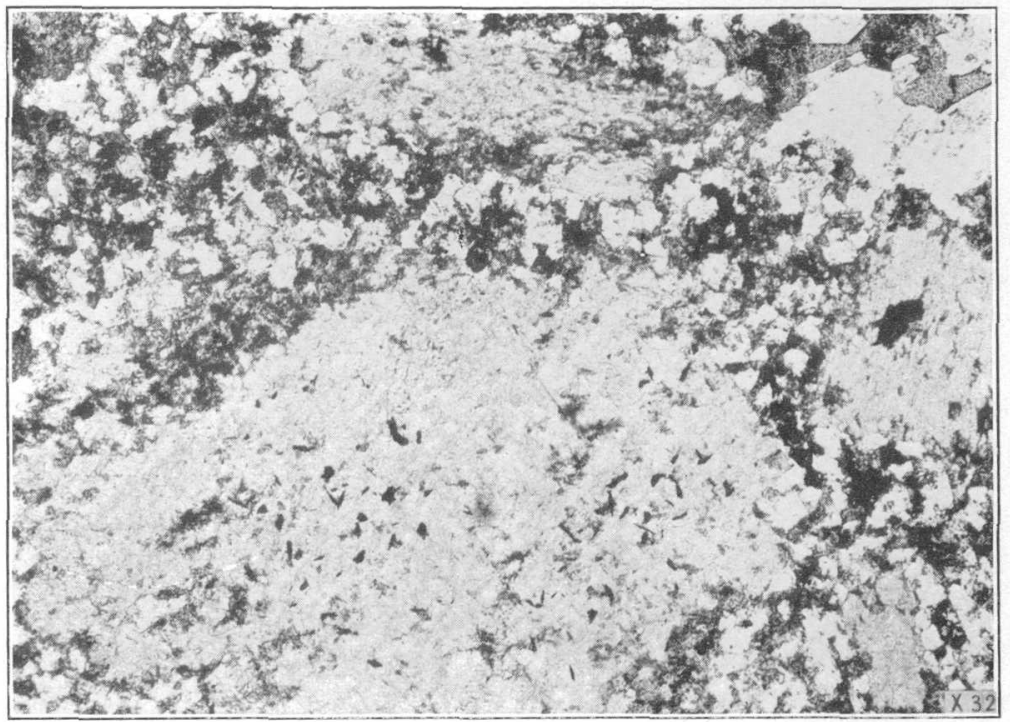

B

PHOTOMICROGRAPHS SHOWING NATURE OF THE ALTERED ROCKS THAT YIELDED, AFTER LEACHING, THE HONEYCOMBS SHOWN IN PLATES 9 AND 10.

A. Chloritized, sericitized basalt cut by stringers of quartz and specularite, which form the walls of the honeycombs af ter the rest of the rock is removed. A few grains of specularite and quartz are distributed in the rock matter. The mottled gray in the veined parts is bakelite, with which the section was cemented to permit grinding. The thin section from which this photograph was taken was cut from the specimen illustrated in plate $10, A$. Plain transmitted light.

$B$. Altered granodiorite. The original plagioclase phenocrysts are replaced by sericite (light-gray felted areas); the nonquartzose parts of the groundmass are replaced by chlorite and very subordinate sericite (speckled dark interstitial material); and the rock is impregnated with specularite (black), which is confined largely to the chloritic groundmass. Clear white material is residual quartz. Plain transmitted light. 
Specularite is common in the wall rocks except where tourmaline is prominent, and where specularite is present the rock is also strongly chloritized. The altered basalt at those places differs physically from the fresh rock only in being softer and duller, but the specularite-impregnated granodiorite has a distinctive appearance. It is greenish black and contains pale-greenish sericite pseudomorphs of the original plagioclase phenocrysts that stand out clearly from a black and green groundmass. The sericite is the fine-grained variety that is associated with the tourmaline. The nonquartzose parts of the groundmass are replaced completely by chlorite and by subordinate sericite, and the chloritic parts contain abundant clusters and plates of specularite. (See pl. 11, B.) The chlorite encroaches upon the sericite pseudomorphs, which contain a little chlorite and a few plates of specularite and which are traversed by threads of specularite and of chlorite. The distinctive appearance of the rock extends a maximum of 3 feet from the vein walls.

\section{SECOND STAGE OF MINERALIZATION}

The veins were sheeted and in part brecciated after deposition of the specularite of the first stage, and the ensuing deposition consisted of quartz accompanied at first by a trace of chlorite, then by considerable chalcopyrite and a little manganosiderite, and still later by sphalerite and minor amounts of galena and barite. A little pyrite was deposited during most of this period, and locally there was a slight recurrence of specularite deposition. Wall-rock alteration consisted chiefly of sericitization and silicification, which partly destroyed the earlier specularite and tourmaline.

The preparatory sheeting of the earlier specularite veins and of the adjacent wall rocks is a very common feature, the joints and fissures being filled with quartz and chalcopyrite. The interfissure material ranges from bands several inches across and cut by stringers of quartz and sulphides down to thin ribs less than a millimeter thick upon both walls of which are intergrowths of sulphides and comb quartz. Breccia fragments of wall rock and of specularite are prominent locally in the vein filling. (See fig. 7 and pl. 8, $B_{i}$ )

The quartz of this period is generally white and coarse-grained but includes fine-grained sugary aggregates and colored horny or cherty varieties. It forms combs of crystals projecting from vein walls, radiating outward from included breccia fragments, and lining residual cavities. The dense and horny varieties are gray, red, and green and grade locally into one another. They appear as streaks within the veins, as patches with indistinct outlines, and as sharply outlined breccialike pieces and consist largely of silicified rock containing drusy shrinkage carities. The red varieties contain residual specularite and a reddish-brown dust, the green varieties are inter- 
growths of microcrystalline quartz and chlorite, and the gray varieties contain sericite and pyrite. Some of the green chert may be the result of contemporaneous deposition of chlorite and quartz. All varieties contain threads and minute pockets of chlorite, which are later than the cherty silicification, later than the chlorite of the green chert, and later than the specularite and red dust of. the red chert. None of the chlorite threads extend beyond the limits of the chert; some of them have quartz centers, and they are crossed and replaced by stringers and patches of all the characteristic vein minerals of this stage.

Manganosiderite is common in small quantities in the western part of the Eighty-five mine and has been found on some of the dumps at Leitendorf. Probably it is sparingly present at other places. Some of it may have been removed from the veins by the leaching solutions that followed this stage of deposition. (See p. 37.) It is fine-grained and faintly pink and, according to a partial analysis by T. C. Bunch, of the New Mexico School of Mines, contains about 56 percent of $\mathrm{FeCO}_{3}$ and 43 percent of $\mathrm{MnCO}_{3}$. It is intimately mixed with quartz in patches that are sprinkled with pyrite and embedded in mixtures of quartz and sulphides. It also fills residual cavities in quartzchalcopyrite stringers.

White and pink barite is widely distributed in small amounts and is fairly abundant at places. The plates are small, generally less than half an inch in length. The barite is associated with galena and sphalerite and in part is intergrown with those minerals, though some galena penetrates along cleavage planes of the barite, and in places the barite encloses small masses of sphalerite that seem to be breccia pieces.

Coarse-grained chalcopyrite is the most abundant and the earliest sulphide of this period. Masses of nearly solid chalcopyrite as much as 10 or 15 feet long and 3 feet thick are present, and sphenoidal crystals as much as $1 \frac{1}{2}$ inches across project into some of the drusy cavities. (See fig. 7.) Elsewhere irregular blebs of chalcopyrite are intergrown with the quartz, and minor amounts are intergrown with the other sulphides; particles are sciattered in the wall rock adjacent to the veins, and some breccia fragments of altered wall rock are largely replaced by it. An assay of one specimen of chalcopyrite showed 0.22 ounce of gold and 2.20 ounces of silver to the ton.

Some of the specularite of the first stage is cut by stringers of chalcopyrite and impregnated with shotlike pellets of it, but some specimens show chalcopyrite crystals coated with quartz needles that are colored deep red by specularite, indicating a recurrence of specularite deposition.

Sphalerite and galena are fairly evenly distributed in the metalliferous parts of most veins of the district, and a little ore has been 
shipped for its lead or zinc content. Polished specimens of ore show that the sphalerite and galena are in part contemporaneous and were deposited near the end of the chalcopyrite stage. (See fig. 8.) Most of the sphalerite is yellowish brown, but it grades into a black variety on the one hand and into a nearly white variety on the other, though without apparent geologic control. None of it contains the disseminated particles of chalcopyrite that are common in the sphalerite of other Western ore deposits. An assay of one specimen showed 0.07 ounce of gold and 3.25 ounces of silver to the ton.

Small crystalline grains and clusters of pyrite are scattered here and there in the quartz and in the wall rock and are associated with the other sulphides, particularly with sphalerite and galena.

Wall-rock alteration accompanying this stage of mineralization consisted of sericitization and subordinate calcitization followed by silicification. Distinctive alteration extended not more than 15 feet from the vein walls. In this as in the preceding stage, the sericite replaced the plagioclase of the granodiorite in preference to the orthoclase, and toward the outer edge of the zone of alteration the granodiorite contains greenish sericite pseudomorphs in a matrix of pink and comparatively fresh orthoclase. The sericite foils are much larger than those formed during the preceding stage, some of them reaching 0.5 millimeter in diameter.

The sericite replaced the tourmaline of the preceding stage, and where sericitization was intense, as at the vein walls, only a few microscopic residuals of tourmaline are left. Later silicification replaced the sericite without greatly attacking the tourmaline. A large part of the rock that had been impregnated with chlorite and specularite was bleached out during this stage of mineralization, a feature that is strikingly apparent at some places. The bleached rock generally has considerable pyrite, a little of which is pseudomorphic after the specularite, and the chlorite is replaced by coarse foils of sericite and by calcite. The specularite was preserved at many places, however, and has given the red color to some of the silicified rock. In general the specularite seems to have been comparatively stable in the presence of the sulphide-depositing solutions. Included blades of specularite are common in the massive chalcopyrite, but in none of the polished specimens examined does the specularite show more than moderate corrosion. Where both altered wall rock and specularite are present, the chalcopyrite seems to have replaced the wall rock in preference to the specularite.

\section{HYDROTHERMAL LEAC.HING}

Between the second and third stages of deposition parts of the veins were traversed by solutions that removed chlorite, calcite, and 
sericite from breccia fragments and slivers of altered wall rock, from interstitial rock matter in masses of replacement sulphides, and from some of the cherty silicified rock, leaving behind porous honeycombed masses of first- and second-stage minerals. The veins had been reopened after the second stage of deposition, as shown by breccia fragments cemented by later filling and by distinct veins of this later material cutting vein matter of the earlier stages, and presumably it was this reopening that gave access to the leaching solutions. The reopening may have started near the beginning of the galena-barite phase of the second stige, because here and there galena-barite intergrowths enclose small masses of sphalerite that seem to be breccia pieces.

In the leached breccia ore the cavities have the size and angular shape of the breccia pieces and are penetrated by rigid paper-thin ribs of vein matter. These ribs evidently were veinlets that originally cut the rock pieces, and the cavities seem to be perfect casts of such veined fragments as are pictured in figure 7 and plate $8, B$. The walls of some cavities are marked by parallel striae, which presumably are the casts of slickensided surfaces of the breccia pieces. Plate 9 is a photograph of a typical piece of leached breccia ore. Where the grains of quartz, specularite, and chalcopyrite that impregnate the altered rock were sufficiently abundant to support one another after the rock matrix was removed, the result of leaching is a fine-textured honeycomb of those minerals. Some parts of the honeycomb are made up of fragile unoriented intergrowths that preserve the distribution of the same minerals in the altered rock; other parts contain continuous ribs or walls that preserve the distribution of stringers originally cutting the rock. The honeycombed areas fade, in some specimens, into altered rock, and stringers of quartz, specularite, and chalcopyrite can be traced through rock into and across adjacent honeycombed parts. The quartz of the honeycombs is feathery and without regular structure and lacks the crystal terminations of quartz deposited in open spaces, except where coated with quartz of the next stage of deposition. Plate $10, A$, is a photograph of some of the finetextured honeycomb, and plate 11 shows the character of the altered. rocks from which the honeycombs were derived. Plate $10, B$, is a photograph of intergrown chalcopyrite and sphalerite, which presumably had replaced the wall rock but from which the residual rock has been leached.

The honeycombs in the leached gray, green, and red cherts are similar to the feathery quartz honeycombs described above, though naturally more quartzose. The cavities are entirely distinct from the typical quartz-lined shrinkage druses present elsewhere in the chert. The honeycombs seem to be widely distributed in the veins in the same sense that minerals of any particular stage are widely dis- 
tributed, though much more abundant at some places than at others. It is possible that leaching may have been more prominent than now appears, for the honeycombs may have been crushed beyond recognition at some places during one of the several stages of later movement along the vein; and the honeycomb structure also may have been obliterated at some places by later deposition. The walls of the honeycomb cavities and the thin ribs in them are coated in places with minerals of the third stage of deposition (see pl. 12, $A$ ), a fact that fixes the relative age of the leaching, but elsewhere the walls are uncrusted, and it is reasonable to infer that at still other places the cavities are filled completely. The irregular distribution of leaching and of later minerals in the cavities fits the conclusion, as discussed on page 22, that the solutions of each stage of deposition tended to follow independent paths along the veins.

The leaching solutions differed radically from those of the precedjng stages of mineralization, for they dissolved minerals that had been formed by earlier solutions; presumably they were undersaturated with the constituents of sericite, chlorite, and calcite and made up the deficiency by leaching those minerals from altered rocks along their channelways. The leaching may have been done by independent solutions between the second and third stages of deposition, or it may have been done equally well by the fresh solutions at the beginning of the third stage.

The effects of leaching by hydrothermal solutions have been observed in some epithermal deposits in which early lamellar calcite has been leached from an intergrowth with quartz, to leave behind a boxwork upon the walls of which later minerals were deposited, as in the classic example at De Lamar, Idaho, ${ }^{18}$ but such effects have seldom been reported for deposits of deeper-seated origin. As outlined for the Lordsburg district, the process is similar to that involved in Locke's theory of "mineralization stoping" ${ }^{19}$ except that the rock was leached at an intermediate stage of mineralization instead of at the beginning. In the same degree it is similar to the corrosion of quartzite prior to mineral deposition at the Tucson mine at Leadville ${ }^{20}$ and also at Gilman, Colo. ${ }^{21}$ The process more closely resembles the hydrothermal leaching described by C. S. Ross ${ }^{22}$ for the Gossan Lead in Virginia, where rock matter was leached after deposition of the earliest hydrothermal quartz, which in turn had

\footnotetext{
1s Lindgren, Waldemar, The gold and silver veins of Silver City, De Lamar, and other: mining districts in Idaho: U. S. Geol. Survey 20th Ann. Rept., pt. 3, p. 170, 1900.

${ }^{10}$ Locke, Augustus, Formation of certain ore bodies by mineralization stoping: Finon. Geology, vol. 21, p. 431, 1926.

sommons, S. F., and others, Geology and ore deposits of the Leadville mining district, Colo.: U. S. Geol. Survey Prof. Paper 148, pp 289-291, 1927.

${ }^{21}$ Schmitt, Harrison, personal communication.

$\approx$ Ross, C. S., Origin of the copper deposits of the Ducktown type in the southern Appalachian region: U. S. Geol. Survey Prof. Paper 179, pp. 84-85, 1935.
} 
been preceded by an aplite-pegmatite stage that initiated the mineralization sequence.

\section{THURD STAGE OF MINERALIZATION}

The mineral suite of the third stage is simple and includes only abundant quartz, a very little gold- and silver-bearing chalcopyrite and pyrite, and a trace of chlorite. The quartz is a glittering colorless to white crystalline variety that grows in drusy masses looking much like rock candy and that forms knobby and bristling coatings on nearly all exposed surfaces. At places where the open spaces have been filled and in the core of the knobby masses the quartz is milk white and the crystals are compactly intergrown. Plate $12, B$, shows the characteristic "rock candy" structure of this quartz and the sharp boundary of the quartz against the massive chalcopyrite of the preceding stage. Small crystals and crystalline clusters of chalcopyrite and of pyrite are sparingly distributed through the quartz and characteristically form part of the crystalline lining of the numerous druses.

At a few places the crystals of the cavities are crusted by minute flakes of chlorite, which tend to form grapelike clusters of tiny nodules. The leaching described in detail in the immediately preced. ing pages took place during this general period; the leached material was highly chloritic, and perhaps the vein chlorite is some of this leached material that has been transported and redeposited elsewhere, rather than chlorite derived from a primitive source and retained in solution to this late stage.

\section{FOURTH AND FIFTH STAGES OF MINERALIZATION}

The veins were again reopened after the third stage of mineralization and were partly cemented by pink calcite, which is most common as scalenohedrons (dogtooth spar), as much as 2 or 3 inches long, projecting into cavities, some of which are large enough for a person to enter. The cavities lie along the vein walls, and some of them contain a little calcite-coated rubble on the floor; presumably they are places from which gouge and fine breccia have been leached or flushed out. Clusters of small disks (nail-head spar) lie in some of the openings in the earlier vein filling. A partial analysis by Prof. F. C. M. Smithson, of the New Mexico School of Mines, shows that the pink calcite contains 2.1 percent of $\mathrm{MnCO}_{3}$ and 1.1 percent of $\mathrm{FeCO}_{3}$.

A little chalcopyrite and galena was seen in the calcite at two places in the Virginia area, and larger amounts of these sulphides associated with calcite were seen on the mine dumps at Leitendorf.

The fifth stage of mineralization, which followed a fourth period of reopening, yielded only calcite. This calcite is similar in crystal 
form and occurrence to the pink calcite of the preceding stage but is gray to white. It contains 1.5 percent each of $\mathrm{MnCO}_{3}$ and $\mathrm{FeCO}_{3}$. A few short veins seem to contain only this mineral.

\section{STXTH STAGE OF MINERALIZATION}

The five stages of mineralization described in the preceding pages were all parts of an essentially continuous period of mineralization and structural adjustment. The quartz latite dikes were injected subsequent to this general period, and a sixth stage of mineralizition followed the injection of the dikes. As described on page 16, some of these dikes are strongly sericitized, calcitized, and pyritized, and at one place, between the General Jerry Boyle and Tioga claims, a quartz latite dike is cut by stringers of quartz, calcite, and fuorite.

Fluorite has been recognized at only four places in the district and nowhere appears to have been accompanied by any minerals of commercial importance.

\section{OXIDATION AND ENRICHMENT}

Supergene modification of the ores offers few features that need detailed consideration. The depths penetrated and the paths traversed by the oxidizing and enriching solutions are erratic, even in a single vein, as might be expected from the combination of mountainous topography, erratically open character of the hypogene vein filling, and post-ore faulting. Enriched ores have been mined as deep as 1,500 feet below the outcrop (about 1,200 to 1,400 feet below the normal water level), and vein matter completely leached of ore minerals lies at least 1,600 feet below the outcrop. On the other hand, sphalerite, the most easily oxidized of the hypogene minerals of the district, lies within a few feet of the surface in some veins. Plate 13 (oversheet) shows the erratic distribution of the different features of supergene alteration along the Emerald vein. The stopes marked "enriched copper ore" contained ore enriched to a copper content higher than that in the average hypogene ore; those marked "enriched silver ore" contained more silver than would be indicated by the silver-copper ratio of the hypogene ore; and those marked "enriched gold ore" contained more gold than would be indicaterl by the silver-gold-copper ratios of the hypogene ore. Youtz ${ }^{23}$ says that stopes averaging 0.5 to 0.75 ounce of gold to the ton of ore were mined directly under others averaging 0.08 to 0.10 ounce to the ton.

The supergene minerals include the common oxidation and secondary sulphide minerals of copper, lead, zinc, gold, and silver in proportions similar to those of their hypogene counterparts; for

${ }^{23}$ Youtz, R. B., Mining methods at the Eighty-five mine, Calumet \& Arizona Mining Co., Valedon, N. Mex. : U. S. Bur. Mines Inf. Circ. 6413, p. 4, 1931. 
example, secondary copper minerals are common and occur in commercial amounts, whereas secondary minerals of lead and zinc are sparse. A little secondary calcite is present, as well as a few plates of wulfenite and crusts and stains of cuprodescloizite, a lead-copperzinc vanadate. The wulfenite and cuprodescloizite seem to be confined to those parts of the veins that have basalt walls. As would be expected from the absence of limestone country rock and from the comparative paucity of calcite in the veins, carbonate minerals are not abundant.

Although large bodies of ore rich in chalcocite and covellite were mined, the net copper content of the average supergene ore mined was only about 0.3 percent higher than that of the average hypogene ore, enrichment at one place being largely balanced by leaching at another. Many stopes were mined because of a high gold content, but as with copper, the net enrichment in the average supergene ore as mined was slight, amounting only to 0.02 or 0.03 ounce to the ton. On the other hand, enrichment almost trebled the average silver content of the ore, increasing it by 2 ounces or more to the ton. It was the general high silver content and the local high gold content of the supergene ores that led to the mining of leached material low in copper.

\section{FUTURE OPERATIONS IN THE LORDSBURG DISTRICT}

Activities in the Lordsburg district have depended, almost since their beginning, less upon the metallic content of the ore, as in most other districts, than upon an unusual demand for siliceous fluxing material at a nearby copper smelter, and future operations promise to be controlled by similar outside influences. The gross value of the metals in the ore has been hardly large enough to cover mining and smelting charges, and now that the demand for fluxing ore of this nature has ended, further production from the Lordsburg district may be discouragingly small for a long time to come.

Most of the ore mined in the district was used by the Calumet \& Arizona Mining Co. at its smelter at Douglas, Ariz., and in 1920 that company found it advisable to insure the source of supply by purchasing the Eighty-five mine. This mine, which produced over nine-tenths of the ore mined in the district, was shut down when the Calumet \& Arizona smelter was taken over by the Phelps Dodge Corporation, simply because that corporation could obtain fluxing ore more cheaply elsewhere. As a mining venture, strictly divorced from its smelter affiliations, it was not considered attractive.

The Lordsburg district may contain many undiscovered ore shoots, but the ore is likely to be of essentially the same average grade as that mined in the past, and therefore there would seem to be little 


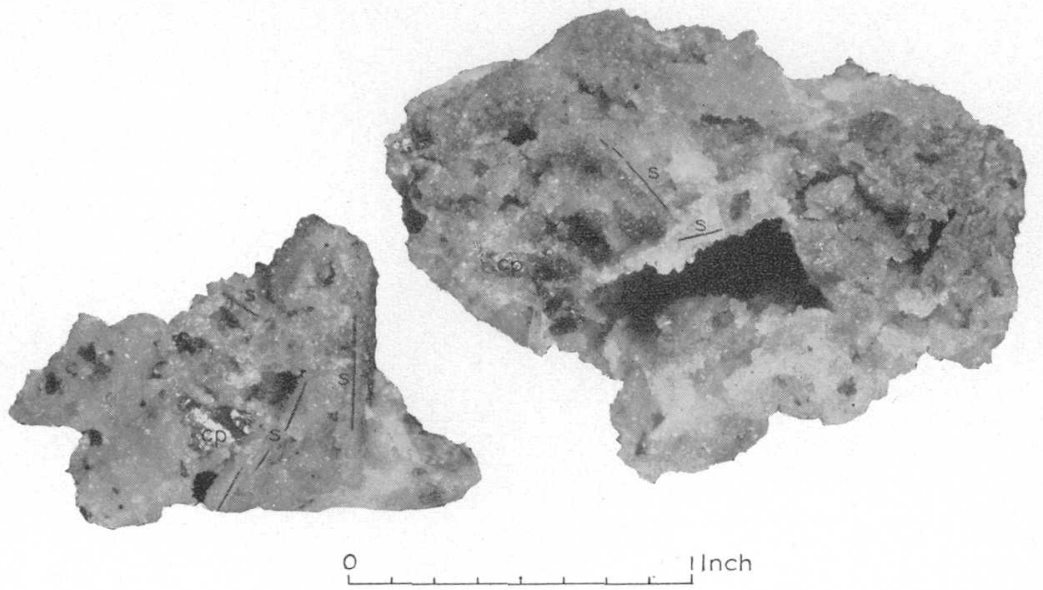

A. HONEYCOMBED ORE COATED WITH QUARTZ AND CHALCOPYRITE (cp) OF THE THIRD STAGE OF DEPOSITION.

The narrow lines (s), which were strengthened slightly on the photograph in order to stand reproduction, are the quartz-specularite ribs of the original honeycomb.

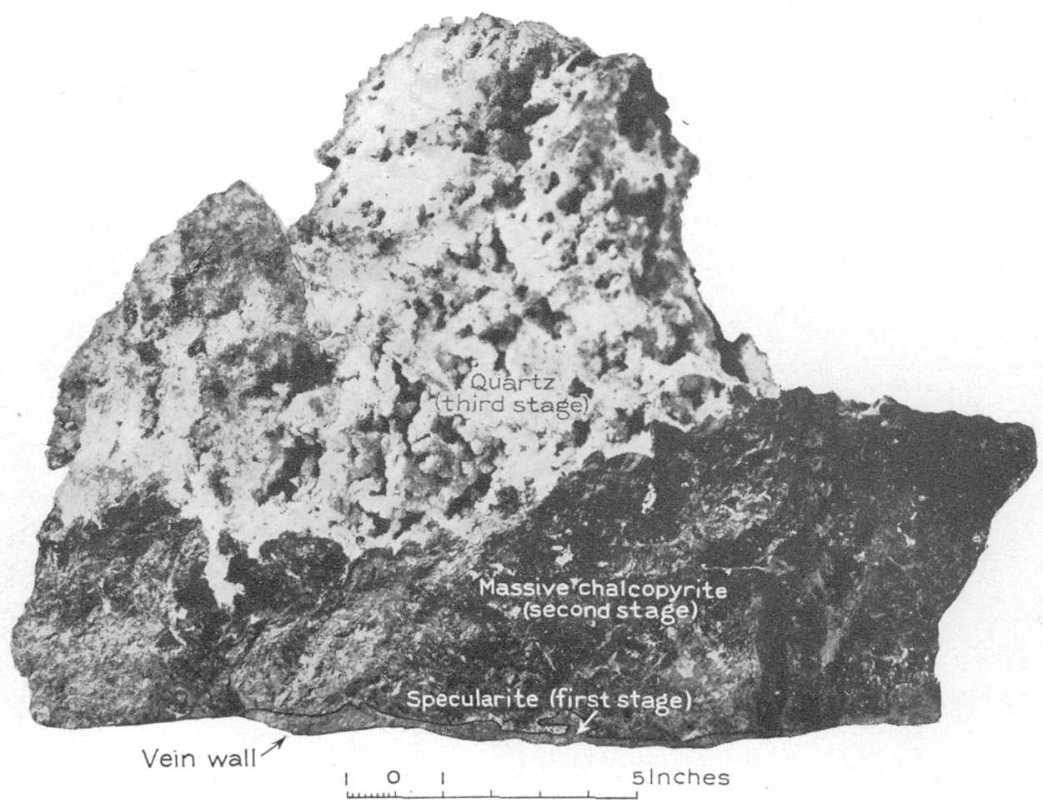

B. SPECIMEN OF ORE FROM THE EIGHTY-FIVE MINE, SHOWING FIRST THREE STAGES OF MINERALIZATION AND THE TYPICAL DRUSY, "ROCK-CANDY" APPEARANCE OF THE THIRD-STAGE QUARTZ.

The black spots in the quartz are drusy cavities. 


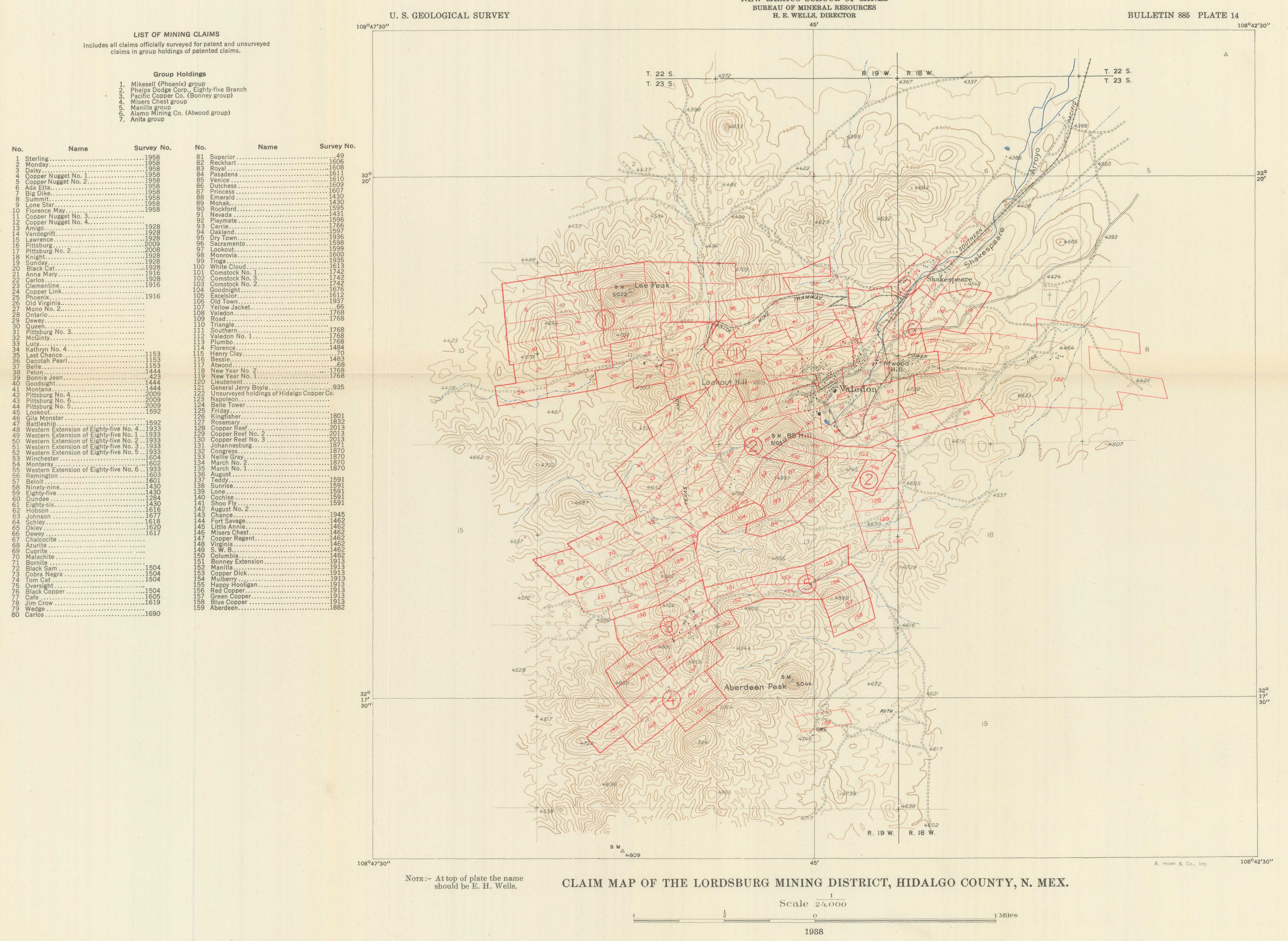


incentive to look for it. Indeed, when the large-scale operations were abandoned in 1932, the known reserves of the district amounted to as much as 150,000 tons of ore, some of which is of comparatively high grade. The ore already mined may be divided roughly into two classes-low-grade hypogene ore, which was mined on a large scale, and moderately enriched ore, which was mined at the smaller properties. The average gross value of the metals in the hypogent ore, not including any lead and zine, which are not paid for, has been about $\$ 11.50$ a ton; that for the enriched ore has been about $\$ 14$ a ton. Production costs at the Eighty-five mine, under the advantages of systematic operations on a large scale-7,200 tons $\Omega$ month-and of a special arrangement with a smelter owned by the same company, averaged $\$ 7.80$ a ton, including transportation and smelting charges. ${ }^{24}$ For the smaller mines, the total cost was probably about $\$ 11.50$ or more a ton. The difference between these costs and the average gross value of the ores hardly suffices to cover the customary smelter deductions on metal content and on metal quotations, the greater value of the ore mined at the smaller mines being offset by higher unit costs of mining and transportation and by greater smelter deductions. Consequently, the copper ore of the district can hardly be mined at a profit under average metal prices unless it can command a special premium at the smelter.

These statements hold as well for operations under the high prices prevailing since 1933 for gold and silver as for past operations at the old prices. The average price of copper during the active life of the district was more than 15 cents a pound,,$^{25}$ and at any price for copper less than about 12 cents a pound the gross value of the ore is less.under the new prices for gold and silver than under the old prices. A profit could be made under the prices for all metals in 1934, however, by lessees who could mine ore higher in grade than the average and at less than average costs. Should prices for gold and silver increase and the price of copper rise materially above 12 cents a pound, without substantial increase in costs, the need for a smelter premium might disappear, but there is little likelihood of large-scale operations unless a continuance of the increased prices can be assured or unless, either by extremely efficient mining or by efficient concentration of the ore before shipment, a higher differential than existed in the past can be established between cost of operations and smelter returns. Operations, perhaps on a moderately large scale, could be resumed with a renewed demand for fluxing ore by the custom smelter at El Paso, Tex., when conditions in the copper

« Youtz, R. B., op. cit., p. 25.

${ }^{25}$ Computed from Am. Bur. Metal Statisties Yearbook, 1933, p. 110, 1934. 
industry improve, and it is conceivable that under some conditions the miner may receive a greater profit from a smelter premium for his ore than he could from concentrating the ore before shipment.

\section{THE MINES}

\section{EIGHTY-FIVE MINE}

\section{GENERAL FEATURES}

In point of production, history, and character of ore deposits, the Eighty-five mine practically constitutes the Lordsburg district. All claims in the district that have been officially surveyed for patent and unsurveyed claims in group holdings of patented claims are shown on the claim map (pl. 14), which is taken largely from a map compiled by D. F. Underwood, engineer at the Eighty-five mine. The following paragraphs deal chiefly with features not already described.

The Eighty-five mine is on the Emerald vein and lies beneath Eighty-five Hill. The shops, mine offices, and main entrance to the mine are in Valedon, at the foot of the northeastern slope. (See pl. 2.) The mine workings, which have explored the vein to a vertical depth of 2,250 feet and for 4,350 feet along the strike, consist of two deep vertical shafts-the Emerald and the Jim Crowand 16 levels, as shown in plate 13. Level workings consist primarily of drifts along the vein, though a few crosscuts were driven into the walls for diamond-drill stations and to explore parallel veins. A crosscut at the west end of the 450 -foot level investigates the veins on the Carlos claim, and two crosscuts at the east end of the 650-foot level were driven to investigate the downward continuation of the Nevada and Old Eighty-five veins.

The main entrance to the mine is through the haulage adit on the Zero level, which connects with the Emerald shaft (the main operating shaft) at 865 feet from the portal. The Jim Crow shaft, sunk in 1930 in order to explore the west end of the mine, serves for ventilation and as an emergency exit. The upper workings of the mine are tapped also by the Upper Dundee, Lower Dundee, and Superior shafts, which were the operating shafts before the property was taken over by the Eighty-five Mining Co.

Temperatures within the mine increase at an average rate of about $1.4^{\circ}$ C. $\left(2.6^{\circ}\right.$ F.) per 100 feet of depth. Temperatures at working faces in the lower levels commonly range above $90^{\circ} \mathrm{F}$.; and the relative humidity on those levels is 100 percent. The following table ${ }^{26}$ shows the temperature and humidity at different places in the mine.

\footnotetext{
${ }^{26}$ Youtz, R. B., Mining methods at the Eighty-five mine, Calumet \& Arizona Mining Co., Valedon, N. Mex.: U. S. Bur. Mines Inf. Circ. 6413, p. 21, 1931.
} 
Temperature and humidity in the Eighty-five mine

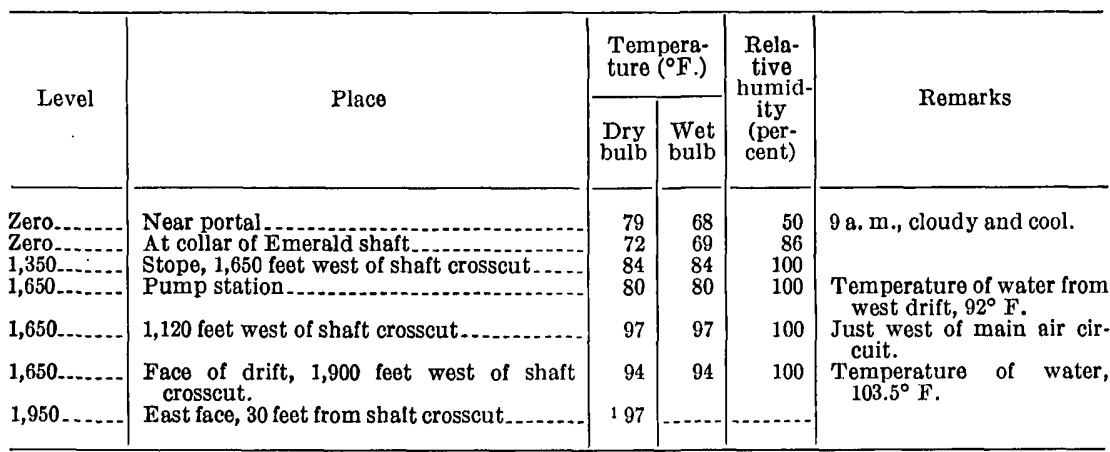

1 Observation by S. G. Lasky.

\section{GEOLOGIC RELATIONS}

The general relations at the Eighty-five mine are comparatively simple. (See pls. 5, 3, 15, and 16). The vein, which is in a fault fissure of small displacement (see p. 22), cuts at nearly right angles across the northern horn of the granodiorite stock. At the southern edge of the horn, at the Superior shaft, it passes through a narrow, elongate pendant of basalt, embraced by two arms of granodiorite and extending to the lowest levels of the mine. In the western part of the mine the vein strikes at an average of $\mathrm{N} .33^{\circ} \mathrm{E}$. and dips at an average of $80^{\circ} \mathrm{SE}$., but a short distance west of the Emerald shaft it begins to curve eastward, and in the eastern part of the mine it strikes N. $65^{\circ}$ $\mathrm{E}$., the change in strike being accompanied by a steepening in dip.

The results of post-ore movement along the vein are prominent, as described on page 30. Two transverse post-ore faults belonging to the northward-trending system of the district cut the vein in the eastern part of the mine, but the offset of the vein is insignificant.

\section{ORE DEPOSITS}

The size and shape of the ore shoots in the Eighty-five mine are shown in plate 13 . The ore limit in these shoots was placed at a copper content of 2 percent, but lower-grade ore was mined where operating factors indicated the desirability of doing so. The economic limit of mining in the smaller mines of the district seems to have been a copper content between 3.5 and 4 percent, and that part of the Emerald vein containing 4 percent or more of copper has been outlined in plate 13 in order to show what the size and shape of the ore shoots would have been had it been necessary to adopt the same limit at the Eighty-five mine. This high-grade shoot shows the same flat-lying outline as the mineralized shoots of other stages of deposition. (See pl. 13, oversheet.) Doubtless other shoots 
of high-grade ore existed in the upper part of the mine, but records are lacking.

As shown in plate 13, the ore shoots include chiefly a broad band pitching southwestward and bordered by a narrower parallel band to the east. The barren stretch between the two bands lies within and pitches diagonally across the broad, shallow trough in the vein produced by the changes of strike and dip described above and as indicated on plate 15. The pitch of the two bands and the intervening barren stretch is approximately parallel to the western wall of the stock. The width of the vein within the shoots ranges from 2 to 22 feet and commonly lies between 5 and 10 feet; the average width is 6 or 7 feet. Bulges more than 10 feet in thickness or depressions less than 5 feet are generally abrupt, as shown in plate 13 , upon which lines showing equal vein widths have been drawn for a part of the mine.

The oversheet for plate 13 shows the part of the vein in which supergene modification of the ores is pronounced and also, as far as possible, where the ore was enriched in copper, silver, and gold, and where it was impoverished by leaching of the valuable metals. The writer has calculated, from detailed assay and production records supplemented by underground observations, that about one-third of the ore mined was either totally or to a marked degree modified by supergene solutions and that the average grade of this supergene ore was about 3 percent of copper and 3.5 ounces of silver and 0.14 ounce of gold to the ton.

\section{CONTINUATION OF ORE BEYOND KNOWN LIMITS}

The outlines of the known ore limits, as shown on the longitudinal projection of the mine (pl. 13), give the impression that the ore shoot splits into a number of roots and that it has been practically bottomed. This impression is heightened by a statistical study of the length of stoping ground on the different levels. Figure 9 shows the results of this study graphically. It will be noted that the aggregate length of stoping ground has been fairly constant from the zero to the 1,500-foot level, decreasing abruptly above and below those limits. Branches of the shoot crop out on the surface above the zero level, and therefore the full stoping length at different altitudes above that level may not be shown in the stoping-length diagram, but to judge from plate 13 , and from the similarity of shape at the top and bottom of figure 9, not much of the ore shoot has been eroded, the present surface barely truncating the topmost branches.

It seems reasonable to assume that other ore shoots lie at unexwlored depths and that the roots of the known shoots connect along inore or less devious paths with the top branches of an underlying ore body. No prediction can be made, however, as to the depth at 
which such a body may lie. The ore showing on the 1,800- and 1,950foot levels may be part of a large underlying shoot, or it may be part only of a small outlying pod.

More than nine-tenths of the ore extracted from the Eighty-five mine had granodiorite on one or both walls. The vein continues beyond the limits of the granodiorite, but as thus far explored it tends to be narrower and more stringerlike in the basalt than in the granodiorite. These facts suggest that the granodiorite was the more favorable for ore deposition, either because of a chemical

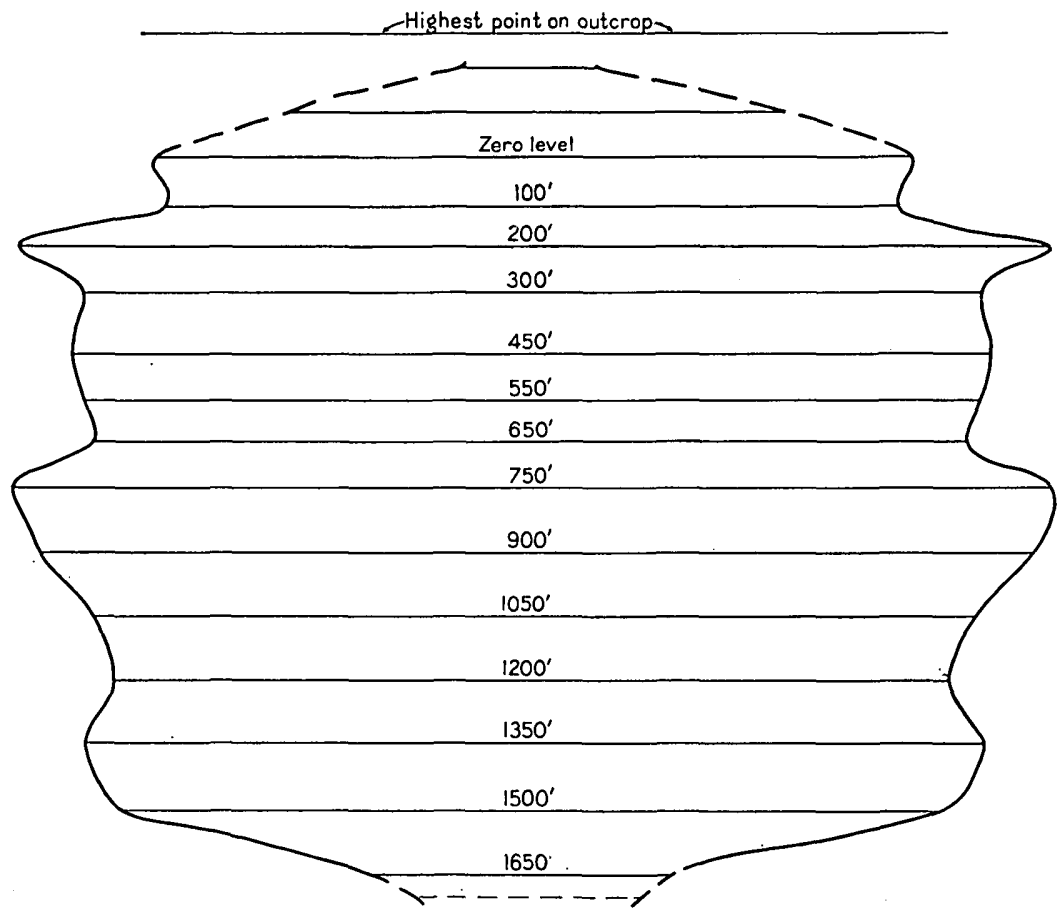

Figune 9.-Variations in aggregate length of stoping ore on the different levels of the Eighty-five mine to the 1,650-foot level. Drawn to scale.

control or because it fissured more readily. Nothing was noted in the ore shoots, however, that indicated a chemical preference for the granodiorite, and the suggestion that the granodiorite may have fissured more readily than the basalt is belied by the behavior of individual fracture zones, some of which change sharply from strong crushed or fissured zones in basalt to tight joints in the granodiorite.

Furthermore, not enough work has been done, either in the Eighty. five mine or elsewhere in the district, to prove whether or not tho less distinct nature of the vein in the basalt is a general feature. If it is true, however, that the granodiorite, for whatever reason, was much more favorable for ore deposition than the basalt, then the 
territory to the southwest on the lower levels of the Eighty-five mine should be favorable ground. The vein seems to be following the trend of a partly covered intrusive ridge of granodiorite extending between the northern horn of the stock and the main mass (see pl. 5), and continuations to the southwest of all levels below the 1,500-foot level are likely to be largely if not altogether in granodiorite. Typical mineralization at places along the outcrop of the vein in that direction indicates the possibility of shoots wherever controlling conditions, probably structural, were favorable.

\section{BONNEY MINE}

\section{LOCATION}

The Bonney mine, the second largest producer in the Lordsburg district, is three-fourths of a mile south-southwest of the Jim Crow shaft of the Eighty-five mine. The holdings consist of 131 acres included within eight claims, as shown on the claim map (pl. 14). The property is reached by good roads from Lordsburg and Valedon.

At the time of the writer's visits the bottom (seventh). level was under water, and an appreciable part of the rest of the mine also was inaccessible.

\section{HISTORY AND PRODUCTION}

The Bonney vein was discovered in 1881 or 1882 and was first prospected for gold and silver. The present group of claims was located at intervals between 1889 and 1902, though under names different from those now in use, and was taken over by the present owner (1934), J. B. Foster, of Lordsburg, in 1905 . Only a little high-grade ore had been shipped up to that time, and shaft 1 , near the northeast end of the outcrop, was the only underground working. In the following year shaft 2 was started 380 feet to the southwest, and during the year several cars of ore, said to have netted $\$ 16$ to $\$ 22$ a ton, were shipped. Operations thereafter were desultory, and by 1912 the two shafts had each reached a depth of only 265 feet.

In the interval from 1905 to 1914 net smelter returns on production are said to have amounted to about $\$ 19,000$, about half of the ore having been derived from development work. Shaft 3, 400 feet southwest of shaft 2, was started in 1915 and was put down to a depth of 390 feet. In 1916 the property was optioned by the Lawrence (San Toy) Mining Co., which produced ore yielding net smelter returns of $\$ 288,000$ from ground above the fifth level during 18 months of unprofitable operation. "Finlay ${ }^{27}$ states that operations during 1916 and 1918 showed a net loss of $\$ 57,000$; profit or loss for 1917 , is stated

\footnotetext{
${ }^{2 t}$ Finlay, J. R., Report of appraisal of mining properties of New Mexico, p. 61, New México State Tax Cómmission, 1922.
} 
as not known. The option was dropped in 1918, and the property was held on lease by several people at intervals during the next 10 years, during which the production had a net smelter value of $\$ 263,000$. In December 1928 the property was taken over by the Pacific Copper Co., which deepened shaft 2 and opened up the seventh level. This company mined 33,712 tons of ore, having a net smelter value of $\$ 253,867$, before relinquishing its option in September 1930 . In 1931 the mine was under lease to Reynolds \& Gwartney, of Lordsburg, who during the year shipped ore for which they received about $\$ 38 ; 000$.

According to the figures furnished by Mr. Foster, the aggregate net smelter value of all ore produced from the Bonney mine through 1931 was about $\$ 890,000$, estimated to be equivalent to about 110,000 tons of ore containing about 6,750,000 pounds of copper, 300,000 ounces of silver, and 10,000 ounces of gold.

\section{MINE WORKINGS}

The Bonney mine is developed by four shafts on the vein, as shown in the plan and longitudinal projection of the mine (pl. 17). To November 16,1931, these shafts had tributary to them 8,900 feet of workings distributed on six levels. Only 525 feet of this total consisted of exploratory crosscuts into the walls, the rest being in drifts along the vein.

It is estimated by the writer that between 13 and 14 tons of ore has been mined or developed for each foot of exploration and development. In view of the narrow width of the vein, this ratio is high and reflects the absence of exploratory workings.

\section{GEOLOGY AND ORE DEPOSITS}

The Bonney vein is in the lower basalt a little more than 1,000 feet east of the granodiorite stock and roughly parallel to the contact. A dike of dark granodiorite porphyry crops out on the surface in the footwall of the vein and cuts erratically across the vein in some of the workings. (See pls. 18 and 19.) A small mass of breccia crops out on the hill adjacent to shaft 2, but none of this rock was seen underground.

The average strike of the Bonney vein is N. $50^{\circ}$ E., and the dip ranges from an average of $70^{\circ} \mathrm{NW}$. in the upper part of the mine to about vertical in the lower part. The vein, which is made up of overlapping segments, is traceable on the surface for 2,600 feet and has been explored underground for a horizontal distance of 1,750 feet. One of the characteristic overlaps shows on the surface at shaft 3 , the stopes opened from shafts 3 and 4 being on different segments. A second overlap is nicely exposed on the sixth level just northeast of 
shaft 2 (see fig. 6 and section C-D, pli. 18) and shows up less well on the fifth level, where the overlap becomes more of a bend. A geologic plan of the fifth level, which is typical of the rest of the mine, is shown in plate 19.

The vein filling contains products of all stages of mineralization except the fluorite stage. It is similar to that at the Eighty-five mine, though it may have a little more sphalerite and galena and may show the hydrothermal leaching a little more strongly. Very little of the ore is absolutely unaltered. The last 36,000 tons mined, which came from the lower levels, contained an average of 3.3 percent of copper and 3.08 ounces of silver and 0.097 ounce of gold to the ton. This is very close to the computed average grade of altered and partly altered ore mined from the Emerald vein. (See p. 46.) The average grade of the known ore in place, as computed by the writer from assays given in private reports made available by the owner, is copper, 4.1 percent; silver, 3.6 ounces to the ton; gold, 0.114 ounce to the ton. Experience at the Eighty-five mine showed that assays had to be reduced 20 percent to take care of unavoidable dilution of ore during mining, and if the assays for the ore in place at the Bonney mine are reduced that amount they become almost identical with those of the average ore mined there. Small shipments have been made that were several times as rich as the average grade.

Plate 17 shows the distribution of the known ore shoots in the Bonney vein. The shoots seem to be very spotty, but this cannot be accepted as a general feature of the vein, because only on the lower levels has the vein been prospected adequately.

\section{FUTURE PROSPECTING}

The segmented nature of the Bonney vein does not seem to have been appreciated fully, for the vein walls have not been prospected thoroughly at the termination of known segments. It appears to have been known that the stopes from shaft 4 are not on the same vein segment as the larger stopes worked from shaft 3 , and crosscuts were driven into the footwall at the south end of the different levels from shaft 3, presumably in search for this other segment. Footwall veins were cut on the fourth and fifth levels, but they were not followed beyond the limits of the known segment to the places where, as shown by experience, the new segment may be expected to widen.

As mentioned above, a typical overlapping of segments is shown on the sixth level just northeast of shaft 2 . The northeast end of the fourth level cuts into the hanging wall, presumably in search for the new segment picked up on the sixth level or for the bend on the fifth. level that corresponds to it, and although three vein stringers were cut they were not explored. The third level follows a stringer 
$4,900 \quad$ SECTION A-A'

$4,900 \quad \begin{aligned} & \text { Through } 1780 \text { raise, } 1780 \text { feet } \\ & \text { southwest of Emerald shaft }\end{aligned}$

SECTION B-B'

Through Superior shaft

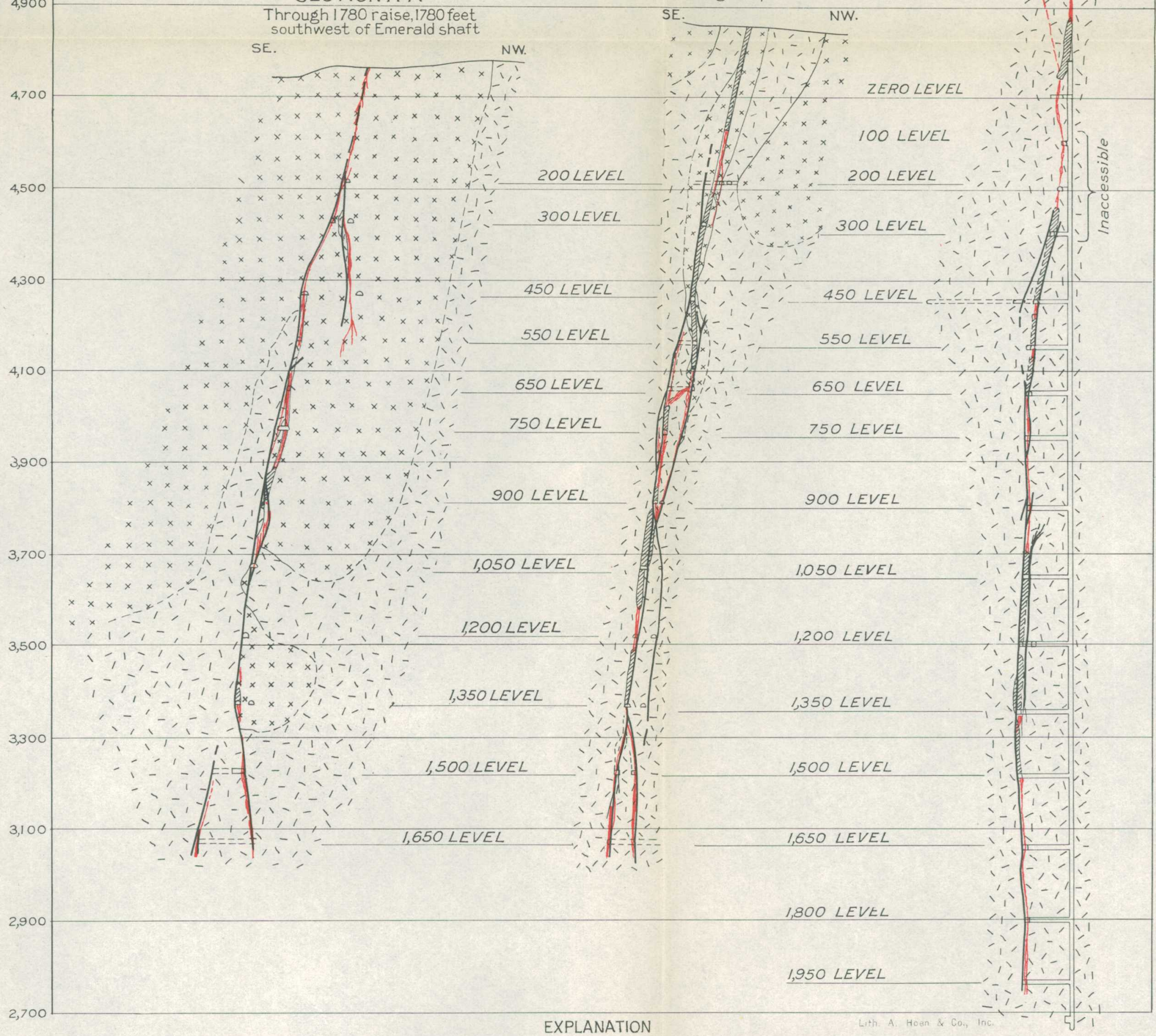

$\left[\begin{array}{rrr}1 & 1 & 1 \\ 1 & -1 & 1 \\ 1 & -1 & 1\end{array}\right]$
Granodiorite
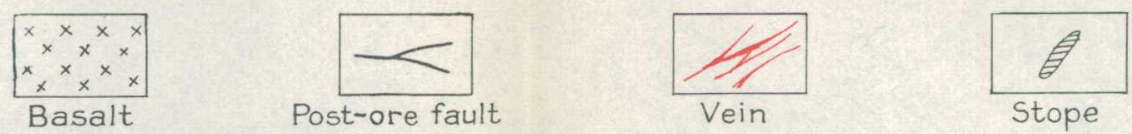

GEOLOGIC SECTIONS THROUGH THE EIGHTY-FIVE MINE 


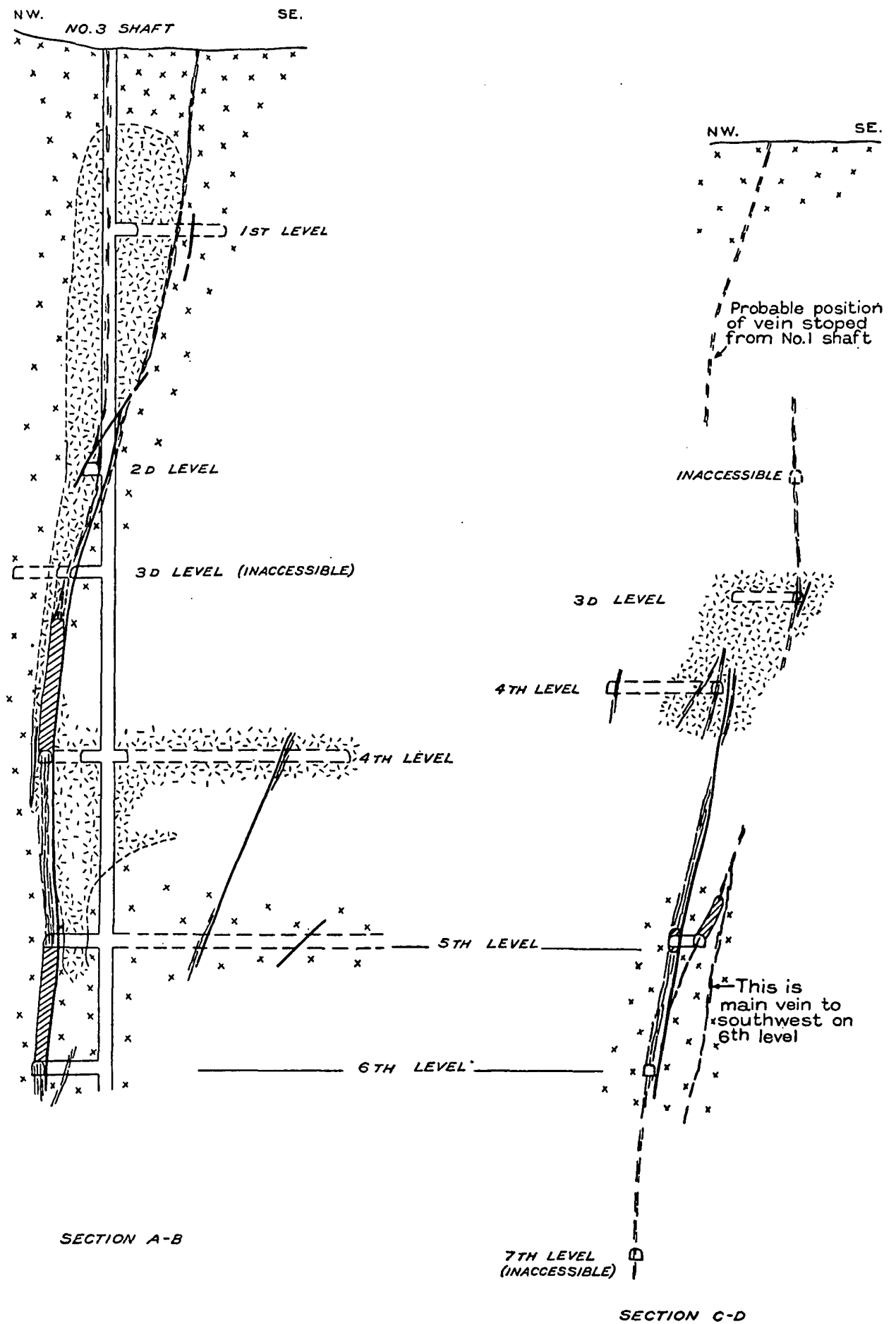

EXPLANATION
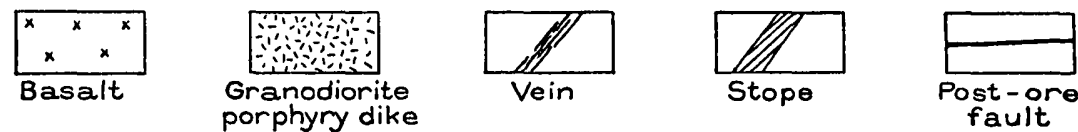

fault 


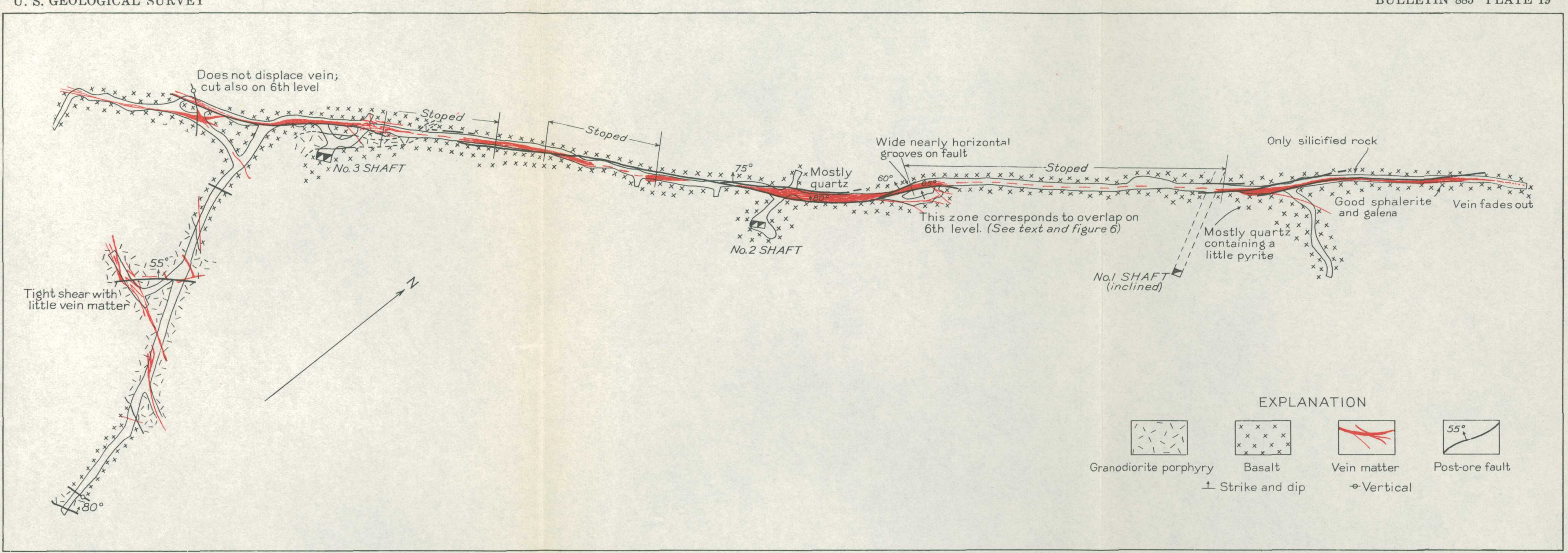

$\stackrel{100}{L} \ldots \ldots+\ldots, 100,300$ Feet

GEOLOGIC PLAN OF THE FIFTH LEVEL OF THE BONNEY MINE 


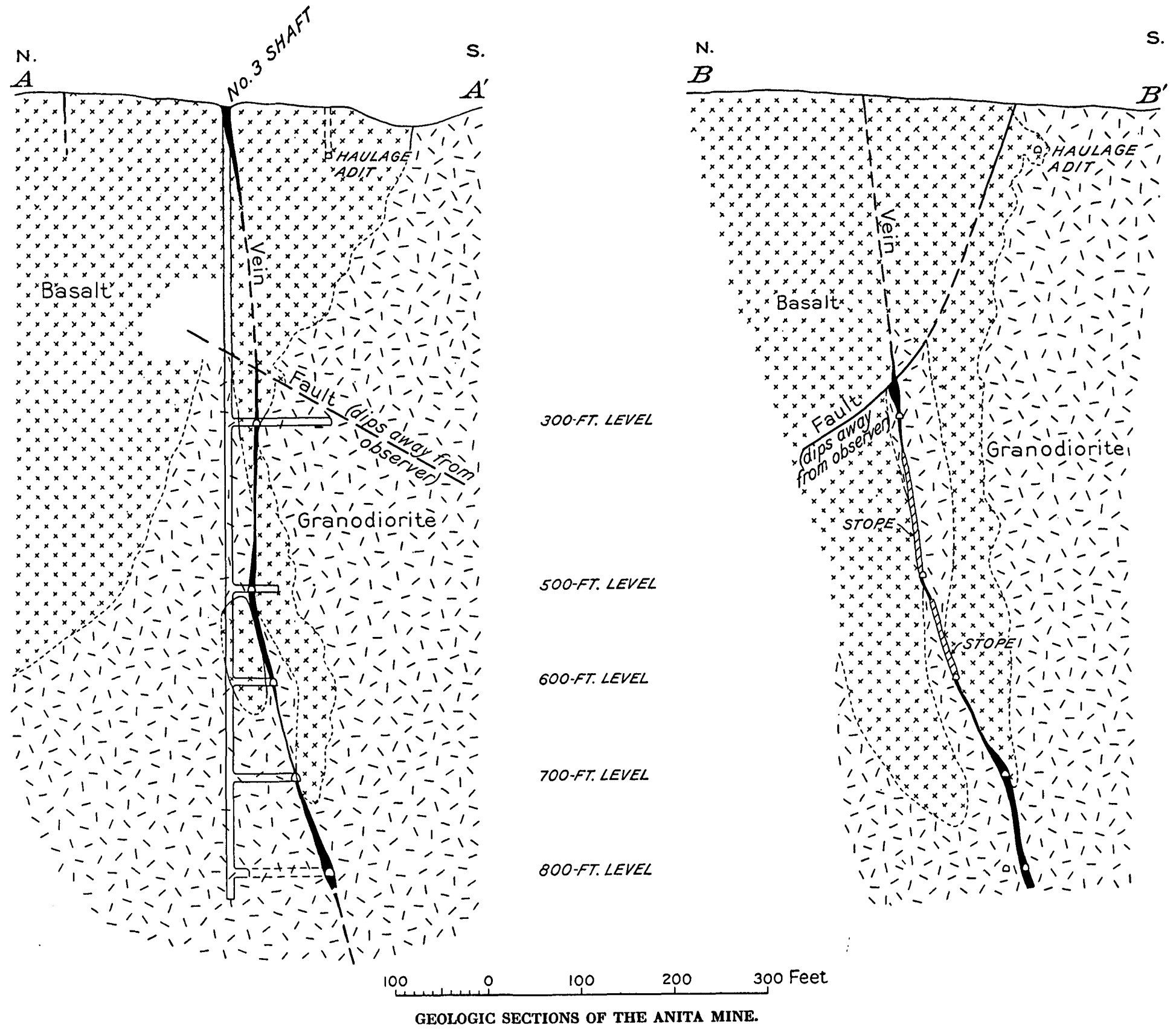


that swings well into the footwall of the main vein at the place where the overlap or bend should be, and this spur vein may be one of the several members of the splitting end of the known segment.

\section{ANITA MINE}

\section{GENERAL FEATURES}

The Anita mine, owned in 1931 by the Wheeling-Lordsburg Mining Co., is at the south foot of Lee Peak, 1 mile west of Shakespeare and Valedon. A good road extends northward from the mine to the paved highway, U. S. 80, that extends west from Lordsburg. The claims that make up the property are shown on plate 14 .

A poor road extends from Shakespeare to the mine and is said to be part of the old Butterfield stage road from St. Louis to San Francisco; presumably, therefore, the prominent outcrop at shaft 6 was one of the first in the district to be examined. Systematic development of the property began in 1927 at shaft 3 and was carried on until the mine was shut down in the fall of 1931, reputedly because of the condition of the metal market. In that interval shaft 3 and the workings from it, as shown in plate 20, were opened and about 10,000 tons of ore was shipped, originating chiefly from development openings. Ore was transported to the railroad siding at Shakespeare over a narrow-gage tramway.

\section{GEOLOGY AND ORE DEPOSITS}

The Anita mine is on one of the southern members of the strong vein zone that lies along the northern horn of the granodiorite stock. (See pls. 3 and 5.) The vein trends eastward at the mine, lying in part along the basalt and granodiorite contact and in part cutting through a nest of outliers in the basalt. It bends sharply to the northeast at shaft 3 and near the eastern limits of the property becomes a diffuse shear zone that is part of the cross linkage of the major vein zone. Farther on this diffuse zone bends eastward again to become the Dacotah Pearl-Bonnie Jean-Goodsight vein.

The vein at the surface in the immediate vicinity of the mine is made up of two linked members, but all mining has been on the south link. The mine workings follow this link closely and by their positions show the variations in dip and strike along it. (See pl. 20.) The sharp bend shown by the outcrop at shaft 3 is exposed on all levels, as it pitches steeply eastward. The vein crops out in basalt in this part of the property, but underground it lies along one wall or the other of a short dikelike prong of granodiorite close to and paralleling the main mass: (See pl. 21.) On the third level, at the shaft crosscut, the vein lies along what is taken to be the edge of the main mass, but to the east it bends sharply northeastward and cuts over to and through the dike, the footwall of which it follows for 
about 50 feet, and thence continues in basalt. West of the shaft the vein skirts the inner (south) wall of the dike as far as shaft 5, where the drift ends. From 125 to 225 feet east of this shaft the vein is made up of two members that may correspond to the two members shown by the outcrop in this vicinity. A few insignificant vein stringers were cut in the crosscut to shaft 6 .

On the 500-foot level, which is altogether east of shaft 3 , the vein lies along the north side of the dike and corresponds closely to the contact. On the 600 -foot level the vein lies within the dike or along its south wall from the west end of the level to a point 240 feet east of the shaft, whence it continues northeastward in basalt until cut off by a cross fault. On the 700 -foot level, a short level east of the shaft, the vein lies along or near the inner side of the dike to the point where the vein bends to the northeast and there cuts through the dike and into the basalt. The 800 -foot level is all in granodiorite below the junction of the dike with the main mass.. A thin hanging-wall spur vein continues eastward beyond the bend of the vein on this level.

The vein seems to average about 5 feet in width, generally occupying the full width of the drifts; but locally it widens to 15 feet or narrows to only a few inches.

There seems to have been little or no displacement along that part of the vein fissure exposed in the mine. Here and there the vein walls are marked by bands of gouge and breccia, but at several places the vein lies along the intrusive contact of the dike without disrupting it. Several transverse post-ore faults, which tend to fade out at shallow depths, cross the vein. (See pl: 20.) One can be traced from the surface, where it shows slickensided surfaces across the vein outcrop, to the 600 -foot level, where it is only a weak shatter zone. It is prominent on the 300-foot level, where it brings a narrow part of the vein opposite a very wide part. (See section C-D, pl. 21.) The direction of movement must have been parallel to the line of intersection of fault and vein, for on no level is any horizontal offset shown. A second transverse fault cuts off the vein at the extreme east end of the 600-foot level. A third transverse fault offsets the vein several feet in the western part of the 600 -foot level, and another jogs the vein a foot or two on the 300 -foot level just east of the shaft.

The vein matter, which is said to contain 70 to 85 percent of silica, consists chiefly of minerals of the second and third stages of mineralization. Only a trace of the first stage, in the form of red quartz, was noted. A moderate amount of last-stage fluorite was seen on the dump at shaft 1 at the east end of the property, but none was seen in place. Sphalerite seems to be fully as abundant as chalcopy; rite, though no assays are available to corroborate this impression. 
Galena seems to be present in about average amounts. Reported assays of ore shipments from the 500- and 600-foot levels range as follows: Copper, 2.45 to 2.7 percent; silver, 9.7 to 11.0 ounces to the ton; gold, 0.07 to 0.09 ounce to the ton. According to a letter from T. B. Henderson, general manager of the company, sampling is said to indicate that ore of minable grade is exposed along 60 percent of the drift openings.

The possible downward extension of the ore shoot represented by the stopes on the 500- and 600-foot levels is indicated in plate 20 . This extension is based solely on the appearance of the vein, for no sample assays were available. Plate 20 shows also the relation of this shoot to the different wall rocks and to the sharp bend in the vein described above. It is possible that this bend had some bearing on the location of the shoot.

\section{ATWOOD (ALAMO) MINE}

\section{GENERAL FEATURES}

The Atwood (Alamo) mine is at the southwest corner of Atwood Hill, just east of Valedon. It is one of the oldest mines of the district and was described by Burchard ${ }^{28}$ in 1881 as one of the four most prominent properties. At that time it was developed to a depth of 115 feet, and several cars of ore yielding as much as $\$ 130$ a ton are said to have been shipped to the smelter at Denver, Colo. The mine was deepened to 220 feet in the following year, but deeper exploration was hindered by water. Detailed records of operations for the succeeding years are lacking, but evidently not much was done. New exploration was started in 1930 by the Alamo Copper Co., which was organized for that purpose. The 500- and 750 -foot levels were opened, but the results were disappointing to the financial backers, and operations were suspended in December 1931.

\section{GEOLOGY AND ORE DEPOSITS}

Plate 22 shows the geology on the different levels of the Atwood mine and a geologic section through the shaft.

The mine explores two closely spaced veins having prominent outcrops. In the vicinity of the mine these veins lie along the south side of the intrusive breccia that forms Atwood Hill, but to the east they cut across the breccia to connect, on the General Jerry Boyle claim, with another prominent vein that roughly follows the north side of the breccia mass. West of the mine the northern and more prominent of the two Atwood veins extends for nearly $11 / 2$ miles to a point due south of the Anita mine; the south vein diverges

es Burchard, H. C., Report of the Director of the Mint for 1881, p. 332, 1882 . 
a little and joins with the Emerald vein at an open stope near the Henry Clay shaft. (See pl. 2.) Several cuts and open stopes mark the position of this part of the south vein.

The mine workings show that the north vein follows, with fair persistency, the northward-dipping and overhanging contact between intrusive breccia and basalt. The south vein, 15 to 150 feet away, lies wholly in the basalt. Both veins are largely silicified rock and are abnormally wide at places. This is particularly true of the north vein, which is at least 30 feet wide on the 150 -foot level. In addition to silicified rock the veins contain the characteristic drusy quartz-sulphide filling of the second and third stages of mineralization. Galena seems more abundant than sphalerite in these veins, which is a reversal of the ustial condition in the district. Tourmaline and specularite of the first stage of mineralization are present here and there, and tourmaline is very prominent where the vein is cut on the 750-foot level. Calcite is present also.

Workings below the supergene zones are not extensive, and therefore very little information is available as to the average grade of the hypogene ore. Plate 22 shows the assay results of nine samples from the 500-foot level, but because of the extreme ranges shown the averages of these assays are not reliable, except possibly for gold content, which is consistent in all assays.

Oxidation seems nearly complete to the 210 -foot level, and local oxidation and sulphide enrichment extend at least to the 500-foot level. All ore stoped has been taken from the oxidized zone. The north vein has been stoped along both walls above the 75-foot level, but so far as known to the writer none of the stopes extend across the full width of the vein. The south vein has been stoped down to the 210-foot level. Much of the ore mined from these stopes is said to have been of excellent grade, particularly in the early days. It is reported that 12,420 tons shipped between 1911 and 1926 contained 0.7 to 7.2 percent of copper and 0.7 to 14.0 ounces of silver and 0.003 to 0.30 ounce of gold to the ton.

\section{HENRY CLAY MINE}

The Henry Clay mine, half a mile west of the Atwood mine and owned by the same company, was located by Benjamin Lake and C. M. Seely on August 15, 1878. It was inaccessible during the writer's visits to the district, and all data on underground conditions were derived solely from private reports on the mine.

The workings consist of a shaft 400 feet deep, 600 feet of drifts on the 400-foot level, about 200 feet of drifts on the 190 -foot level, and an unknown amount on the 100-foot level. A stope 50 feet high extends above the 190-foot level, and another extends from the 
surface down to the 100-foot level. About 2,000 tons of ore was mined from each of the two stopes. The latest work was done in the fall of 1929, when the shaft was deepened and the 400 -foot level explored.

All workings are presumably in basalt, which is the country rock at the surface. The shaft starts down on what seems to be a continuation of the Emerald vein 300 feet northeast of the junction of this vein with the south Atwood vein, though the Emerald vein cannot be traced with assurance from this junction to the shaft. The shaft leaves the vein somewhere below the 190-foot level and on the 400-foot level is 15 feet in the hanging wall. A drift on this level follows the vein 350 feet to the southwest and 250 feet to the northeast, the northeast end stopping at a fault zone that may mark the westward continuation of the north Atwood vein. The vein on this level is partly leached except for 100 feet at the south end. All that is known about the general geology above the 190 -foot level is that the vein is nearly vertical and that it ranges from 3 to $i 0$ feet in width.

\section{MISERS CHEST (LENA) MINE}

The Misers Chest mine, first located by W. G. Boyle on April 17, 1879 , is just over the ridge and half a mile southwest from the Bonney mine. Operations were started in April 1881 and continued steadily until October 1882. By that time an inclined shaft had been sunk on one of the veins to a depth of 115 feet. Some of the development ore was treated at the Shakespeare smelter. A mill was built at Lordsburg in 1902 to handle the ore from this mine, but it ran only a few months. The Misers Chest mine is said to have been the principal mine in the district in 1903, when the shaft was down to the 185-foot level and the mine had more than 1,000 feet of workings. Official records show shipments of ore for 8 of the succeeding 30 years, but no figures are at hand to show the aggregate tomnage or value. The writer estimates from the size of the stopes that about 7,000 tons of ore has been mined.

Plate 23 shows the mine workings as surveyed by the writer in 1931. The mine is near the southwest end of the Eighty-five-Bonney zone of northeastward-trending veins and explores the southernmost member of the zone. The vein, which dips steeply northwestward, can be traced on the surface for 2,000 feet and seems to be made up of a weak and narrow trunk vein from which spurs or branches extend into the walls. The croppings are comparatively vague. The shaft goes down on a hanging-wall spur that is very thin as far as the 50 -foot level but is the chief stoping vein below. The stopes above the 50-foot level are on two parallel footwall stringers that 
mark the trunk vein; both of these have been stoped to the surface in places. The shaft spur joins the trunk vein to the northeast, and on the 350 -foot level the vein is exceptionally wide and contains excellent chalcopyrite ore in the immediate vicinity of. what is probably that junction.

The vein matter consists of quartz, chalcopyrite, subordinate sphalerite, a trace of galena, and the usual oxidation products and is representative of the second stage of mineralization as described on pages $35-37$, though not all the gangue minerals of that stage were observed. The veins crop out in basalt, but dark fine-grained granodiorite (?) shows up on the 50-foot level and entirely encloses the workings on the three lowest. levels.

\section{LEITENDORF CAMP (PYRAMID DISTRICT)}

\section{GENERAL FEATURES}

The Pyramid subdistrict, south of the Lordsburg-Animas highway and 5 miles south of the main part of the Lordsburg district, has always been considered a silver camp, and the general geology and mineralogy as described in published and private reports led to the inference that the veins were of the precious-metals type related to the Tertiary lavas. ${ }^{29}$. It seemed worth while, therefore, to extend the geologic mapping of the Lordsburg district to cover the Pyramid area and to determine the relations of the ore deposits there to the copper deposits in the Virginia area. This additional work disclosed the facts that the veins in the Pyramid district are of the same age as those of the Virginia district and genetically related to them, and that they were originally mineralogically similar, their high silver content being due, certainly in part and perhaps wholly, to supergene enrichment. The chief difference between this enriched ore and equally rich supergene silver ore in the copper veins of the Virginia district is that considerable copper was present in the silver shoots in the Virginia district, whereas copper is in general subordinate at Pyramid.

None of the mines at Pyramid were accessible at the time of the writer's visit, and the mine descriptions given in the following pages were taken from published reports and from maps and private reports made available through the courtesy of the officials of the Eighty-five mine.

\section{HISTORY AND PRODUCTION}

The veins at Leitendorf camp were discovered in 1880, and withm a year this camp had become the most active in the Lordsburg mining

\footnotetext{
${ }^{23}$ Lasky, S. G., and Wooton, T. P., The metal resources of New Mexico and their economic features: New Mexico School of Mines, State Bur. Mines and Mineral Resources; Bull. 7, p. 73, 1933.
} 
area. Four productive: mines-the Venus, Last Chance, Robert E. Lee, and Nellie Bly-were developed, and one or more of these mines has produced ore in nearly every year since the discovery of the veins. The camp appears to have been idle for part of the time from 1885 to 1905 , though records for that period are incomplete, and was idle from 1924 to 1927 and from 1931 to the date of writing (1934).

A large part of the ore mined was shipped directly to smelters, but several attempts were made to concentrate the ores at the mines. A 20-stamp pan-amalgamation mill was erected at the Venus mine (then known as the Viola or Leitendorf) in 1883 and was operated spasmodically with indifferent success until 1893. A small mill was operated from 1894 to 1898 on low-grade copper-silver ore from the Robert E. Lee mine. A flotation plant was operated at the Last Chance mine in 1919 and 1920, and a new 50-ton concentrating plant was built there in 1921 .

The value of the metals produced in the camp up to 1905 has been given as between $\$ 375,000$ and $\$ 450,000$. The production since 1905 has been equally large if not larger, the Last Chance mine alone having produced in 1919 and 1920 concentrates with a.net value of $\$ 93,386$. The value of the total production from the district may be estimated conservatively at about $\$ 1,000,000$.

\section{GEOIOGY AND ORE DEPOSITS}

The veins of the Pyramid area crop out chiefly in basalt at the north edge of the Leitendorf Hills. A patch of intrusive breccia 300 to 400 feet in diameter crops out at the Venus mine, and a quartz latite dike crops out for 1,000 feet or so along the Nellie BlyRobert E. Lee vein. Immediately south of the camp these older rocks are covered by the Tertiary volcanic breccia that forms the Leitendorf Hills. Erosional debris from these hills mantles a part. - of the area, and the location of the veins is indicated chiefly by mine openings from below. The veins trend eastward and northeastward, as in the Virginia area, but none have prominent outcrops.

The material on the dumps indicates that the vein filling is in general similar to that in the Virginia area and is identical with the filling at particular places in that area. It seems to be a composite of material deposited from the second to the fifth stages of mineralization. On the dumps of the Venus and Last Chance mines the vein matter consists chiefly of dense to cherty quartz partly blackened by manganese oxides derived from associated carbonate. Some of the freshest of this material can be recognized as the quartzmanganosiderite mixture common in the western part of the Eightyfive mine. A little barite is present. Fine-grained chalcopyrite and galena and -a trace of sphalerite are distributed in the gangue, and 
small flakes of cerargyrite seem common. Cerargyrite, accompanied by native silver and argentite, is said to have been the most valuable mineral at the Venus and Last Chance mines. Shipments from these two mines consisted of lead-silver-gold ore and silver ore low in copper and lead.

The dumps of the Nellie Bly and Robert E. Lee mines, which seem to be on the same vein, contain considerable calcite associated with quartz and with a fair amount of galena and coarse chalcopyrite, and massive chalcopyrite is said to have been encountered in the vein. Shipments from these mines consisted of lead ore, silver-bearing highgrade copper ore, and low-grade siliceous copper ore containing gold and silver.

\section{VENUS MINE}

Graton's description of the Venus mine ${ }^{30}$ in 1905 is as follows:

The Leitendorf mine, also known as the Viola or Venus, was probably. the largest producer of the district and is reported to have turned out between $\$ 150,000$ and $\$ 200,000$, mostly in silver. *** There are said to have been several parallel veins; the main one, opened at points along the surface, strikes about N. $40^{\circ} \mathrm{E}$. The shaft is about 350 feet deep but in 1905 held much water. A 20-stamp pan-amalgamation mill was operated for over 10 years before the great fall in the price of silver, since which time the property has been idle.

Ore was shipped from the dump of the Venus mine in 1907 and 1922, and underground operations were carried on in 1910 and 1923.

The mine is developed on the 75-, 150-, 225-, and 300-foot levels. The vein is said to range from 3 to 12 feet in width, and the ore along it is pockety. According to A. L. Wells, of Lordsburg, who operated the mine at one time, smelter settlement sheets for some of the ore show an average of 12 ounces of silver and 0.03 ounce of gold to the ton, 0.75 percent of copper, 2.0 percent of lead, and 60 percent of silica.

\section{LAST CHANCE MINE}

Graton's description of the Last Chance mine ${ }^{30}$ in 1905 is as follows :

The Last Chance mine adjoins the Leitendorf on the south. A shaft 180 feet deep was sunk to explore a vein striking a little more to the east than at the Leitendorf and dipping about $60^{\circ} \mathrm{SE}$. The mine was worked from 1882 to 1890 , producing about $\$ 100,000$ in silver. It was then idle for 15 years, but was unwatered in 1905 . The vein was said to be $31 / 2$ to 4 feet wide. The ore had been taken from a shoot pitching to the east. Most of the ore had been mined out down to the 100 -foot level, where the shoot was said to have

\footnotetext{
${ }^{80}$ Graton, I. C., The ore deposits of New Mexico: U. S. Geol. Survey Prof. Paper 68, p.
} 334, 1910. 


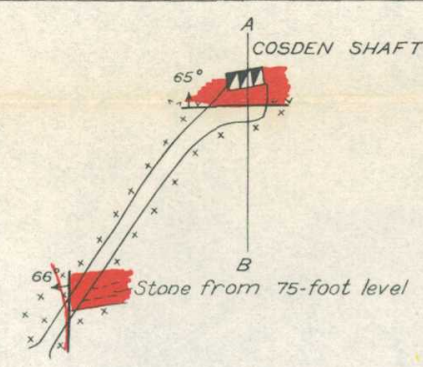

ADIT (35-FOOT) LEVEL

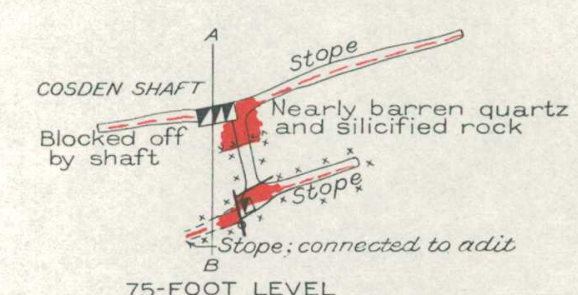
75-FOOT LEVEL
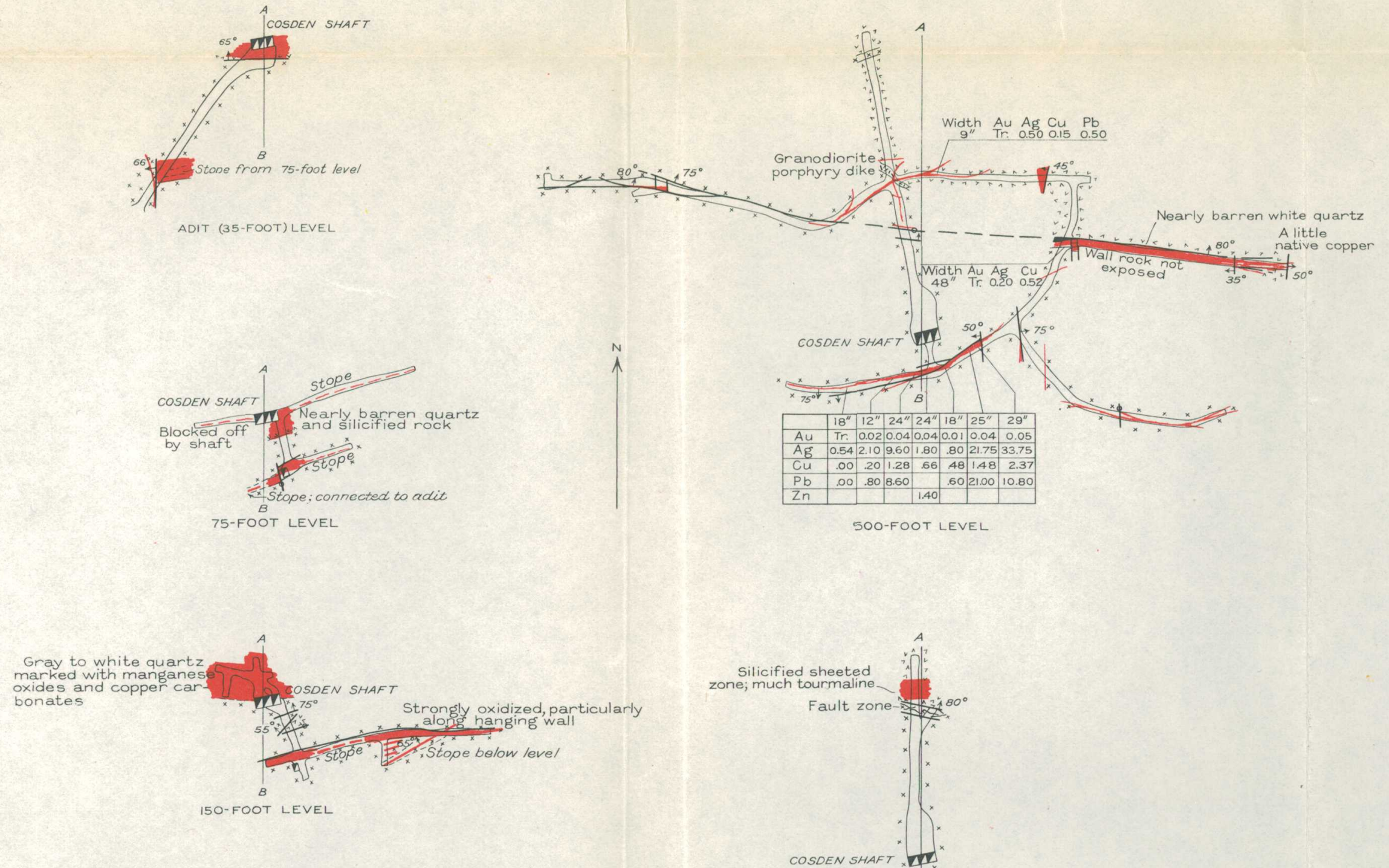

750-FOOT LEVEL
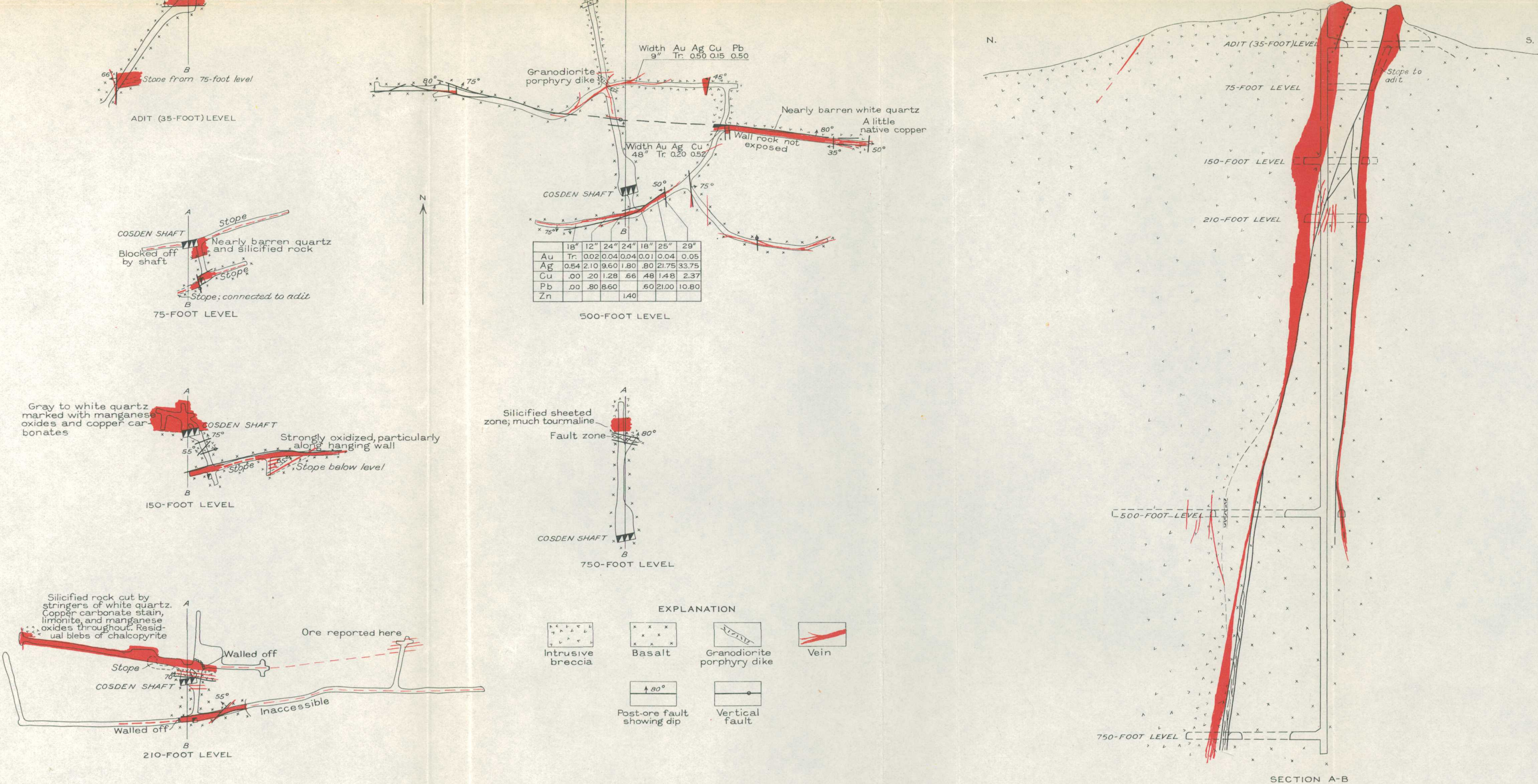


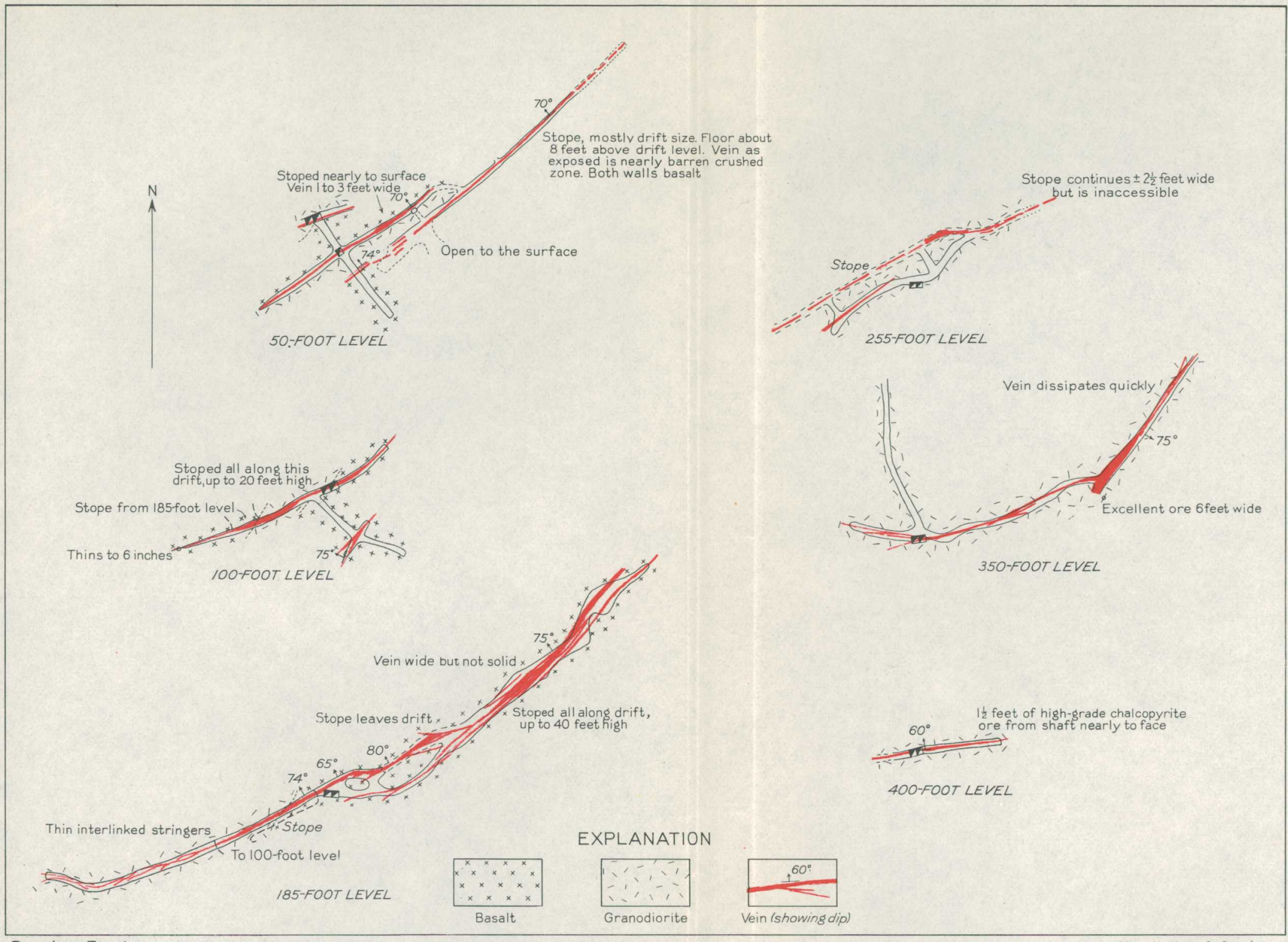

Based on Brunton survey

by S. G. Lasky assisted by E. O. Binyon. 200 Feet

GEOLOGIC LEVEL MAPS OF THE MISERS CHEST MINE 
w.

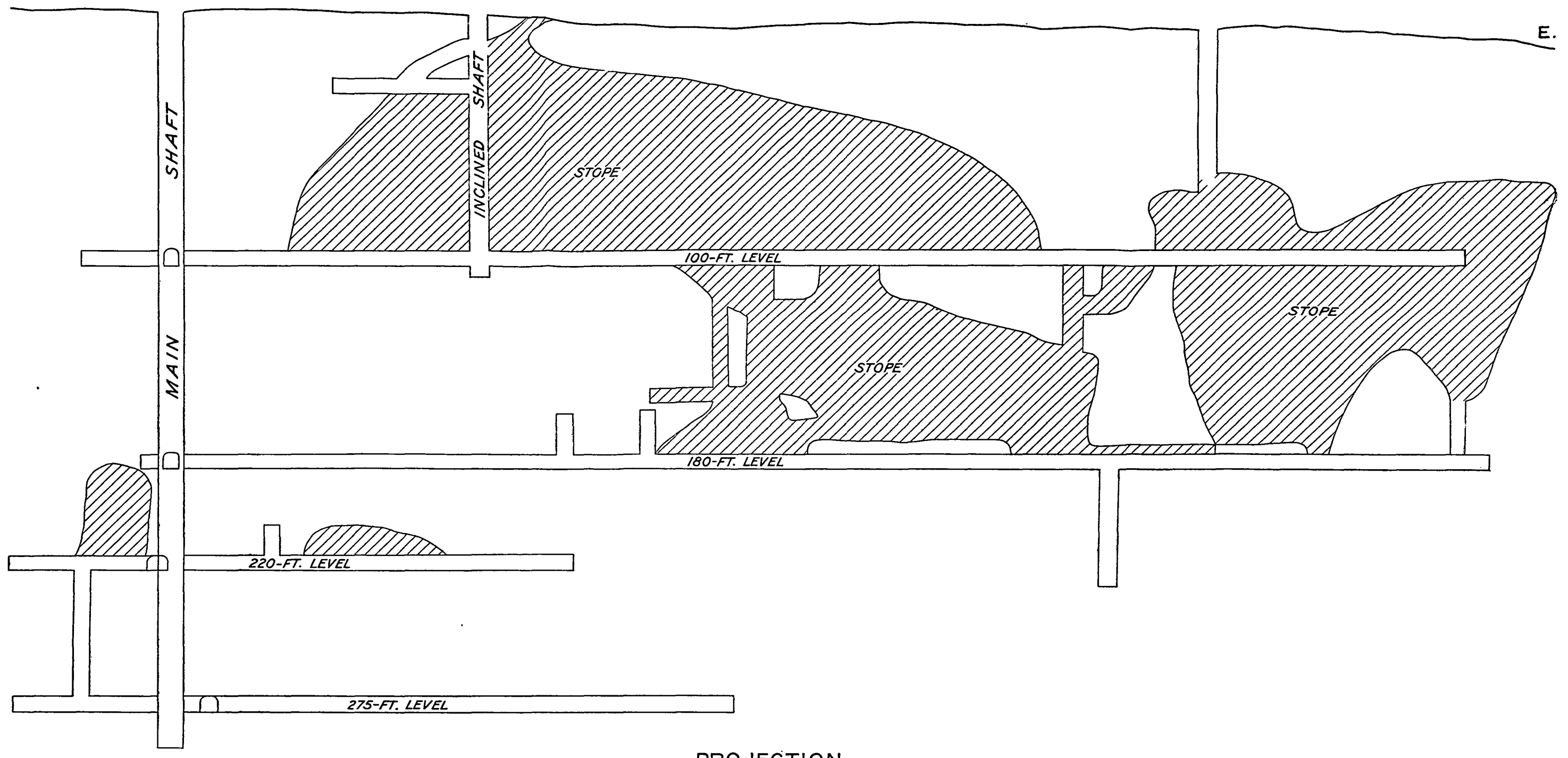

PROJECTION

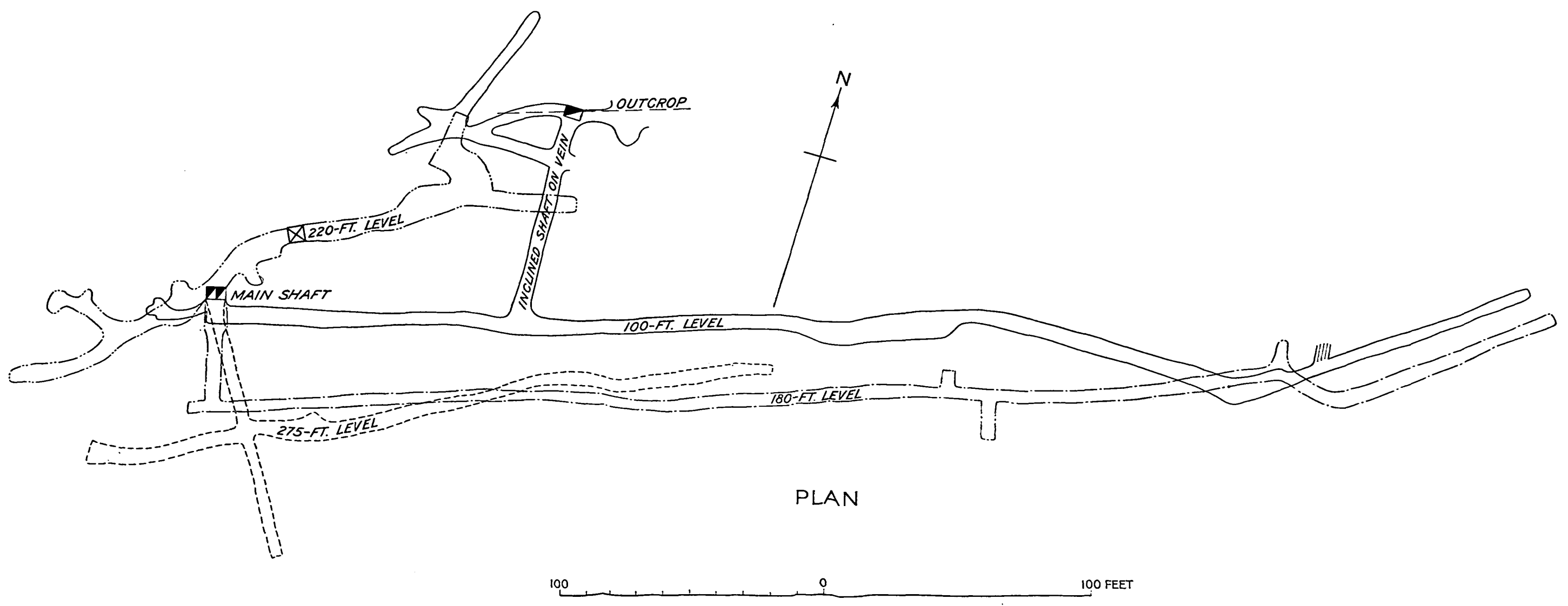

PLAN AND VERTICAL PROJECTION OF THE LAST CHANCE MINE AS DEVELOPED IN 1920 


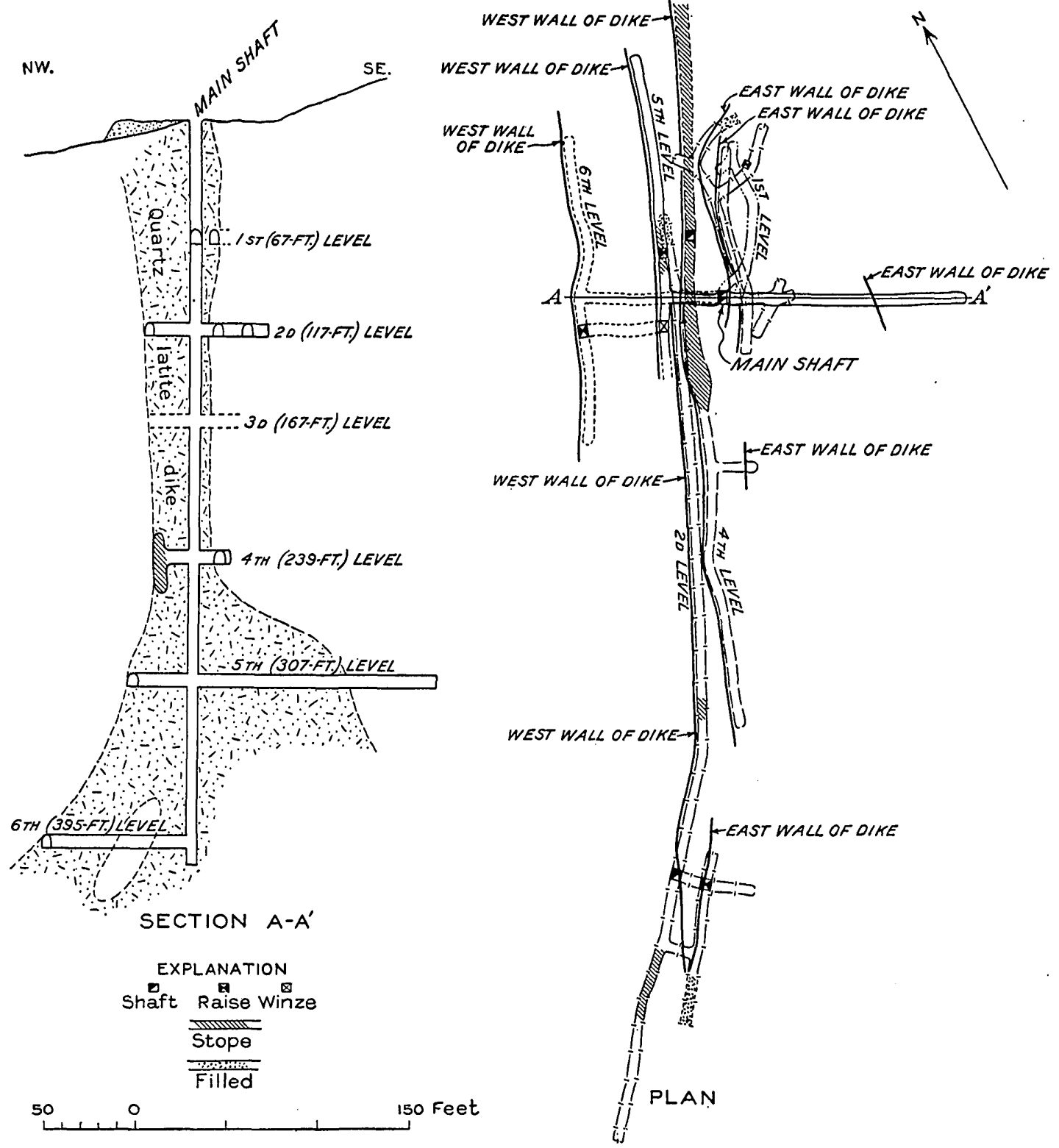

PLAN AND SECTION OF THE NELLIE BLY MINE AS DEVELOPED IN JULY 1908.

Copied from an old map, author unknown. 
a stoping length of 300 feet of shipping grade and still more of concentrating grade. The work in progress at the time of visit was aimed to extract ore from the lower levels that could not be profitably worked in the earlier days.

The mine was operated each year from 1918 to 1923 , and small lots of ore were shipped also in 1929 and 1930. Plate 24 shows the workings as developed in 1920; some additional development work was done on the 275 -foot level in 1921 .

Ore has been mined from two veins, and two other veins have been discovered. The main vein, upon which the mine was originally opened, has been followed from the surface to the 275 -foot level. Near the surface it has an average dip of about $50^{\circ} \mathrm{SE}$., but it begins to steepen just below the 100 -foot level, where it is intersected by the shaft, and is essentially vertical between the 180- and 275-foot levels. A second vein, also dipping about $50^{\circ} \mathrm{SE}$., is cut on the 220-foot level and has two small stopes upon it on that level. Two other veins, both vertical, are exposed on the 275 -foot level, one at the shaft and one 20 feet to the north.

All ore in the main vein east of the shaft has been mined out to the 180-foot level. The vein is well defined at the east face of this level but is only 14 inches wide and of low grade. The average silver content of the ore, which occurred in two irregular shoots, seems to have been about 20 ounces to the ton. Sampling is said to indicate that the filling in the different veins is below commercial grade along the greater part of the mine workings as developed in 1922. Four shoots are said to be exposed on the 275-foot level; these have an aggregate length of 336 feet and an average width of 4 feet and contain an average of 15.5 ounces of silver to the ton, of which 2.5 ounces is in the form of silver chloride, 0.005 ounce of gold to the ton, 0.25 percent of copper, and 61 percent of silica. Two of these four shoots are on the main vein, one is on what is said to be the continuation of the flat-lying vein stoped on the 220-foot level, and the fourth is on the vertical vein north of the shaft.

\section{NELLIE BLY AND ROBERT E. LEE MINES}

Graton's description of the Nellie Bly and Robert E. Lee mines ${ }^{31}$ in 1905 is as follows:

The Nellie Bly and Robert E. Lee mines, lying north of the Leitendorf and Last Chance, are owned by the Pyramid Peak Consolidated Mining Co. They are located on a vein that strikes northeastward and dips to the southeast, the Nellie Bly being southwest of the Lee. In a chloritized zone of rock * * * are found reins of quartz and calcite carrying chalcopyrite and bornite. The Nellie Bly mine is developed by a vertical shaft 130 feet deep. At water level, 70 feet, one ore shoot was found 50 feet long and nearly 5 feet wide; it

s1 Graton, L. C., op. cit., p. 334 . 
carried chiefly chalcopyrite. On the same level a smaller mass of rich bornite ore was said to have been found. ${ }^{32}$. Chalcopyrite ore with $\$ 2$ in gold to the ton was also found in two shoots on the lower or 118-foot level. It was stated that similar ore had been found in the Windmill shaft, 350 feet farther. southwest. The production of the Nellie Bly up to 1905 was said to be $\$ 20,000$ in copper, silver, and gold. The ratio of silver to copper was about 1 ounce of the former to each 20 pounds, or 1 percent, of the latter.

The Lee mive was said to be over 200 feet deep; but water stood up to the 70 -foot level. A prorluction of $\$ 110,000$ is said to have been derived from lowgrade copper-silver ore, mostly through the operation of a Huntington mill, during the years $1894-98$.

Plate 25 shows the workings of the Nellie Bly mine as developed in July 1908. It shows also the quartz latite dike as cut on the different levels. Nothing definite is known of the relation between dike and vein, but identical quartz latite dikes are known to be later than the main stages of mineralization in the Virginia area to the north. The silver-copper ratio at the Nellie Bly, as given by Graton, is similar to this ratio in the average supergene ore mined at the Eighty-five and Bonney mines in the Virginia district.

Both the Nellie Bly and Robert E. Lee mines have been worked at intervals since 1905 and in the aggregate must have produced considerable ore.

${ }^{30}$ Presumably tarnished chalcopyrite; the only bornite seen anywhere in the Lordsburg district is supergene material in microscopic amounts.-S. G. L. 


\section{INDEX}

Aberdeen Peak, basalt near._._._._... bedded breccia on..............

Abstract

Acknowledgments for aid_._._._._.

Alamo mine. See Atwood nnine.

Analyses of mine waters_._._._...

Anita-Atwood group of veins, typical quartz outcrops of _-_ $29, \mathrm{pl} .6$

Anita-Atwood zone of faults. $29,0 l .6$
$20-22$
-51

Anita mine, general features of ..... geologic sections of _._._._._. pl. 21 geology and ore deposits of _._. $51-53$. pls. $3,5,20,21$

ore of pls. $3,5,20,21$ plan and projection of _._._._._- pl. 20 water pumped from.

Aplite dikes, occurrence of Assimilation of basalt by granodiorite, occurrence of

Atwood Fill, plug of volcanic breccia forming _... 13,18

Atwood mine, general features of _... geologic plan and section of ..... pl. 22 geology and ore deposits of _._. 53-54,

pl. 22

ore of

water pumped from

54

Basalt, occurrence and character of -- 11-13 Bibliography -_._. Bonney mine, altered rock from_..- 38 ,

pls. 10,11

future prospecting in _._.____- 50-51 geologic plan of fifth level of _.- pl. 19 geologic sections of _._._._._. pl. 18 geology and ore deposits of -.-- 49-50,

.. ... pls. 17-1

history and production of

location of

48, pl. 14

ore of, character of distribution of grade of plan and projection of _..._._... pl.17 water pumped from__.___._. 8,9 workings of

Calumet \& Arizona Mining Co., ownership of Eighty-five mine by 27,42

Claims, map showing

pl. 14

Climate_.. 6-7

Comanche time, events of .........-

Cooperation

Copper, production of

Cretaceous period, volcanic activity during

Cretaceous rocks, occurrence and char acter of $10-16$

Dikes, occurrence and character of -- 15-16 lage

D: usy breccia ore, occulrence and charicter of _..._ $30-32, \mathrm{pl} .8$

Eighty-five mine, analyses of water from_-_._._. 9

general features of

geologic plans of 650 -foot, 1,050 foot, a nd 1,500-foot levels of

geologic relations at pls. $5,13,15,16$ geologic sections through__._._- pl. 16 history of _....... 27 location of _........... 44, pl. 1.4 ore deposits of _._._. $45-46$, pls. $13,1.5$ continuation of, bey ond

.... known limits....... 46-4S ore of, character of $-38,42$, pls. $8,9,12$ grade of _._.

production costs at._.......... 43 shutdown of _._._._._..... 27, 42

temperature and humidity in vertical projection and longitudinal section of _._._. p1.13

water pumped from workings of _..._._._._. 44, pl. 13 limerald vein, details of _._._._. 31 displacement along distribution of vein matter in_._ $\quad 22$ Eighty-flve mine on_.......... 44 extent of mining on_._._._._... 29 production from_._. 28 quartz latite dike cutting supergene alteration along_-- 41, pl. 13 traceable length of Enrichment of ores, occurrence and character of _._- $41-42 \mathrm{pl} .1 .3$

Faults, character of $\ldots \ldots \ldots$ 20-21 direction änd amount of dip of - 20-21. movement along _._. 22 relation of, to g a a n o d i o r i t c stock____._. 20,23-24, pl, 5 to period of ore formation - 20-21 zones of

Felsite dikes, occurrence and character of

Florence May-Lone Star-Summit vein, features of _._._. 29, pl. 7

Geography__._. $5-9$

Geologic maps _..._._._._. pls. 1, 3

Geologic history, interpretation of

Geologic sections _._._._._._. pls. 1, 3

Geology _.._.

Gilbert, G. K., quoted _._......... 25

Gold, production of - 28

Granodiorite, a l t e r e d, photomicrograph of _... pl. 11

porphyritic, occurrence and character of 
Page

Granodiorite stock, relations of - 19-20, pl. 5 Graton, L. C., quoted_______ 58-60 Green Copper claim, rhyolite interbedded with breccia on

Green King mine, rhyolite at....-. Ground water. See Water, underground.

Henry Clay mine, general features of - 54-55 Hydrothermal leaching, occurrence and $\quad$ c haracter of _._...... $37-40$, pls. 8-12

Intrusive rocks 13-14

Last Chance mine, general features of -

ore of

plan and vertical projection of -- pl. 24

Lead, production of

Lee Peak, reins at__._._____ 29, pl. 7

Leitendorf camp, general features of -

history and production of

Leitendorf Hills, Miocene( ?) rocks of_-

Leitendorf mine. See Venus mine.

Lena mine. See Misers Chest mine.

Location of the district._._-_._-_.

Lone Star vein, features of

Lordsburg district, aerial photograph of main part of

claim map of _._-____-_geologic map and sections of--mine production of

Magdalena limestone, occurrence of -Mineralization, first stage of, features or-_-_ $34-35$, pls. 8,11 fourth and fifth stages of, features of _-_._._._._. $40-41$

general features of stages of _._. 31-33 second stage of, features of _ $35-37, \mathrm{pl} .8$ sixth stage of, features of _._. 41 . third stage of, features of --- $40, \mathrm{pl} .12$

Mines, general features of water pumped from

Mine waters, analyses of

Mining, future of

history of

Miocene (?) rocks, occurrence and character of _._._. 10, 16-17

Miocene (?) time, events of

Misers Chest mine, general features of

geologic level maps of

Nellie Bly mine, general features of $59-60$,

plan and section of

New Mexico Bureau of Mines and Mineral Resources, cooperation with_..-_-_.-

Ore, content of average primary ... list of claims shipping mine production of _._._._-_.

Ore deposits, form and structure of general features of
Ore shoots, mineral composition of _-_

Ore, specimens of _._._-_._- pls. 8-10, 12

Otero, M. A., quoted_._._._._._. 26

Oxidation and enrichment of ores, occurrence and character of _-_-_-_- 41-42, pl. 13

Parke, J. G., explorations by__._... 25

Pennsylvanian rocks, occurrence of

Fhelps Dodge Corporation, acquisition of Eighty-five mine by

Pleistocene deposits, character of --- 10

Production, costs of history of _._.

Pyramid district, general features of - $\quad 56$ geology and ore deposits of _... 57-58 See also Leitendorf camp.

Pyramid Mountains, general features of geologic map and sections of north end of.........-

Miocene (?) rocks of

Quartz latite dikes, occurrence and character of

Ralston camp, history of Rlyyolite breccia, steeply dipping bedded__.._______ 14, pl. 4

Rhyolite, intrusive, occurrence and character of

volcanic necks of

Robert E. Lee mine, general features of -

Rocks of the district, attitude of general sequence and age of

Scope of report._... $2-3$ Shakespeare camp, history of _..... 26-27 Silver, production of Structure__. Summit vein, features of._... 29, pl. 7 Surface water, lack of

Tertiary rocks, character of._._._ 10, 14-16

Tertiary time, events of

Topography _... $7-8$

Vegetation_............ 6

Vein flling, general features of ...- 30-34

Veins, post-ore faulting along _-_.- $\quad \mathbf{3 0}$ quartz outcrops of _._.__ 29, pls. 6, 7

Venus mine, general features of --_-- 58 ore of

Viola mine. See Venus mine.

Volcanic breccias, occurrence and character of

Volcanic rocks, earlier (Lower Cretaceous) later (Miocene?) -..-_-_-_-_-_-16-17

34 Water, mine, analyses of

29 surface, lack of

28 underground $8-9$ 